University of Nebraska - Lincoln

DigitalCommons@University of Nebraska - Lincoln

$1-23-2018$

\title{
Origin of last-glacial loess in the western Yukon-Tanana Upland, central Alaska, USA
}

Daniel R. Muhs

Jeffrey S. Pigati

James R. Budahn

Gary L. Skipp

E Arthur Bettis III

See next page for additional authors

Follow this and additional works at: https://digitalcommons.unl.edu/usgsstaffpub

Part of the Geology Commons, Oceanography and Atmospheric Sciences and Meteorology Commons, Other Earth Sciences Commons, and the Other Environmental Sciences Commons

This Article is brought to you for free and open access by the US Geological Survey at DigitalCommons@University of Nebraska - Lincoln. It has been accepted for inclusion in USGS Staff -- Published Research by an authorized administrator of DigitalCommons@University of Nebraska - Lincoln. 
Authors

Daniel R. Muhs, Jeffrey S. Pigati, James R. Budahn, Gary L. Skipp, E Arthur Bettis III, and Britta Jensen 


\title{
Origin of last-glacial loess in the western Yukon-Tanana Upland, central Alaska, USA
}

Daniel R. Muhs ${ }^{\mathrm{a}, *}$, Jeffrey S. Pigati ${ }^{\mathrm{a}}$, James R. Budahn ${ }^{\mathrm{a}}$, Gary L. Skipp ${ }^{\mathrm{a}}$, E. Arthur Bettis, III ${ }^{\mathrm{b}}$, Britta Jensen ${ }^{\mathrm{c}}$

${ }^{a}$ U.S. Geological Survey, MS 980, Box 25046, Federal Center, Denver, Colorado 80225, USA

${ }^{\mathrm{b}}$ Department of Earth and Environmental Sciences, University of Iowa, Iowa City, Iowa 5224, USA

${ }^{\mathrm{c}}$ Department of Earth Sciences, University of Alberta, Edmonton, Alberta T6G 2E3, Canada

(RECEIVED May 3, 2017; AcCEPTED January 23, 2018)

\begin{abstract}
Loess is widespread over Alaska, and its accumulation has traditionally been associated with glacial periods. Surprisingly, loess deposits securely dated to the last glacial period are rare in Alaska, and paleowind reconstructions for this time period are limited to inferences from dune orientations. We report a rare occurrence of loess deposits dating to the last glacial period, $\sim 19 \mathrm{ka}$ to $\sim 12 \mathrm{ka}$, in the Yukon-Tanana Upland. Loess in this area is very coarse grained (abundant coarse silt), with decreases in particle size moving south of the Yukon River, implying that the drainage basin of this river was the main source. Geochemical data show, however, that the Tanana River valley to the south is also a likely distal source. The occurrence of last-glacial loess with sources to both the south and north is explained by both regional, synoptic-scale winds from the northeast and opposing katabatic winds that could have developed from expanded glaciers in both the Brooks Range to the north and the Alaska Range to the south. Based on a comparison with recent climate modeling for the last glacial period, seasonality of dust transport may also have played a role in bringing about contributions from both northern and southern sources.
\end{abstract}

Keywords: Loess; Alaska; Last glacial period; Mineralogy; Geochemistry; Provenance; Paleowinds

\section{INTRODUCTION}

Loess is one of the most widespread Quaternary deposits of North America (Fig. 1a). It is commonly the uppermost surficial deposit in much of the central part of North America, particularly in the Great Plains and greater Mississippi River valley regions. In addition, loess is extensive over much of Alaska and adjacent parts of Yukon Territory in Canada (Fig. 1b). In some parts of central Alaska, loess can be several tens of meters thick and, based on a combined volcanic ash and paleomagnetic record, may date back as far as $\sim 3 \mathrm{Ma}$ (Westgate et al., 1990).

In the glaciated portion of central North America, by far the most extensive and thickest loess unit of the Quaternary is Peoria Silt, dating to the last glacial period, here considered to be $\sim 30 \mathrm{ka}$ to $\sim 15 \mathrm{ka}$ (all ages herein are in thousands of calibrated years), based on loess chronologies in Grimley et al. (1998), Bettis et al. (2003), Muhs et al. (2013a), and Pigati et al. (2015). This age range of loess accumulation

* Corresponding author at: U.S. Geological Survey, MS 980, Box 25046 , Federal Center, Denver, Colorado 80225, USA. E-mail address: dmuhs @usgs.gov (D.R. Muhs). correlates with the latest portion of Marine Oxygen Isotope Stage (MIS) 3 and most of MIS 2, based on the time scale given in Martinson et al. (1987). Peoria Silt ranges in thickness from less than a meter to up to a few tens of meters. Along the eastern side of the Missouri River in western Iowa, for example, glaciogenic Peoria Silt is $\sim 40 \mathrm{~m}$ thick (Muhs and Bettis, 2000). Farther west, and south of the Platte River system in Nebraska, (mostly) nonglaciogenic Peoria Silt is as much as $\sim 47 \mathrm{~m}$ thick (Muhs et al., 2008b). At almost every locality where it is found, Peoria Silt is significantly thicker than the next-oldest loesses (Roxana Silt or Gilman Canyon Formation, 70-60 ka [MIS 4]; and Loveland Silt, $\sim 160-140 \mathrm{ka}$ [MIS 6]). Based on thickness and particle-size trends, paleowinds in the North American midcontinent during the time of Peoria Silt accumulation were dominantly from the west and/or northwest (Muhs and Bettis, 2000).

In Alaska, much less is known about the possible occurrence of last-glacial loess accumulation and paleowinds during this time period. These are the two primary questions that are addressed in the present study. Péwé (1975a, p. 37) stated that most loess in Alaska was deposited during the past two glacial periods, interpreted to mean those time periods that would correlate to MIS 6 (penultimate glacial period) and 
(a)

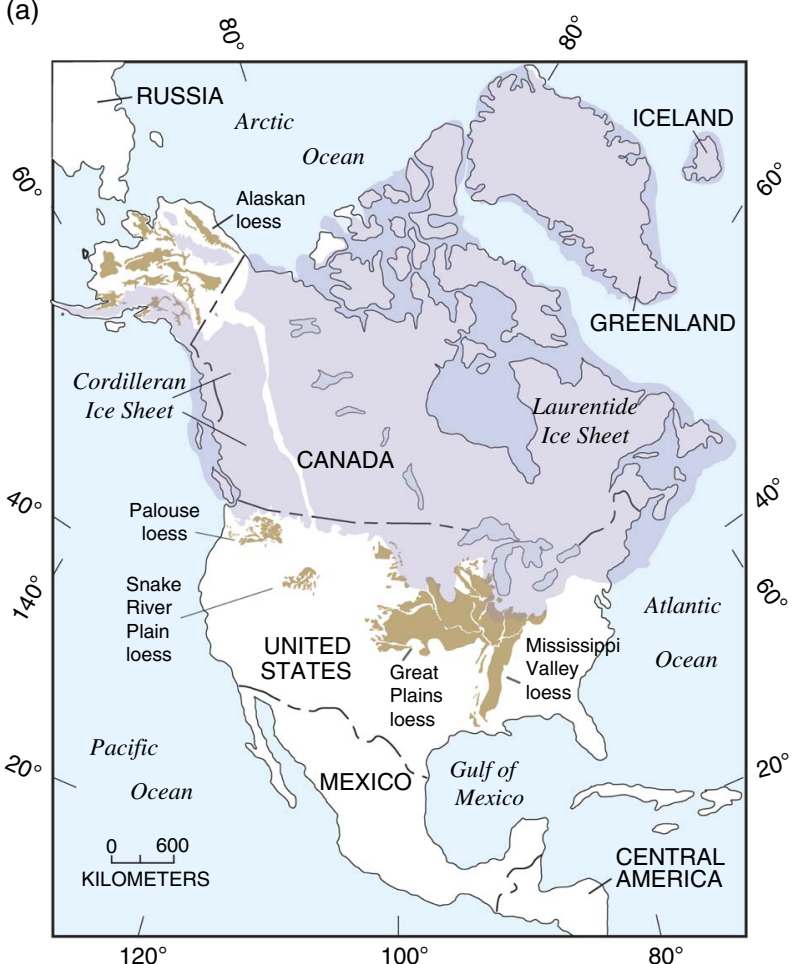

Loess (b)

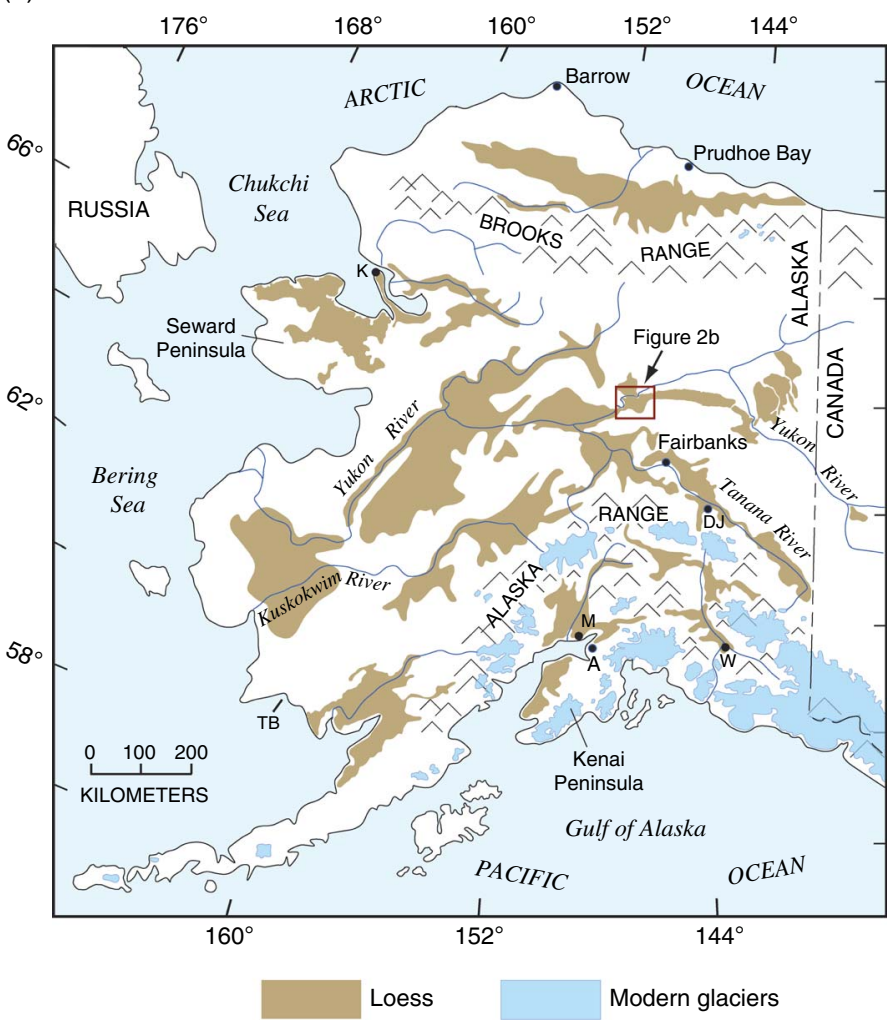

Figure 1. (a) Map showing the distribution of loess (brown) in North America, from Bettis et al. (2003) and sources therein; extent of lastglacial-aged ice (purple) is from Kaufman et al. (2004) for Alaska and Dyke et al. (2002) for all other areas. (b) Map showing the distribution of loess deposits (brown) in Alaska, compiled from Hopkins (1963) and Sainsbury (1972) for the Seward Peninsula; Williams (1962), Foster et al. (1983), and Weber et al. (1997) for areas along the Yukon River; and Péwé (1975a) for all other parts of the region. Most mapping from these sources has been field checked by the authors. Also shown is the present extent of glaciers (blue) in the region, taken from Péwé (1975a) and Brown et al. (1997). The red box in panel b outlines the study area. Abbreviations for other localities: A, Anchorage; DJ, Delta Junction; K, Kotzebue; M, Matanuska Valley area; TB, Togiak Bay; W, Wrangell-St. Elias National Park. (For interpretation of the references to color in this figure legend, the reader is referred to the web version of this article.)

MIS 4, 3, and 2 (last glacial period, sensu lato), respectively. In contrast to central North America, however, loess deposits in Alaska that have been securely dated to the last glacial period are rare. Those that have been identified are only thin accumulations, for the most part. For example, on the Seward Peninsula (Fig. 1b), loess blankets a land surface with fossil tundra vegetation that is well dated to the last glacial period (Höfle and Ping, 1996; Höfle et al., 2000), but the deposit is less than a meter thick. South of this locality, along Norton Sound (Fig. 1b), eolian silt dating to the last glacial period is found in a maar lake deposit (Muhs et al., 2003a), but loess adjacent to this lake is thin. In the Fox Permafrost Tunnel near Fairbanks, silt that could be reworked loess is $6-7 \mathrm{~m}$ thick and is bracketed by radiocarbon ages of $\sim 9.5 \mathrm{ka}$ (above) and $\sim 34 \mathrm{ka}$ (below) and therefore could date to the last glacial period (Hamilton et al., 1988). However, there are radiocarbon age inconsistencies in the section, and whether the silt is truly eolian is not certain. Not far from the Fox Permafrost Tunnel, at an upland site, loess is dated to between $\sim 36 \mathrm{ka}$ and $\sim 12 \mathrm{ka}$ but is less than a meter thick (Muhs et al., 2003b). Elsewhere near Fairbanks, attempts to date loess have been frustrated by uncertain luminescence geochronology or a lack of materials suitable for radiocarbon analyses (Oches et al., 1998; Berger, 2003; Muhs et al., 2003b). Recent identification of Dawson tephra deposits $(\sim 30 \mathrm{ka})$ in the upper part of loess deposits near Fairbanks permits an inference of as much as $\sim 3 \mathrm{~m}$ of loess accumulation since the time of ash deposition (Jensen et al., 2016). It is not known, however, how much of this sediment is of last glacial age and how much is of Holocene age. In the Delta Junction area of central Alaska, loess has been dated only to the Holocene (Péwé, 1975a; Muhs et al., 2003b). On the Kenai Peninsula of southern Alaska, Lethe tephra deposits dating to $\sim 19 \mathrm{ka}$ to $\sim 15 \mathrm{ka}$ are found below or in the lower part of loess, but as on the Seward Peninsula, this eolian silt is less than a meter thick (Reger et al., 1996). Elsewhere in southern Alaska, near Anchorage, loess of the Matanuska Valley all dates to the Holocene (Muhs et al., 2004, 2016a), as does loess in Wrangell-St. Elias National Park, to the east (Muhs et al., 2013a). Many of the youngest loess deposits in northern Alaska (north of the Brooks Range), in southwestern Alaska, and along much of the Yukon River (Fig. 1b), however, are either poorly dated or not dated at all. 
In contrasting the thick last-glacial Peoria Silt deposits of the midcontinent with the meager record of last-glacial loess in Alaska, Muhs et al. (2003b) offered the hypothesis that the role of vegetation in trapping dust could be a significant factor in loess accumulation. Tsoar and Pye (1987) note that deposition of suspended dust (i.e., loess accumulation) occurs when (1) there is a reduction in wind velocity, (2) dust particles are washed out in rain, or (3) particles in suspension are trapped by roughness elements. Regarding mechanism 3, Tsoar and Pye (1987) point out that surface roughness heights increase dramatically with increasing vegetation height. Thus, roughness heights increase from bare sand to grassland (steppe or tundra vegetation) to forest. Indeed, roughness heights are more than an order of magnitude greater for forest compared with grass, and by analogy, herb tundra.

Set in this context, the lack of last-glacial loess in the stratigraphic record of central Alaska might be explained by a sparse, herb tundra vegetation with low dust-trapping capability at that time. The presence of a last-glacial-aged, herb tundra community is well documented for interior Alaska from many pollen and macrofossil studies (Ager and Brubaker, 1985; Edwards and Brubaker, 1986; Anderson et al., 1988; Anderson and Brubaker, 1994; Edwards and Barker, 1994; Edwards et al., 2000, 2001, 2016; Bigelow and Edwards, 2001; Ager, 2003; Bigelow et al., 2003; Carlson and Finney, 2004; Tinner et al., 2006). In adjacent Yukon Territory, evidence from plant macrofossils and pollen indicates that well-drained sites hosted a steppe-tundra vegetation at $\sim 30 \mathrm{ka}$ (Zazula et al., 2005) and a xeric steppe and/or steppe-tundra during the last glacial period (Zazula et al., 2006). In contrast, in central North America, the presence of last-glacial-aged boreal forest (see reviews in Baker and Waln, 1985; Wells and Stewart, 1987; Roberts et al., 2003) likely enhanced the potential for loess accumulation and may offer part of the explanation for the extraordinary Peoria Silt thicknesses in the Great Plains and Mississippi River valley regions.

In a recent study, Jensen et al. (2016) evaluated the hypothesis of vegetation control on the degree of loess accumulation outlined by Muhs et al. (2003b). Jensen et al. (2016) point out that there is evidence for significant loess accumulation in central Alaska during earlier glacial periods (MIS 4 and MIS 6), presumably when an herb tundra vegetation also existed across Alaska. Furthermore, these investigators noted that in the middle Pleistocene and early Pleistocene, glaciations were much more extensive in Alaska than during the last glacial period (Kaufman et al., 2004), which could have enhanced the supply of glaciogenic silt available for loess accumulation. The data in Jensen et al. (2016) confirm that the geologic record of last-glacial loess accumulation at a well-studied site (Halfway House) in central Alaska is modest.

In the present study, we report new data on a loess body, south of the Yukon River in central Alaska (Figs. 1b and 2), that has not received much attention. Extensive loess has been mapped previously in this area (Williams, 1962; Péwé, 1975a; Foster et al., 1983; Weber et al., 1997), but not studied in detail. In this area, the Yukon River valley bottom (Fig. 2a) is referred to as "Yukon Flats." The loess body studied here (Fig. 2b) is situated along the lowermost slopes of the YukonTanana Upland that borders Yukon Flats, which we refer to as "Yukon-Tanana Upland loess." We note, however, that this loess body is part of a larger, nearly contiguous loess body that continues across the Yukon Flats area (Fig. 2a).

Along the Yukon River in central Alaska, the older part of the loess record has been studied in detail at only a couple of localities (Begét et al., 1991; McDowell and Edwards, 2001; Matheus et al., 2003; Reyes et al., 2010a, 2010b, 2011; Jensen et al., 2013). These studies focused on the early and middle Pleistocene record, and the question of last-glacialaged loess was not addressed. Nevertheless, along the middle reaches of the Yukon River in Alaska, Froese et al. (2005) reported a number of localities where maximum-limiting ages of $\sim 14-12 \mathrm{ka}$ were obtained below several meters of eolian sand, and one locality yielded ages of $\sim 11.2-10.5 \mathrm{ka}$ in the middle of a section that exposes $\sim 14 \mathrm{~m}$ of loess. Thus, the study of Froese et al. (2005) indicates that last-glacial-aged loess may exist in the region. Here, we report new stratigraphic, geochronological, mineralogical, sedimentologic, and geochemical data from loess exposed in the YukonTanana Upland and Yukon Flats areas.

Investigation of the loess deposits in the Yukon-Tanana Upland and Yukon Flats areas allows us to test two hypotheses. One is that significant amounts of last-glacial-aged (MIS 2) loess may exist in central Alaska, which has implications for the proposal of Muhs et al. (2003b) that the type of dominant vegetation exerts a strong control on the amount of loess accumulation in this region. If this hypothesis is confirmed, then a second hypothesis to test is the reconstruction of last-glacial paleowinds from the northeast for interior Alaska, proposed by Hopkins (1982) and Lea and Waythomas (1990), based on locations of dune fields and orientations of dunes within those sand bodies. Testing of this hypothesis requires identification of the source or sources of loess in the study area.

\section{METHODS}

Soils, paleosols, and loess sediments were measured and described in the field using standard terminology as practiced in the United States (Birkeland, 1999; Schoeneberger et al., 2012). Materials collected for radiocarbon dating include land snails and plant macrofossils from peaty deposits within the loess. Land snails used for dating are all in the Succineidae family, which Pigati et al. (2010, 2013) have demonstrated yields reliable radiocarbon ages. Plant remains from peats found in loess were pretreated according to methods described by McGeehin et al. (2001). All radiocarbon ages were calibrated to calendar ages using the IntCal13 data set and CALIB 7.1 program (Stuiver and Reimer, 1993; Reimer et al., 2013). Ages from this study are presented in thousands of calibrated years before present ( $\mathrm{yr} \mathrm{BP} ; 0 \mathrm{yr} \mathrm{BP}=\mathrm{AD} 1950$; 
$\mathrm{ka}=$ thousands of calibrated ${ }^{14} \mathrm{C}$ yr BP), and uncertainties are given at the $95 \%(2 \sigma)$ confidence level (Table 1$)$.

Tephra layers are sometimes found in Alaskan loess deposits, and two were found in an exposure in the present study. For tephra analyses, samples were sieved into multiple size fractions, and those with the most abundant glass were utilized for analysis. For the samples collected in this study, the size fraction used was $45-75 \mu \mathrm{m}$. Details on preparation methods can be found in Jensen et al. (2008, 2011). Majorelement geochemistry was determined on single glass shards with a JEOL 8900 superprobe at the University of Alberta microprobe laboratory using a $15 \mathrm{KeV}$ voltage, $10 \mu \mathrm{m}$ beam diameter, and $6 \mathrm{nA}$ current. A sample of Lipari obsidian (ID 3506) and a sample of the Old Crow ash were run concurrently with all unknown samples to ensure proper calibration and allow accurate comparison between samples run at different times.

For particle-size analyses of loess, soils, and paleosols, samples were pretreated with hydrogen peroxide $(30 \%)$ to remove organic matter, acetic acid to remove carbonates, and sodium hexametaphosphate to enhance dispersion. Sands (particles with diameters $>53 \mu \mathrm{m}$ ) were separated from silts and clays by wet sieving; abundances of coarse silts $(53-20 \mu \mathrm{m})$, fine silts $(20-2 \mu \mathrm{m})$, and clays $(<2 \mu \mathrm{m})$ were determined by settling and pipette analysis. Laboratory precision for pipette analysis was routinely monitored with each suite of sample runs by analysis of a well-characterized, internal loess standard.

For bulk mineralogy, samples were pulverized and analyzed as random mounts by X-ray diffractometry (XRD). For clay mineralogy, samples were first pretreated by removal of organic matter with hydrogen peroxide and removal of carbonates with acetic acid, followed by addition of a sodium hexametaphosphate dispersant. Clays were isolated by settling and suspension and then mounted on glass slides by suction, using the Millipore filter method. Clay slides were X-rayed three times: air dry, after glycolation, and after heating at $550^{\circ} \mathrm{C}$ for 1 hour. Methods for clay mineral identification follow Moore and Reynolds (1989).

Assessment of the abundance of dominant minerals and determination of the degree of chemical weathering in loess sections were conducted using both bulk mineralogy (semiquantitative, from XRD analyses described previously) and quantitatively using major element concentrations that proxy for the dominant minerals. These chemical proxies include $\mathrm{CaO}$ for calcite and dolomite, $\mathrm{Na}_{2} \mathrm{O}$ for plagioclase, and $\mathrm{K}_{2} \mathrm{O}$ for K-feldspar and mica. Assessment of the degree of chemical weathering was conducted by calculation of chemical weathering ratios, normalizing the major oxides in primary minerals to an insoluble element $(\mathrm{Zr})$ in a resistant mineral (zircon). The resultant calculations are indexes of the degree of depletion of calcite and dolomite $\left(\mathrm{CaO} / \mathrm{ZrO}_{2}\right)$, plagioclase $\left(\mathrm{Na}_{2} \mathrm{O} / \mathrm{ZrO}_{2}\right)$, and mica and $\mathrm{K}$-feldspar $\left(\mathrm{K}_{2} \mathrm{O} / \mathrm{ZrO}_{2}\right)$. For selected samples, estimates of calcite content using $\mathrm{CaO}$ abundances and XRD results were compared with measurements of $\mathrm{CaCO}_{3}$ content following gas evolution after dissolution with $\mathrm{HCl}$ (Dreimanis, 1962).
For assessment of possible loess sources, we use ratios of certain trace elements that were identified by Muhs and Budahn (2006) as distinctive for silts in the major river systems of the region. These include the following ratios, all of which utilize trace elements with a minimum degree of mobility in near-surface environments (Taylor and McLennan, 1985; McLennan, 1989): Cr/Sc, Th/Ta, As/Sb, and Zr/ Hf. We also use two sensitive indicators of rare earth element (REE) composition, $\mathrm{Eu} / \mathrm{Eu}^{*}$ and $\mathrm{La}_{\mathrm{N}} / \mathrm{Yb}_{\mathrm{N}}$, where the "N" subscript indicates the element is normalized, by convention, to chondrite values (see Muhs and Budahn [2006] for examples of how these values are used in provenance determinations). Finally, major and trace element ratios in the $\mathrm{K}$-bearing minerals, mica and K-feldspar, also provide useful provenance indicators, at least in unaltered loess (Muhs et al., 2016b). For these, we recognize that $\mathrm{K}$ and the trace elements that follow it (Ba, $\mathrm{Rb}$, and $\mathrm{Cs})$ can potentially be mobile in near-surface environments, but for deep loess, well below the land surface, there is likely very limited leaching of these elements from K-bearing minerals. For both loess and possible sources from river silts, abundances of major and trace elements were determined by instrumental neutron activation analysis, following methods in Budahn and Wandless (2002).

\section{RESULTS}

\section{Stratigraphy and chronology}

Loess was examined in natural exposures and road cuts along or near the Dalton Highway over a 60-km-long transect, from north of the Yukon River to the southeast (Fig. 2b). Along the Dalton Highway, loess is as much as $10 \mathrm{~m}$ or more thick immediately to the south of the Yukon River (locality AK-600B in Fig. 2b) and could be at least that thick several kilometers to the southeast, where bedrock was not reached in sections that expose $\sim 9 \mathrm{~m}$ of loess. These minimum thicknesses are best exposed in our "Main Trench" and "South Trench," excavations (Fig. 3) at localities AK-601A and AK-650A, respectively (Fig. 2b). To the southeast, at localities AK-600E and AK-DHB, bedrock is exposed within a few meters of the surface. Still farther southeast, we did not observe loess on the higher elevations of the Yukon-Tanana Upland (Fig. 2a). In reconnaissance field studies southwest of Circle (Fig. 2a), we observed as much as $\sim 7 \mathrm{~m}$ of loess exposed in road cuts, but exposures typically show $\sim 3 \mathrm{~m}$ of loess.

Loess in the Yukon-Tanana Upland usually exhibits little or no bedding and is a massive silt loam (Figs. 3 and 4). When dry, loess from this area is gray $(2.5 \mathrm{Y} 5 / 1$ or $2.5 \mathrm{Y} 6 / 1)$, light brownish gray $(2.5 \mathrm{Y} 6 / 2)$, or light olive brown (2.5Y 5/3). Horizontal to subhorizontal oxidation streaks with brighter, redder colors, probably attributable to secondary Fe-oxides, are common, particularly in the upper parts of most sections. In some sections, wood fragments or charcoal, along with slightly darker sediment matrix colors $(2.5 \mathrm{Y} 5 / 2$ or $2.5 \mathrm{Y} 4 / 1)$, indicate the likely presence of paleosols, with higher organic matter content. This is 

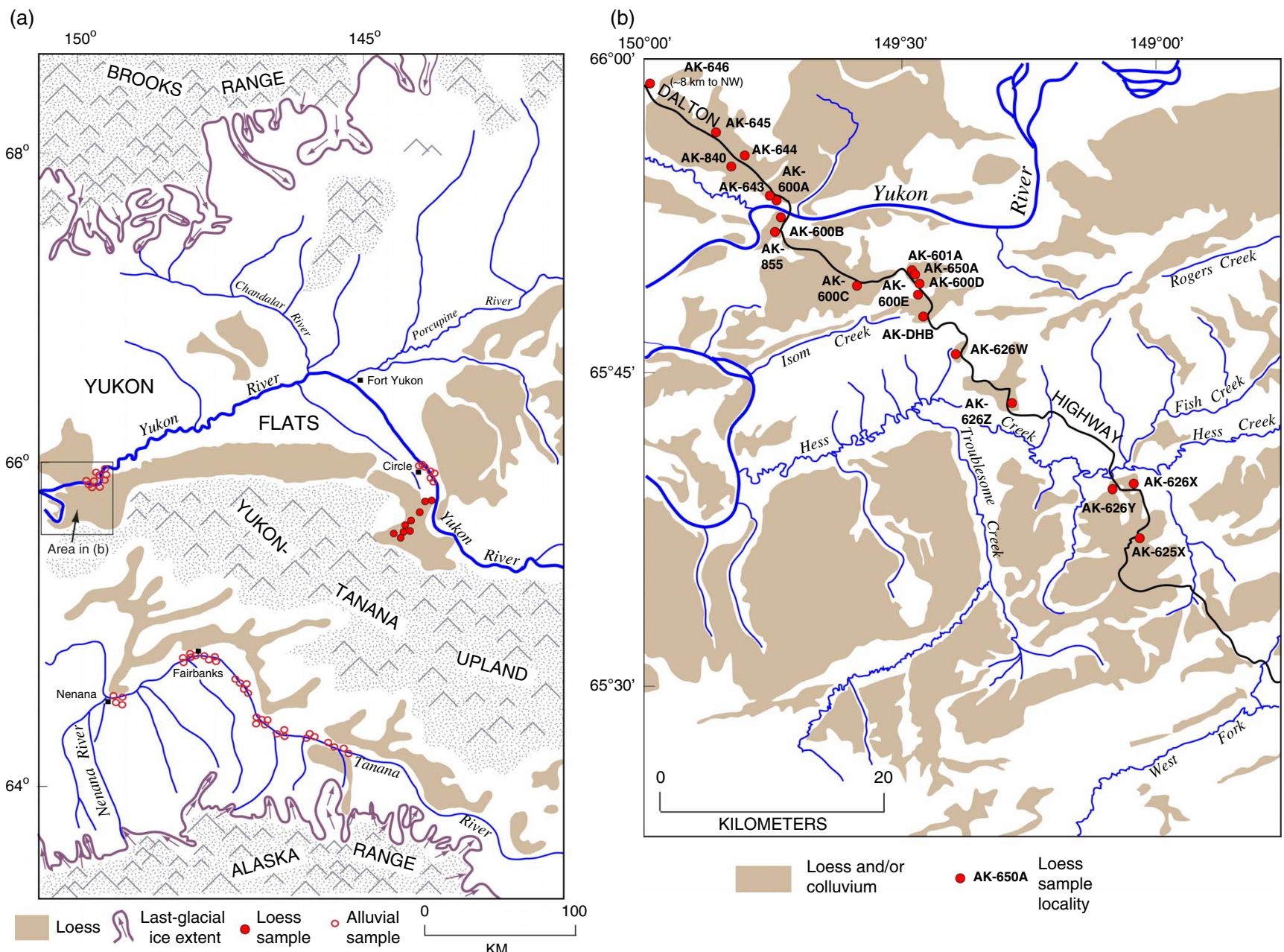

Figure 2. (a) Map showing the distribution of loess in central Alaska, downvalley extent of ice during the last glacial period, major river systems, mountain ranges, and alluvial sample localities (open red dots) along the Tanana and Yukon Rivers (from Muhs and Budahn, 2006). Loess distribution from Williams (1962), Péwé et al. (1966), Péwé (1975a), Foster et al. (1983), and Weber et al. (1997), with minor new mapping by Muhs et al. (2003b). Downvalley extent of last-glacial ice is redrawn in simplified form from Kaufman et al. (2004). (b) Map of loess, colluviated loess, and colluvium (brown shades) and major drainages in the study area near the Dalton Highway Yukon River crossing (see general location in panel a). Filled red dots show loess sections studied. Distribution of loess and colluvium slightly modified from Weber et al. (1997) with minor new mapping by the authors. (For interpretation of the references to color in this figure legend, the reader is referred to the web version of this article.)

particularly evident in the upper part of the South Trench. In this section, what we interpret to be soliflucted paleosols are present, along with horizontal to subhorizontal wood-rich zones $1-3 \mathrm{~cm}$ thick (Fig. 4a). Both above and below the paleosols and wood-rich zones in the South Trench excavation, there are land snails, commonly in clusters (Fig. 4b). The snails are all in the Succineidae family, and they may be Succinea strigata, based on a hypothesized identification of this species in loess of the region by Williams (1962). These land snails were found at almost all the sections studied and form an important basis for the chronology. Thin loess occurs above the snail clusters, and modern soils cap the sections. Peaty zones can are found deeper in both the Main Trench and South Trench exposures (Fig. 4c). Although tephra deposits are often observed in many Alaskan loess sections (see examples in Jensen et al., 2013, 2016), we observed only one section that contains them, locality AK-855 (Fig. 4d and e). Here, tephra deposits are found at a depth of $175-178 \mathrm{~cm}$ (as a layer) and at $220-225 \mathrm{~cm}$ (as a pod).

Radiocarbon dating of land snails forms the primary basis for our chronology of loess deposition, augmented by radiocarbon ages of plant remains from peaty zones in deeper parts of the loess, and tephrochronology at one section. Radiocarbon analyses of plant fragments within the Main Trench (locality AK-601A) gave calibrated ages of $\sim 18.6 \mathrm{ka}$ (AK-689A at $745 \mathrm{~cm}$ depth) and $\sim 17.2 \mathrm{ka}(\mathrm{AK}-691 \mathrm{~A}$ at $632 \mathrm{~cm}$ depth; Fig. 5a). Nearby, at the South Trench (locality AK-650A), peaty material at a depth of $350-375 \mathrm{~cm}$ gave a calibrated radiocarbon age of $\sim 18.2 \mathrm{ka}$ (Fig. 5a, Table 1). All three of these ages are in good stratigraphic agreement with younger ages derived from higher in the sections, discussed subsequently. 
(a) NORTH
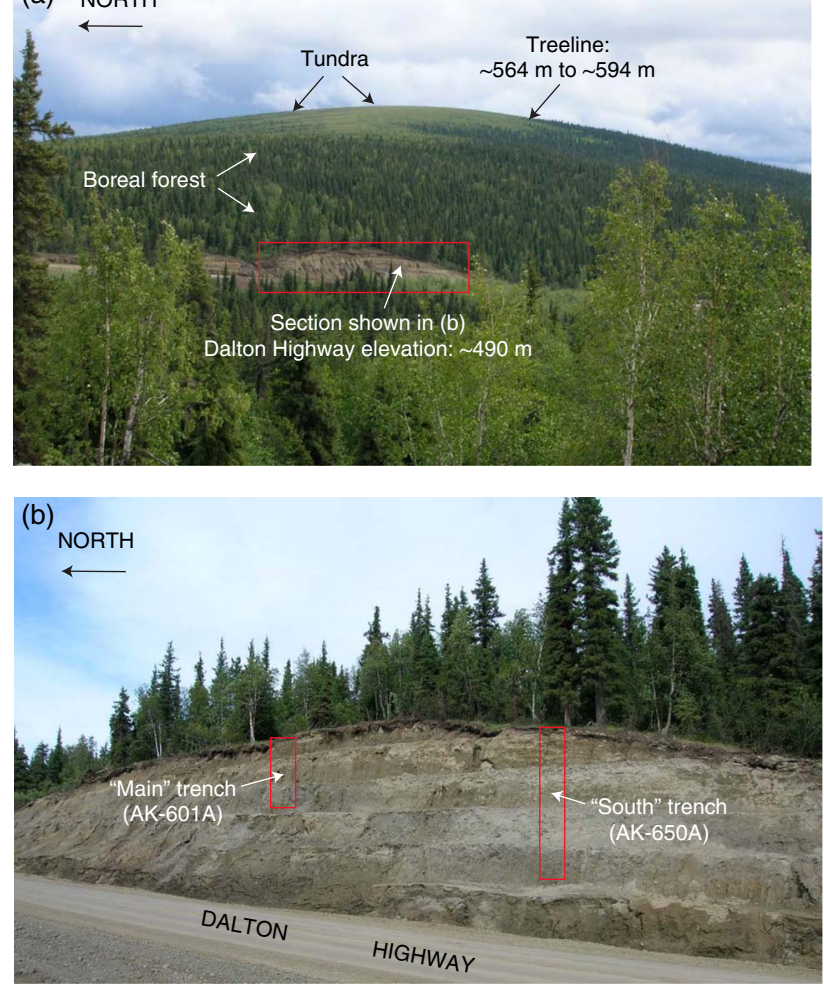

Figure 3. (color online) Photographs of road-cut exposure of loess along the Dalton Highway as it appeared in summer of 2006. (a) Distant view looking east, showing road cut exposure at $\sim 490 \mathrm{~m}$ elevation and its relation to modern treeline. (b) Close-up view of road cut shown in panel a with locations of trenches excavated: "Main Trench" (AK-601A in Fig. 2b) and "South Trench" (AK-650A in Fig. 2b). Note that as of at least 2011, riprap has been placed over the road cut, and very little of the section is still exposed. Photographs by D.R. Muhs.

In loess sections at 12 localities (Figs. 2b and 5a, Table 1), snails were collected from the upper parts of the sections, but below the modern boreal forest soils. The modern soils in the sections have $\mathrm{O}$ or $\mathrm{A} / \mathrm{E} / \mathrm{Bw} / \mathrm{C}$ profiles, similar to the Fairbanks silt loam series mapped in the Fairbanks area (White et al., 2000). The Fairbanks silt loam is a Typic Cryochrept, a common soil type found in upland loess localities under boreal forest in central Alaska. The observation of the snail occurrences below these modern soils is critical, because it means that the snails were living on land surfaces that existed while loess accretion was still taking place. Nevertheless, in no case were snails found at depths below $\sim 2 \mathrm{~m}$, and in most cases, snails were found only within the upper meter of the loess section. Calibrated ages of these snails span a very short interval of time, from $\sim 13.7 \mathrm{ka}$ to $\sim 12.1 \mathrm{ka}$ (Fig. 5a, Table 1). Because analytical uncertainties of calibrated ages of the snails are mostly on the order of $\sim 100$ to $\sim 200 \mathrm{yr}$ (Table 1), many of these ages could, in principle, be interpreted as significantly different from one another. As pointed out by Pigati et al. (2010), however, although many land snails (including Succineidae) are suitable for radiocarbon dating, some of them do incorporate small amounts of inherited, "dead" carbon, a process often referred to as the "limestone effect." Based on Pigati et al.'s (2010) studies of modern shells of the Succineidae family, the limestone effect with these taxa ranges from $<300 \mathrm{yr}$ to $\sim 600 \mathrm{yr}$. Thus, although the strictly analytical uncertainties would permit an interpretation that certain of the snails in loess in this area are younger than others, the much greater possible uncertainty with the limestone effect-though not fatal to dating the deposits-would permit a simpler interpretation that all these snails are of approximately the same age, about $13 \mathrm{ka}$ to $12 \mathrm{ka}$. This may explain the apparent reversals in some snail ages at the South Trench site, where several clusters of snails from different depths and over an approximately $300 \mathrm{~cm}$ horizontal distance were analyzed (Fig. 5b). We interpret the apparent snail age differences from place to place in this trench to be attributable to small but varying amounts of dead carbon uptake by snails in this carbonate-rich loess.

Locality AK-855, situated only about a kilometer south of the Yukon River, is one of our thinner exposures but apparently has one of the oldest records. Tephra deposits were exposed at depths of $\sim 175 \mathrm{~cm}$ (as a bed) and at $\sim 225 \mathrm{~cm}$ (as a pod; see Fig. 4d and e). Considerable effort has been undertaken in the past couple of decades to characterize the Quaternary tephra deposits found in loess and other sediments of Alaska and Yukon Territory (see Preece et al., 1992, 1999, 2011; Froese et al., 2002, 2006; Matheus et al., 2003; Muhs et al., 2003b; Jensen et al., 2008, 2013, 2016). The primary means of correlation is major element geochemistry of glass shards, an approach that is followed here. The upper layer (AK-873 in Fig. 4e) has a mean $\mathrm{SiO}_{2}$ content of $75.32 \pm 0.17 \%$, and the lower pod (AK-878 in Fig. 4e) has a mean $\mathrm{SiO}_{2}$ content of $75.36 \pm 0.17 \%$. When these values are plotted against other major element abundances $\left(\mathrm{Al}_{2} \mathrm{O}_{3}\right.$, $\mathrm{CaO}, \mathrm{FeOt}$, and $\mathrm{K}_{2} \mathrm{O}$ ), the glass shards from this section overlap those of the Old Crow tephra deposits, based on the geochemistry of this ash (Fig. 6) from a key locality at Togiak Bay, in southwestern Alaska (Fig. 1b). Thus, the volcanic ash layer and ash pod at the AK-855 section are likely another occurrence of the Old Crow tephra deposits that are found over much of Alaska and Yukon Territory.

The age of the Old Crow volcanic ash is not known with certainty, but estimates have been made from a variety of techniques and localities, yielding roughly similar ranges. Early isothermal plateau fission track ages range from $156 \pm 26 \mathrm{ka}$ to $118 \pm 23 \mathrm{ka}$ (Westgate, 1988 ; errors are $1 \sigma$ ). Preece et al. (2011) recalculated these ages to range from $148 \pm 43 \mathrm{ka}$ to $113 \pm 22 \mathrm{ka}$. Berger (2003) reported bracketing, partial-bleach thermoluminescence ages of loess of $147 \pm 12 \mathrm{ka}$ (below the Old Crow ash) and $128 \pm 22 \mathrm{ka}$ (above the Old Crow ash). Auclair et al. (2007) reported bracketing infrared stimulated luminescence (IRSL) ages of $135 \mathrm{ka}(+21 /-13 \mathrm{ka}$, below the ash) and $131 \mathrm{ka}(+21 /-13 \mathrm{ka}$, above the ash). Roberts (2012) also conducted IRSL analyses of bracketing loesses around the Old Crow ash and reported that calculated ages are conditioned significantly by preheat temperatures in the laboratory. She therefore generated a suite of possible ages for the Old Crow ash, ranging from 
(a) South Trench, upper part:

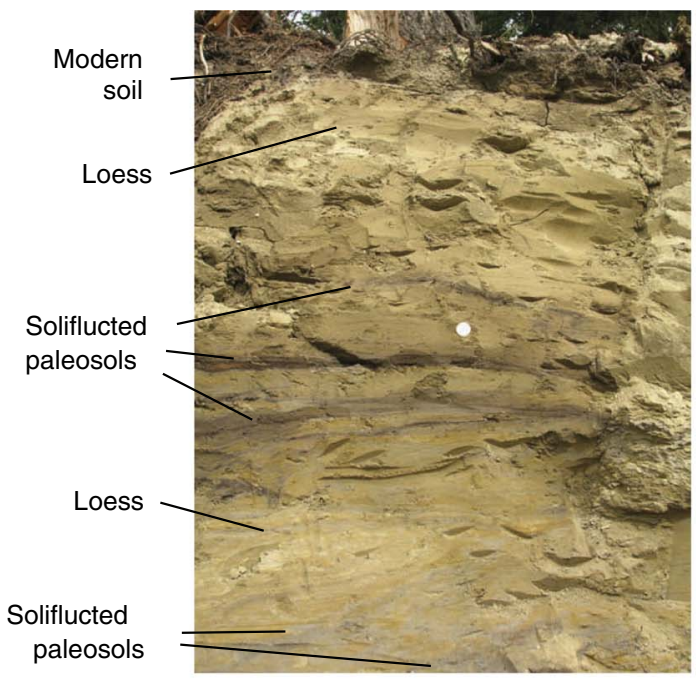

(b) Loess snails, South Trench

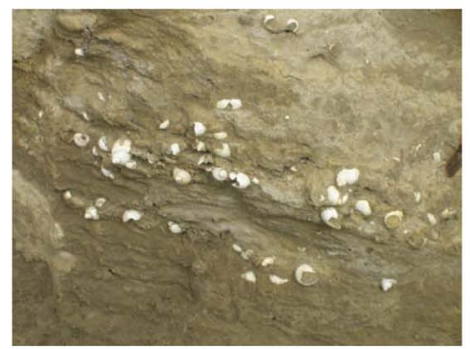

(c)

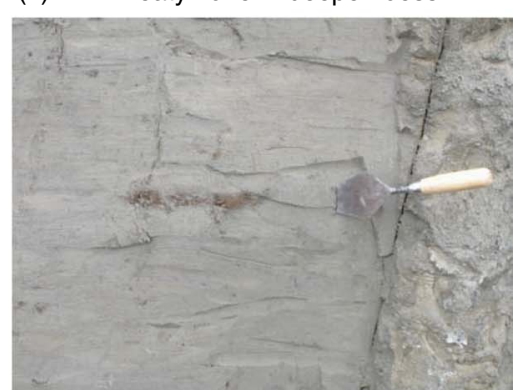

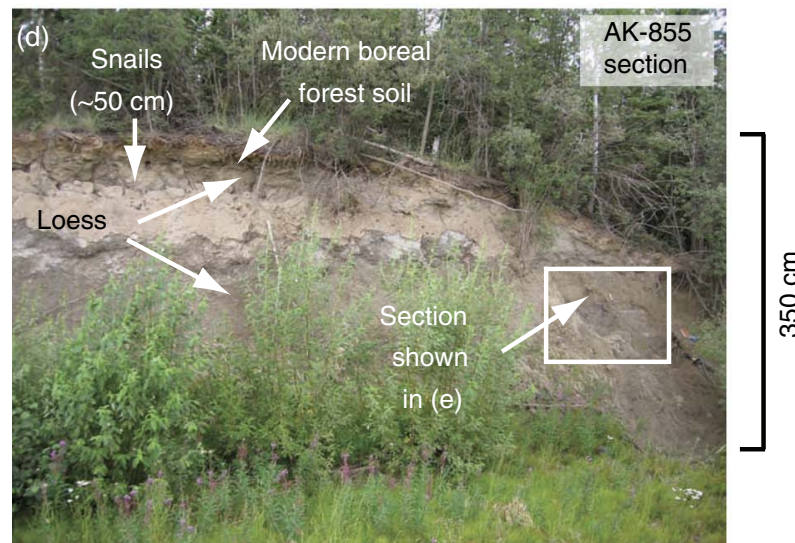

(e)

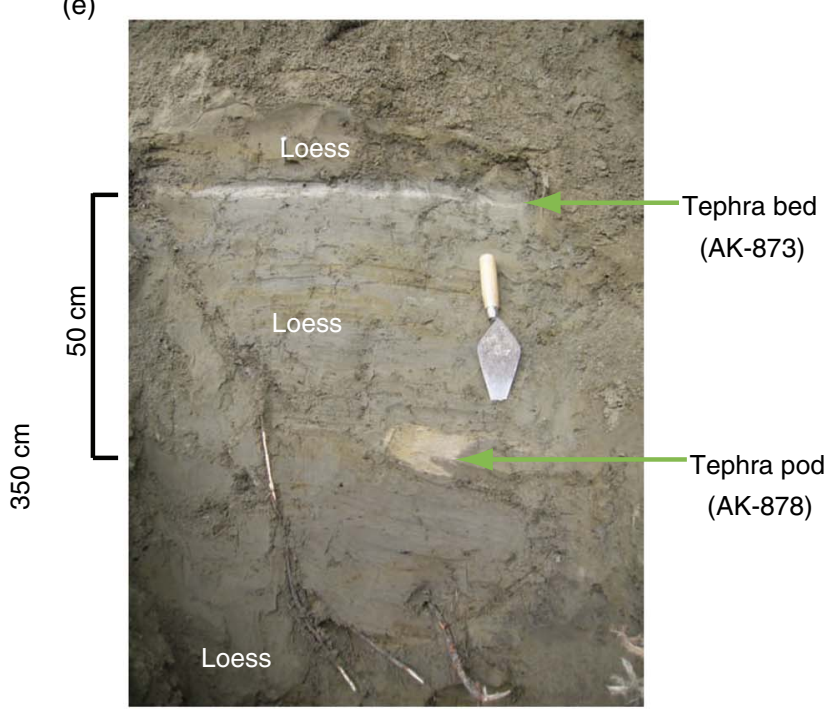

Figure 4. (color online) Photographs showing loess and features within exposures. (a) Loess and paleosols, South Trench; silver circle in the middle of the exposure is a U.S. 25-cent piece with a diameter of $2.3 \mathrm{~cm}$. (b) Land snail cluster, South Trench. (c) Typical peat-rich zone found in deeper parts of loess sections found in Main Trench and South Trench. (d) Long view of AK-855 section showing loess and modern soil; tephra deposits are barely visible in box at right. (e) Close-up view of loess, ash layer, and ash pod in panel d. Photographs by D.R. Muhs.

$\sim 150 \mathrm{ka}$ to $\sim 100 \mathrm{ka}$, using different options for preheat temperatures. Considering all the attempts to date this ash, it is reasonable to say that the Old Crow ash is between $\sim 150 \mathrm{ka}$ and $\sim 100 \mathrm{ka}$ and is likely around $\sim 130 \mathrm{ka}$. If so, then the section at AK-855 contains loess that is much older than at the other sections examined. This older loess, hosting the Old Crow tephra deposits, was likely deposited during the penultimate glacial period, equivalent to MIS 6 . Nevertheless, snail ages near the top of the section (Fig. 5a) indicate that the latest episode of loess deposition was similar in timing to that of the latest deposition at the other sections. Tephra deposits were not found at the other sections (except possibly at section AK-600B, Fig. 5a), and the Old Crow ash, if present at other sections, is presumably stratigraphically below what is exposed. The presence of this ash near the surface at AK-855 implies erosional removal of much of the later (but not latest) part of the loess record at this locality.

\section{Sedimentology}

Loess from the western Yukon-Tanana Upland is dominated by silt-sized particles, consistent with loess deposits worldwide (see examples in Muhs, 2013). In unaltered parts of the sections studied here (i.e., where paleosols are not present), loess has coarse-silt $(53-20 \mu \mathrm{m})$ contents of $55 \%$ to $80 \%$, with loess at many depths having coarse-silt contents of $70 \%$ to $80 \%$ (Fig. 7). Despite the high coarse-silt content, sand $(>53 \mu \mathrm{m})$ content is surprisingly low, usually less than $10 \%$. Coarse-silt/fine-silt values are always greater than 2 , usually greater than 5, and are sometimes higher than 10 (Fig. 7). These values are unusually high for loess deposits, and we discuss the significance of this later.

Both clay-sized particles $(<2 \mu \mathrm{m})$ and fine-silt-sized particles $(20-2 \mu \mathrm{m})$ are enriched in modern soils and paleosols (Fig. 7) similar to loess found in the Fairbanks area (Muhs et al., 2003b). Modern soils have clay contents as high 
(a)
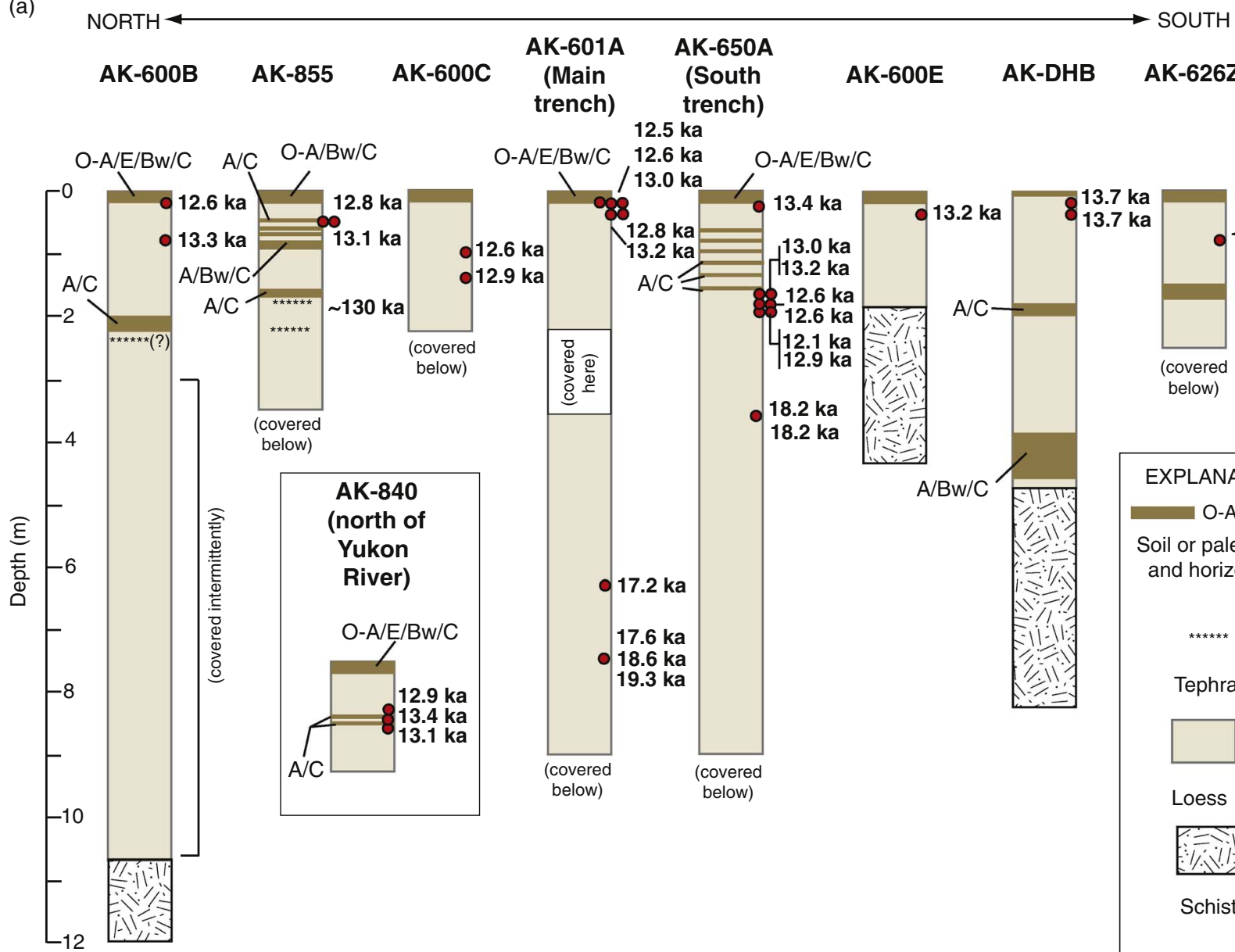

$-A / E / B w / C \quad 12.6$ ka $\quad O-A / E / B w / C$
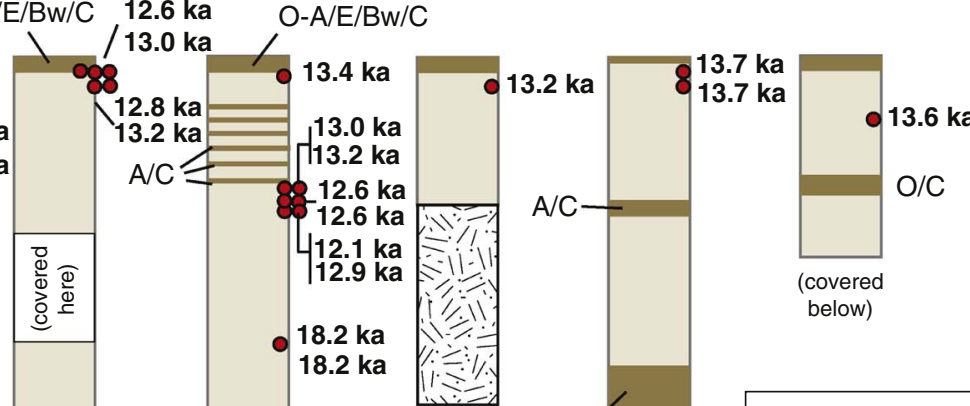

(b)

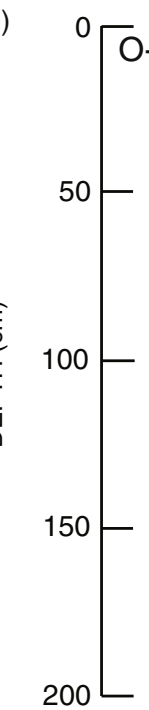

Sample trench

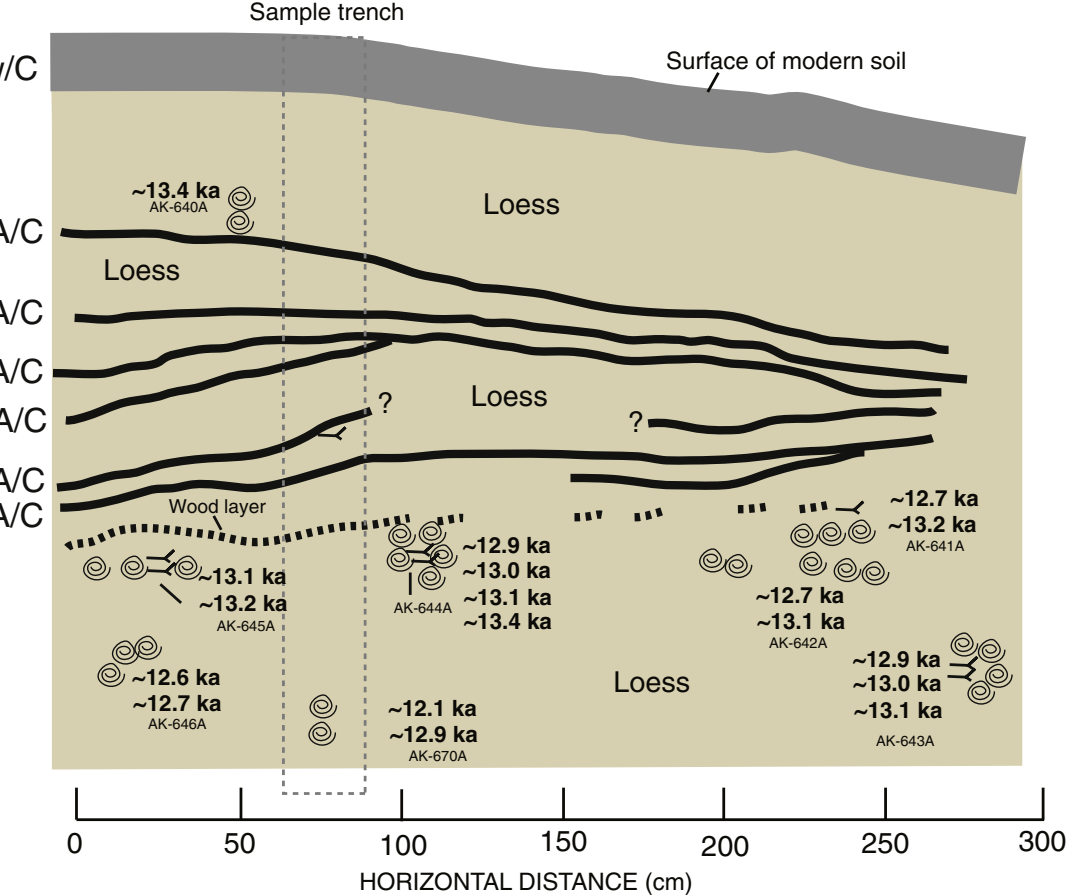

$\prec$ Plant fragments

(2) Snails

Paleosol

Figure 5. (color online) (a) Loess sections studied along the Dalton Highway in the Yukon-Tanana Upland with calibrated radiocarbon ages; locations are shown in Figure 2b, and complete radiocarbon data are given in Table 1. (b) Details of the stratigraphy and calibrated radiocarbon ages of land snails in the upper part of the South Trench (AK-650A; see Fig. 2b for location and Figs. 3 and 4 for photographs). 
Table 1. Summary of sample information and ages for Succineidae shells and plant remains at all sites.

\begin{tabular}{|c|c|c|c|c|c|c|c|c|}
\hline Sample ID & $\mathrm{Lab} \#$ & AMS \# & $\begin{array}{l}\text { Material } \\
\text { dated }\end{array}$ & $\begin{array}{l}\text { Depth } \\
(\mathrm{cm})^{\mathrm{a}}\end{array}$ & $\begin{array}{c}\delta^{13} \mathrm{C} \\
(\mathrm{VPDB})^{\mathrm{b}}\end{array}$ & $\begin{array}{c}{ }^{14} \mathrm{C} \text { age } \\
\left({ }^{14} \mathrm{C} \text { ka BP }\right)\end{array}$ & $\begin{array}{c}\text { Age } \\
(\text { cal ka BP })^{\mathrm{c}}\end{array}$ & $P^{\mathrm{d}}$ \\
\hline \multicolumn{9}{|c|}{ AK-840, Dalton Highway Milepost 60 (north of the Yukon River), $65.92068^{\circ} \mathrm{N}, 149.82870^{\circ} \mathrm{W}$} \\
\hline AK-847 & - & Aeon-2440 & Succineidae & 88 & - & $10.97 \pm 0.16$ & $12.88 \pm 0.26$ & 1.00 \\
\hline AK-849 & - & Aeon-2441 & Succineidae & 95 & - & $11.57 \pm 0.16$ & $13.42 \pm 0.31$ & 1.00 \\
\hline AK-850 & - & Aeon-2442 & Succineidae & 98 & - & $11.23 \pm 0.16$ & $13.06 \pm 0.31$ & 1.00 \\
\hline \multicolumn{9}{|c|}{ AK-600A, Dalton Highway Milepost $56.4,65.89005^{\circ} \mathrm{N}, 149.74361^{\circ} \mathrm{W}$} \\
\hline AK-600A-2 & WW-9217 & CAMS-159984 & Succineidae & 60 & -7.8 & $11.37 \pm 0.03$ & $13.21 \pm 0.08$ & 1.00 \\
\hline \multicolumn{9}{|c|}{ AK-600B, Dalton Highway Milepost $55.5,65.87622^{\circ} \mathrm{N}, 149.72618^{\circ} \mathrm{W}$} \\
\hline YRB-1 & WW-8836 & CAMS-155315 & Succineidae & 20 & -7.9 & $10.66 \pm 0.03$ & $12.63 \pm 0.07$ & 1.00 \\
\hline YRB-5a & WW-8913 & CAMS-156093 & Succineidae & 55 & -8.0 & $11.10 \pm 0.03$ & $12.96 \pm 0.11$ & 1.00 \\
\hline YRB-5b & WW-8914 & CAMS-156094 & Succineidae & 61 & -7.9 & $10.99 \pm 0.03$ & $12.85 \pm 0.12$ & 1.00 \\
\hline YRB-5c & WW-8915 & CAMS-156095 & Succineidae & 63 & -8.2 & $11.05 \pm 0.03$ & $12.91 \pm 0.11$ & 1.00 \\
\hline YRB-5e & WW-8916 & CAMS-156096 & Succineidae & 68 & -8.5 & $11.19 \pm 0.03$ & $13.06 \pm 0.05$ & 1.00 \\
\hline YRB-5f & WW-8917 & CAMS-156097 & Succineidae & 69 & -8.1 & $11.23 \pm 0.03$ & $13.09 \pm 0.04$ & 1.00 \\
\hline YRB-5g & WW-8918 & CAMS-156098 & Succineidae & 72 & -8.2 & $11.41 \pm 0.03$ & $13.24 \pm 0.08$ & 1.00 \\
\hline YRB-4 & WW-8837 & CAMS-155316 & Succineidae & 80 & -7.9 & $11.49 \pm 0.04$ & $13.34 \pm 0.08$ & 1.00 \\
\hline \multicolumn{9}{|c|}{ AK-855, Dalton Highway Milepost 54.7, $65.86615^{\circ} \mathrm{N}, 149.73662^{\circ} \mathrm{W}$} \\
\hline AK-859A & WW-8512 & CAMS-151957 & Succineidae & 47 & -7.1 & $10.94 \pm 0.04$ & $12.81 \pm 0.10$ & 1.00 \\
\hline AK-859 & WW-7285 & CAMS-143294 & Succineidae & 47 & -7.3 & $11.25 \pm 0.05$ & $13.13 \pm 0.08$ & 1.00 \\
\hline \multicolumn{9}{|c|}{ AK-600C, Dalton Highway Milepost $48.6,65.82093^{\circ} \mathrm{N}, 149.57460^{\circ} \mathrm{W}$} \\
\hline AK-600C-1 & WW-9218 & CAMS-159985 & Succineidae & 100 & -7.5 & $10.63 \pm 0.03$ & $12.62 \pm 0.07$ & 1.00 \\
\hline AK-600C-3 & WW-9219 & CAMS-159986 & Succineidae & 140 & -7.3 & $11.02 \pm 0.03$ & $12.89 \pm 0.11$ & 1.00 \\
\hline \multicolumn{9}{|c|}{ AK-601A, Dalton Highway Milepost 45.9, Main Trench, $65.65 .83115^{\circ} \mathrm{N}, 149.49323^{\circ} \mathrm{W}$} \\
\hline AK-604A & WW-8504 & CAMS-151948 & Succineidae & 25 & -7.4 & $10.59 \pm 0.04$ & $\begin{array}{l}12.46 \pm 0.03 \\
12.60 \pm 0.07\end{array}$ & $\begin{array}{l}0.11 \\
0.89\end{array}$ \\
\hline AK-604A & WW-7263 & CAMS-143272 & Succineidae & 25 & -5.6 & $11.10 \pm 0.04$ & $12.95 \pm 0.12$ & 1.00 \\
\hline AK-605A & WW-8505 & CAMS-151949 & Succineidae & 34 & -7.3 & $10.95 \pm 0.03$ & $12.79 \pm 0.07$ & 1.00 \\
\hline AK-605A & WW-7264 & CAMS-143273 & Succineidae & 34 & -6.5 & $11.32 \pm 0.04$ & $13.17 \pm 0.09$ & 1.00 \\
\hline AK-691A & WW-7286 & CAMS-143295 & Plant macros & 632 & -28.5 & $14.11 \pm 0.05$ & $17.18 \pm 0.22$ & 1.00 \\
\hline AK-689A & WW-7283 & CAMS-143292 & Plant macros & 745 & -26.3 & $15.28 \pm 0.05$ & $18.55 \pm 0.15$ & 1.00 \\
\hline AK-689A & - & Aeon-2435 & Humic acids & 745 & - & $14.50 \pm 0.19$ & $17.62 \pm 0.48$ & 1.00 \\
\hline AK-689A & - & Aeon-2434 & Bulk & 745 & - & $16.02 \pm 0.11$ & $19.31 \pm 0.29$ & 1.00 \\
\hline
\end{tabular}

AK-650A, Dalton Highway Milepost 45.9, South Trench, $65.65 .83115^{\circ} \mathrm{N}, 149.49323^{\circ} \mathrm{W}$

\begin{tabular}{|c|c|c|c|c|c|c|c|c|}
\hline AK-640A & WW-7267 & CAMS-143276 & Succineidae & 50 & -6.5 & $11.60 \pm 0.03$ & $13.41 \pm 0.09$ & 0.99 \\
\hline AK-641A & WW-8506 & CAMS-151950 & Succineidae & 145 & -7.7 & $10.73 \pm 0.03$ & $12.68 \pm 0.05$ & 1.00 \\
\hline AK-641A & WW-7268 & CAMS-143277 & Succineidae & 145 & -8 & $11.29 \pm 0.04$ & $13.15 \pm 0.08$ & 1.00 \\
\hline AK-642A & WW-8507 & CAMS-151951 & Succineidae & 150 & -7.7 & $10.80 \pm 0.03$ & $12.71 \pm 0.03$ & 1.00 \\
\hline AK-644A & WW-8509 & CAMS-151953 & Succineidae & 150 & -6.8 & $11.09 \pm 0.03$ & $12.94 \pm 0.12$ & 1.00 \\
\hline AK-644A & WW-7271 & CAMS-143280 & Succineidae & 150 & -6.6 & $11.12 \pm 0.04$ & $12.97 \pm 0.12$ & 1.00 \\
\hline AK-642A & WW-7277 & CAMS-143286 & Succineidae & 150 & -6.3 & $11.22 \pm 0.03$ & $13.09 \pm 0.05$ & 1.00 \\
\hline AK-644AR-3 & WW-9225 & CAMS-159992 & Succineidae & 150 & -6.7 & $11.27 \pm 0.03$ & $13.13 \pm 0.06$ & 1.00 \\
\hline AK-644AR-1 & WW-9222 & CAMS-159989 & Succineidae & 150 & -7.1 & $11.51 \pm 0.03$ & $13.36 \pm 0.08$ & 1.00 \\
\hline AK-645A & WW-7275 & CAMS-143284 & Succineidae & 155 & -6.9 & $11.23 \pm 0.04$ & $13.10 \pm 0.07$ & 1.00 \\
\hline AK-645A & WW-8510 & CAMS-151954 & Succineidae & 155 & -7.2 & $11.32 \pm 0.03$ & $13.17 \pm 0.09$ & 1.00 \\
\hline AK-646A & WW-8511 & CAMS-151956 & Succineidae & 180 & -7.4 & $10.70 \pm 0.03$ & $12.65 \pm 0.06$ & 1.00 \\
\hline AK-646A & WW-7276 & CAMS-143285 & Succineidae & 180 & -6.5 & $10.75 \pm 0.04$ & $12.69 \pm 0.05$ & 1.00 \\
\hline AK-643A & WW-7270 & CAMS-143279 & Succineidae & 180 & -6.7 & $11.01 \pm 0.03$ & $12.87 \pm 0.12$ & 1.00 \\
\hline AK-643A & WW-8508 & CAMS-151952 & Succineidae & 180 & -6.0 & $11.10 \pm 0.03$ & $12.96 \pm 0.11$ & 1.00 \\
\hline AK-643R-1 & WW-9224 & CAMS-159991 & Succineidae & 180 & -6.6 & $11.24 \pm 0.04$ & $13.10 \pm 0.06$ & 1.00 \\
\hline AK-670A & WW-8513 & CAMS-151958 & Succineidae & 200 & -6.9 & $10.30 \pm 0.03$ & $12.06 \pm 0.12$ & 0.94 \\
\hline AK-670A & WW-7284 & CAMS-143293 & Succineidae & 200 & -6.9 & $11.00 \pm 0.04$ & $12.86 \pm 0.13$ & 1.00 \\
\hline AK-681B & WW-7282 & CAMS-143291 & Plant macros & 370 & -25.8 & $15.98 \pm 0.06$ & $19.29 \pm 0.22$ & 1.00 \\
\hline AK-681B & - & Aeon-2427 & $\begin{array}{l}\text { Bulk } \\
\quad \text { organics }\end{array}$ & 370 & - & $13.33 \pm 0.08$ & $16.02 \pm 0.24$ & 1.00 \\
\hline AK-681B & - & Aeon-2433 & Humic acids & 370 & - & $14.99 \pm 0.15$ & $18.23 \pm 0.35$ & 1.00 \\
\hline AK-681B & - & Aeon-2432 & Wood & 370 & - & $15.00 \pm 0.14$ & $18.24 \pm 0.33$ & 1.00 \\
\hline
\end{tabular}


Table 1. (Continued)

\begin{tabular}{|c|c|c|c|c|c|c|c|c|}
\hline Sample ID & Lab \# & AMS \# & $\begin{array}{l}\text { Material } \\
\text { dated }\end{array}$ & $\begin{array}{l}\text { Depth } \\
(\mathrm{cm})^{\mathrm{a}}\end{array}$ & $\begin{array}{c}\delta^{13} \mathrm{C} \\
(\mathrm{VPDB})^{\mathrm{b}}\end{array}$ & $\begin{array}{c}{ }^{14} \mathrm{C} \text { age } \\
\left({ }^{14} \mathrm{C} \text { ka BP }\right)\end{array}$ & $\begin{array}{c}\text { Age } \\
(\text { cal ka BP })^{c}\end{array}$ & $P^{\mathrm{d}}$ \\
\hline \multicolumn{9}{|c|}{ AK-600D, Dalton Highway Milepost $45.8,65.82934^{\circ} \mathrm{N}, 149.48894^{\circ} \mathrm{W}$} \\
\hline YRC-2 & WW-8832 & CAMS-155311 & Succineidae & $38-48$ & -7.7 & $11.27 \pm 0.04$ & $13.13 \pm 0.07$ & 1.00 \\
\hline YRC-6 & WW-8838 & CAMS-155317 & Succineidae & 61 & -7.1 & $11.54 \pm 0.04$ & $13.37 \pm 0.08$ & 1.00 \\
\hline \multicolumn{9}{|c|}{ AK-600E, Dalton Highway Milepost $44.8,65.81827^{\circ} \mathrm{N}, 149.46484^{\circ} \mathrm{W}$} \\
\hline AK-600E-1 & WW-9220 & CAMS-159987 & Succineidae & 20 & -7.5 & $11.36 \pm 0.03$ & $13.20 \pm 0.08$ & 1.00 \\
\hline \multicolumn{9}{|c|}{ AK-DHB, Dalton Highway Milepost $43.5,65.79782^{\circ} \mathrm{N}, 149.44867^{\circ} \mathrm{W}$} \\
\hline DHB-1 & WW-8834 & CAMS-155313 & Succineidae & 15 & -7.1 & $11.88 \pm 0.04$ & $13.67 \pm 0.10$ & 1.00 \\
\hline DHB-2 & WW-8835 & CAMS-155314 & Succineidae & 30 & -7.5 & $11.86 \pm 0.04$ & $13.66 \pm 0.09$ & 1.00 \\
\hline \multicolumn{9}{|c|}{ AK-626W, Dalton Highway Milepost $38.4,65.76788^{\circ} \mathrm{N}, 149.38687^{\circ} \mathrm{W}$} \\
\hline AK-626W-1 & WW-9221 & CAMS-159988 & Succineidae & 70 & -7.4 & $11.01 \pm 0.03$ & $12.87 \pm 0.12$ & 1.00 \\
\hline \multicolumn{9}{|c|}{ AK-626Z, Dalton Highway Milepost $33.5,65.72968^{\circ} \mathrm{N}, 149.29367^{\circ} \mathrm{W}$} \\
\hline AK-626Z-2 & WW-9223 & CAMS-159990 & Succineidae & 80 & -7.8 & $11.81 \pm 0.03$ & $13.65 \pm 0.09$ & 1.00 \\
\hline
\end{tabular}

Note: AMS, accelerator mass spectrometry; VPDB, Vienna Pee Dee belemnite.

${ }^{a}$ Depth from top of exposure.

${ }^{\mathrm{b}}$ Some of the shell aliquots processed at the U.S. Geological Survey (denoted by the prefixes WW- and CAMS-) did not contain enough material for stable isotope analyses and were assigned $\delta^{13} \mathrm{C}$ values of $-8 \%$ (shown in italics). $\delta^{13} \mathrm{C}$ values were not obtained for samples processed at Aeon Laboratories LLC (denoted by the prefix Aeon-).

${ }^{c}$ Calibrated ages were calculated using CALIB v. 7.1html, IntCal13.14 C data set; limit 50.0 calendar ka BP. Calibrated ages are reported as the midpoint of the calibrated range. Uncertainties are reported as the difference between the midpoint and either the upper or lower limit of the calibrated age range, whichever is greater. Multiple ages are reported when the probability of a calibrated age range exceeds 0.05 .

${ }^{\mathrm{d}} P$ is the probability of the calibrated age falling within the reported range as calculated by CALIB.

as $14-16 \%$ and in paleosols, clay content is as high as 9-13\%. In contrast, in unaltered loess, clay contents are less than $10 \%$. Clay enrichment in soils can be attributable either to mechanical infiltration (illuviation) of fine particles from upper soil horizons to lower soil horizons or clay production by chemical weathering of primary silt-sized minerals. The enrichment of fine silt and clay in the same soil and paleosol horizons, as seen in our sections, can also be explained by slow eolian accretion of fine particles during pedogenesis (Muhs et al., 2003b).
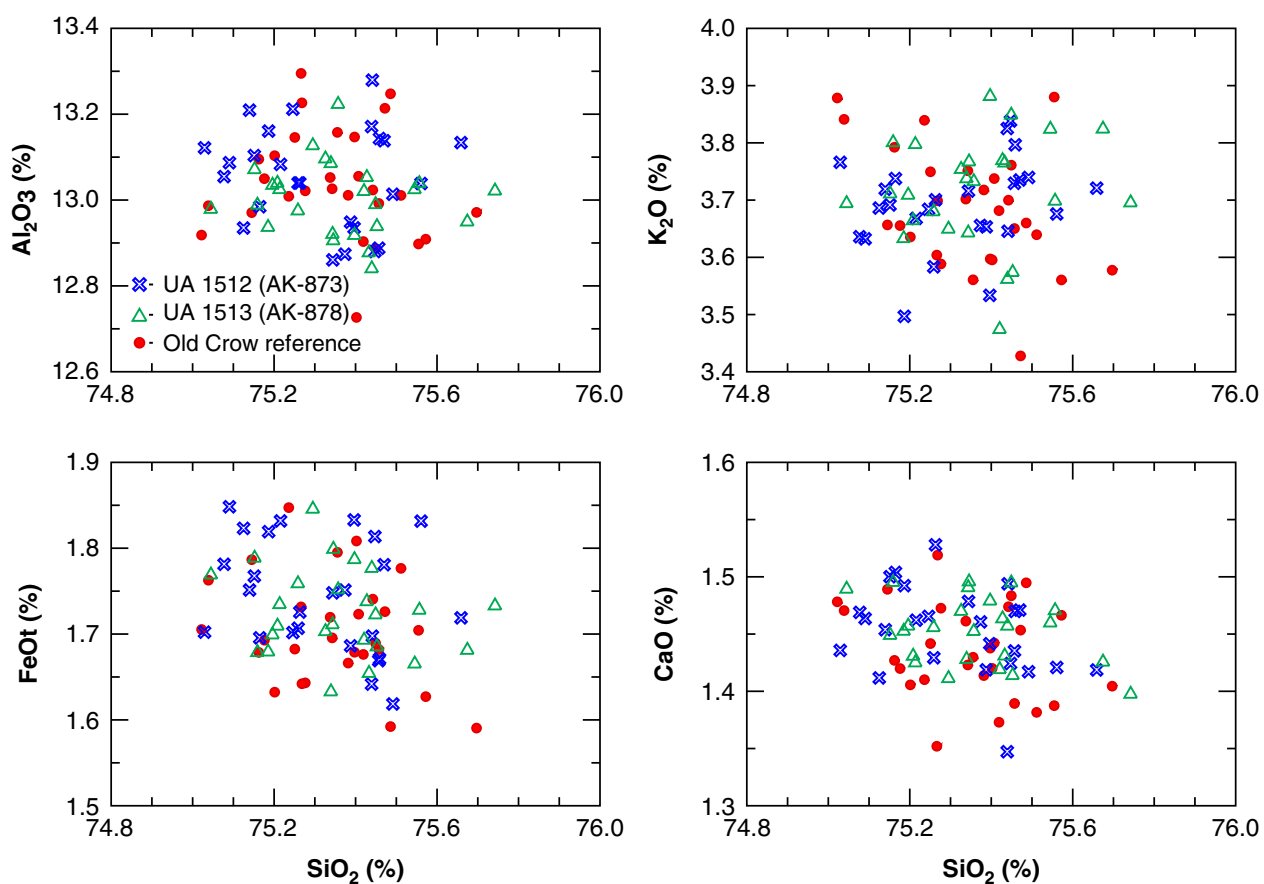

Figure 6. Major element geochemistry of glass shards from ash layer (blue X's) and ash pod (open green triangles) at AK-855 section (Fig. 4d and e). Also shown for reference is major element geochemistry of glass shards from the Old Crow ash (filled red circles) from Togiak Bay, Alaska (TB in Fig. 1b). (For interpretation of the references to color in this figure legend, the reader is referred to the web version of this article.) 
(a)

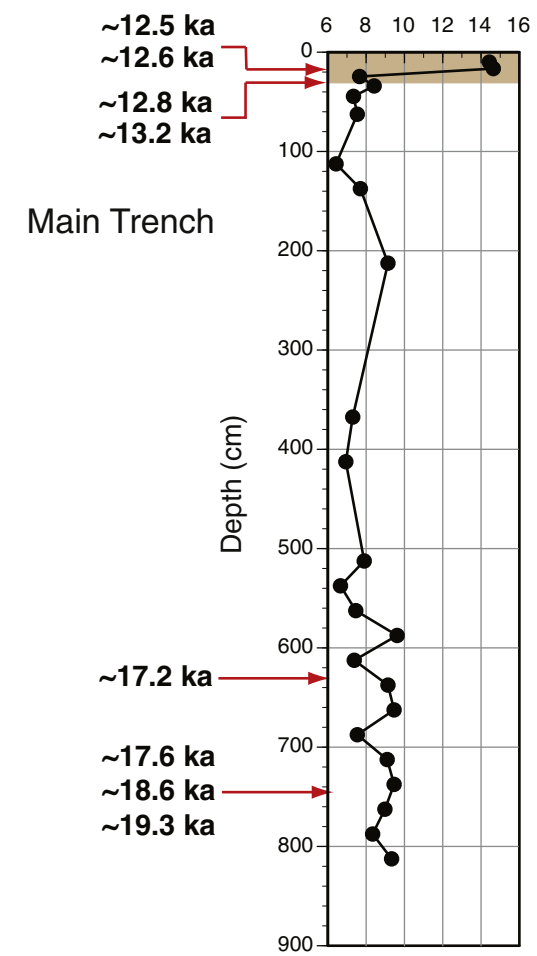

(b)

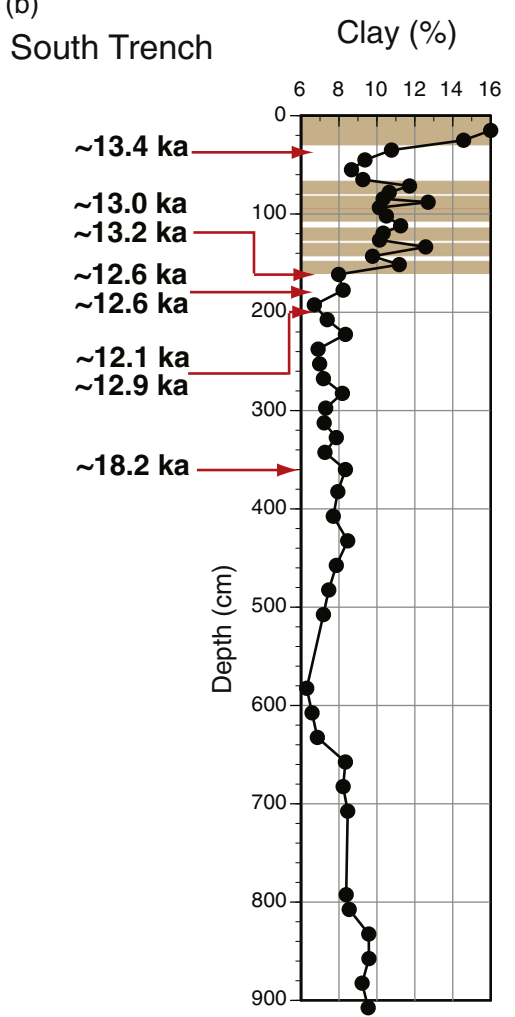

Fine silt (\%)

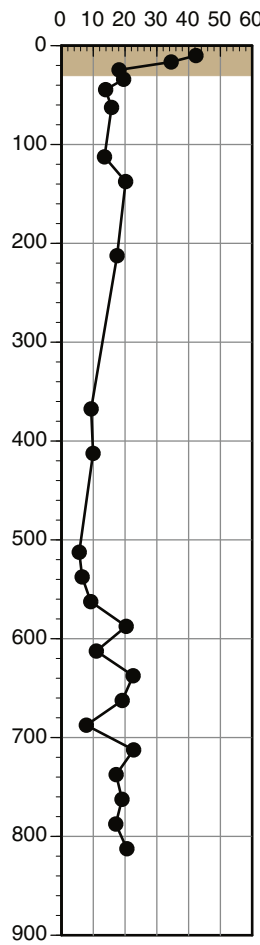

Fine silt (\%)

$0 \quad 102030405060$

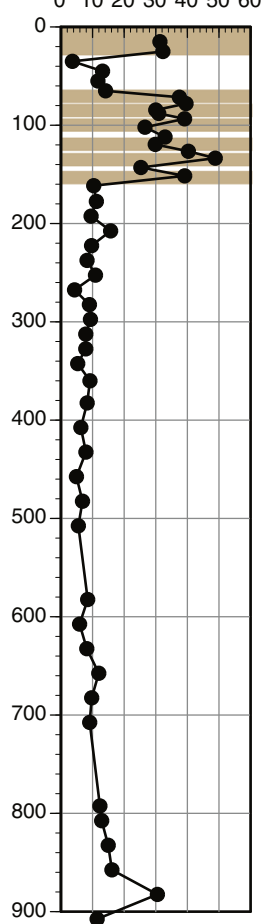

Coarse silt (\%)

30405060708090

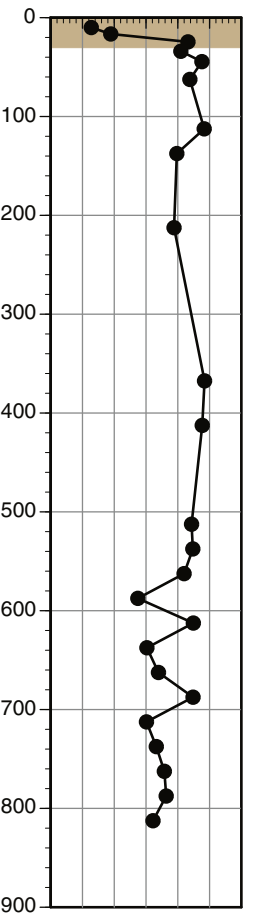

Coarse silt (\%)

30405060708090

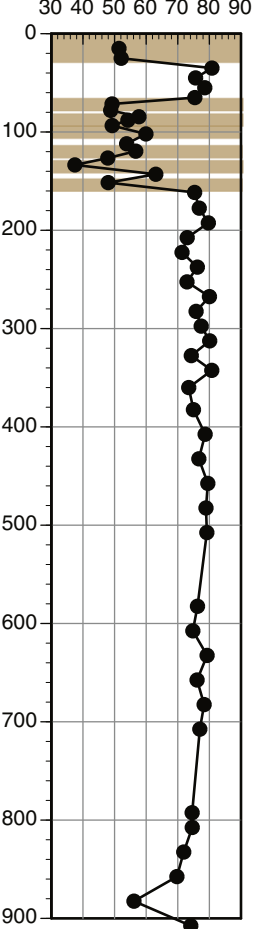

Coarse silt/fine silt

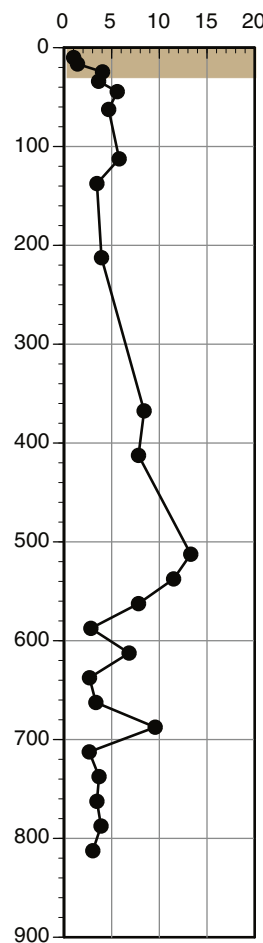

Coarse silt/fine silt

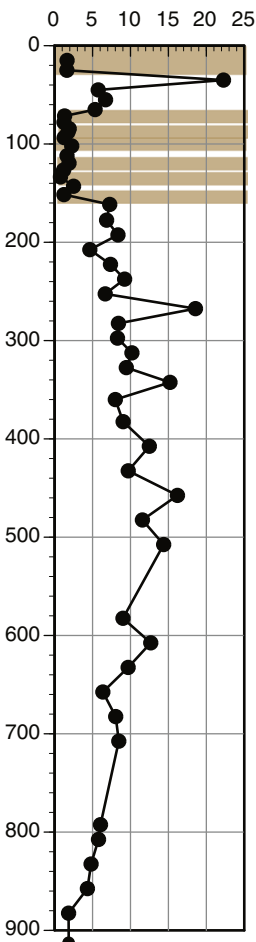

Figure 7. (a) Particle-size distribution of loess and modern soil at the Main Trench section (AK-601A in Figs. 2b and 5a). (b) Particle-size distribution of loess, paleosols, and modern soil at the South Trench section (AK-650A in Figs. 2b and 5a). Numbers in bold in both panels a and $\mathrm{b}$ are radiocarbon ages of land snails (upper parts of sections) and plant remains from peats (lower parts of sections); brown shades are modern soils and paleosols. (For interpretation of the references to color in this figure legend, the reader is referred to the web version of this article.) 

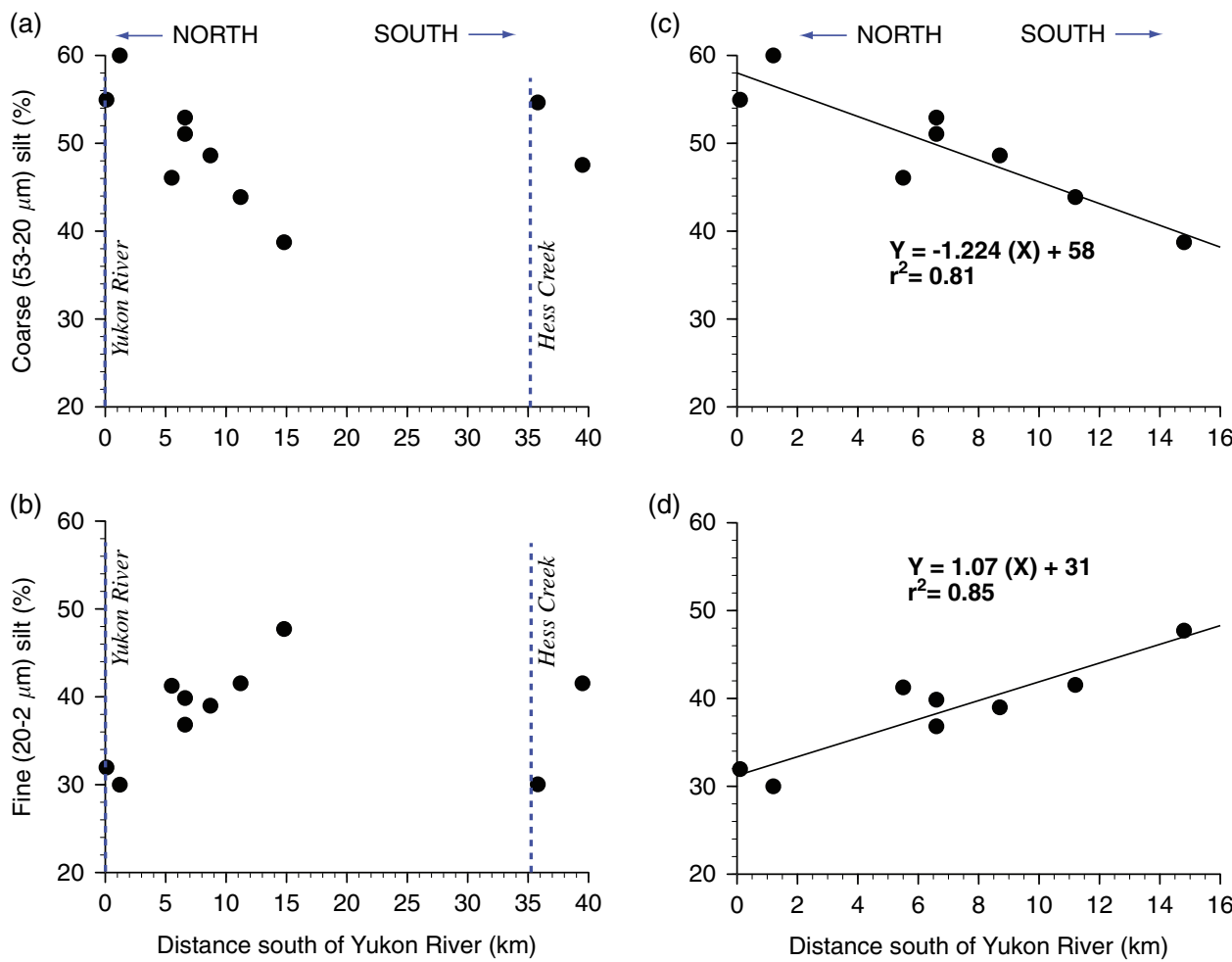

Figure 8. Coarse-silt and fine-silt contents in loess radiocarbon dated to $\sim 13 \mathrm{ka}$ to $\sim 12 \mathrm{ka}$ shown as a function of distance south of the Yukon River: all samples analyzed, with no regression equation computed (localities in Fig. 2b) (a, b); only localities north of Hess Creek, with regression equations and coefficients of determination computed (c, d). Note that sample point for AK-859 ( 1.2 km south of the river) is average of several analyses, excluding one sample at $\sim 30 \mathrm{~cm}$ depth with extraordinarily high coarse-silt content.

From approximately the same depths as our radiocarbondated snails, and below the modern soil zone, we sampled loess in a transect south of the Yukon River (Fig. 2b) for particle-size analyses. With the exception of the two southernmost localities, coarse silt in this 13-12 ka loess decreases, and fine silt increases as a function of distance south of the Yukon River in a linear fashion (Fig. 8), with high coefficients of determination $\left(r^{2}=0.81\right.$ and 0.85 , respectively). Similar distance-from-source trends have been well documented for loess in other localities (e.g., Muhs and Bettis, 2000; Muhs et al., 2013a) and are typically explained as a winnowing of coarse particles away from an alluvial source. It is noteworthy that the two southernmost localities, which do not fit these linear trends, are both south of Hess Creek (Fig. 2b), a major drainage south of the Yukon River. It is possible that Hess Creek served as a secondary source of loess, but this hypothesis requires more testing.

\section{Mineralogy}

The bulk mineralogy of Yukon-Tanana Upland loess was studied at four sections (AK-840, AK-855, the Main Trench [AK-601A], and the South Trench [AK-650A]). Mineralogy is similar in both the section north of the Yukon River (AK-840) and the three sections south of the river. Of the silicate minerals, quartz, plagioclase, K-feldspar, mica, chlorite, and amphibole are found at all depths in unaltered loess (i.e., above or below soils or paleosols). Mica, which appears to be mostly muscovite, is abundant and is easily visible under magnification or even to the naked eye in hand samples. Although the loess contains both K-feldspar and plagioclase, plagioclase is the more abundant of these two minerals based on XRD peak heights. Plagioclase and amphibole are represented in $\mathrm{Na}_{2} \mathrm{O}$ contents in unaltered loess of 1.5-2.7\%; K-feldspar and mica contents are reflected in $\mathrm{K}_{2} \mathrm{O}$ contents of $1.1-2.0 \%$. Chlorite and amphibole are seen in $\mathrm{Fe}_{2} \mathrm{O}_{3}$ concentrations of 3.9-5.0\% (see Supplementary Table 1 for complete geochemical data).

A major difference between loess studied here and loess along the Tanana River near Fairbanks is that Yukon-Tanana Upland loess has a much higher abundance of carbonate minerals, both calcite and dolomite. In both the Main Trench and South Trench, XRD peak-height ratios of calcite to quartz $\left(29.4^{\circ} 2 \theta / 20.9^{\circ} 2 \theta\right)$ and $\mathrm{CaO} / \mathrm{ZrO}_{2}$ vary sympathetically with depth (Fig. 9). From both calcite/quartz and $\mathrm{CaO} /$ $\mathrm{ZrO}_{2}$ values, it is apparent that calcite is largely depleted in the modern soil in the upper parts of both sections and in the paleosols found in the South Trench. Values of $\mathrm{Na}_{2} \mathrm{O} / \mathrm{ZrO}_{2}$ $\mathrm{K}_{2} \mathrm{O} / \mathrm{ZrO}_{2}$ show that plagioclase and mica/K-feldspar, respectively, may have experienced some depletion in the modern soils and paleosols, but not to the degree that carbonate minerals have experienced.

The clay mineralogy of loess along the Yukon-Tanana Upland loess is very similar to the clay mineralogy of loess near Fairbanks, reported by Muhs et al. (2008a). In the Main Trench section, relatively unaltered loess at depths of 
(a)

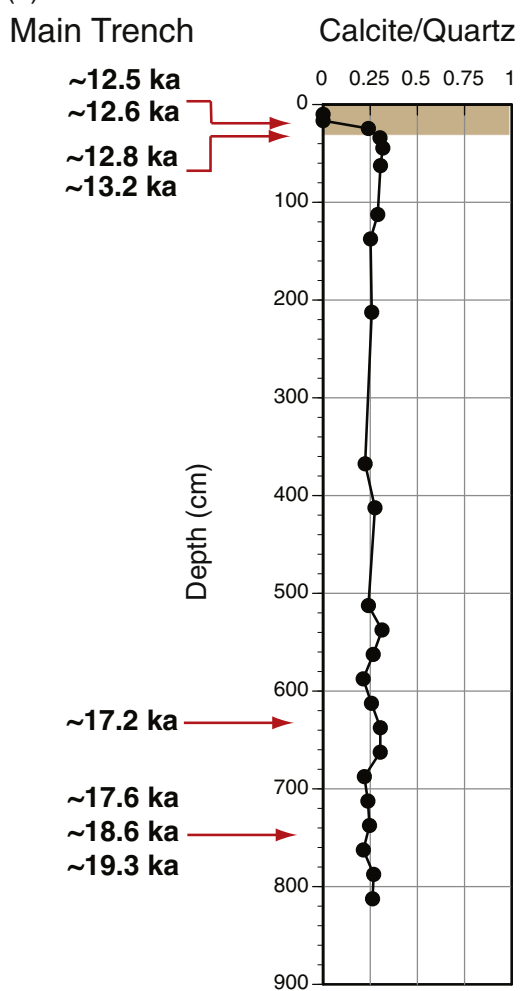

$\mathrm{CaO} / \mathrm{ZrO}_{2}$

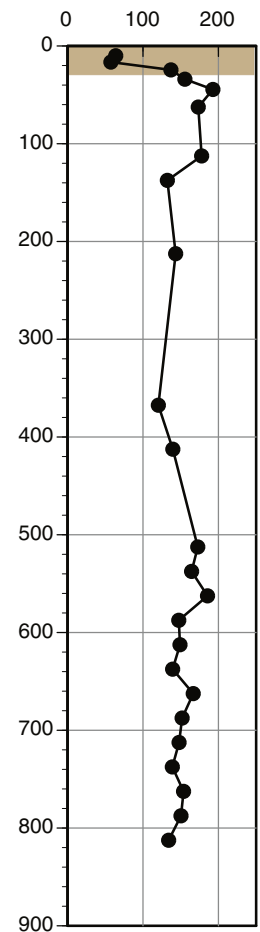

(b)

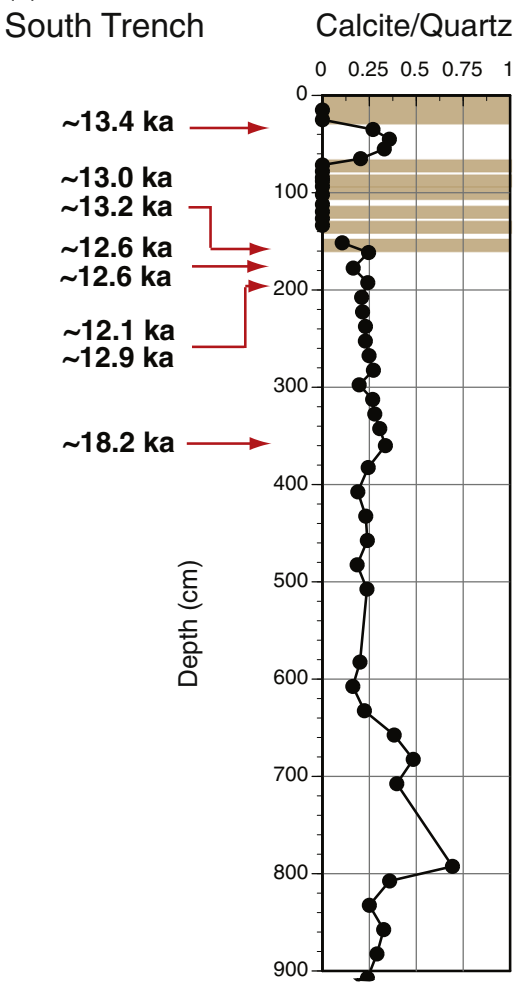

\section{$\mathrm{CaO} / \mathrm{ZrO}_{2}$}

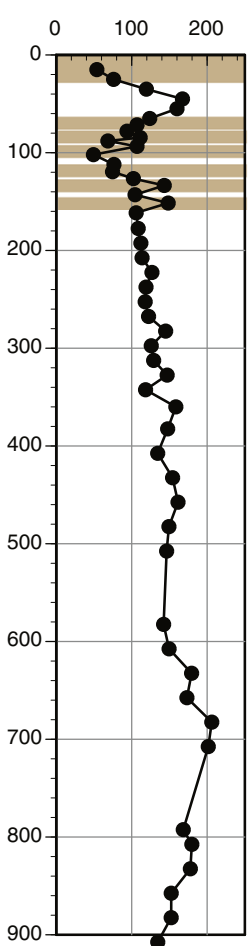

$\mathrm{Na} 2 \mathrm{O} / \mathrm{ZrO}_{2}$

$\begin{array}{llllll}20 & 40 & 60 & 80 & 100\end{array}$
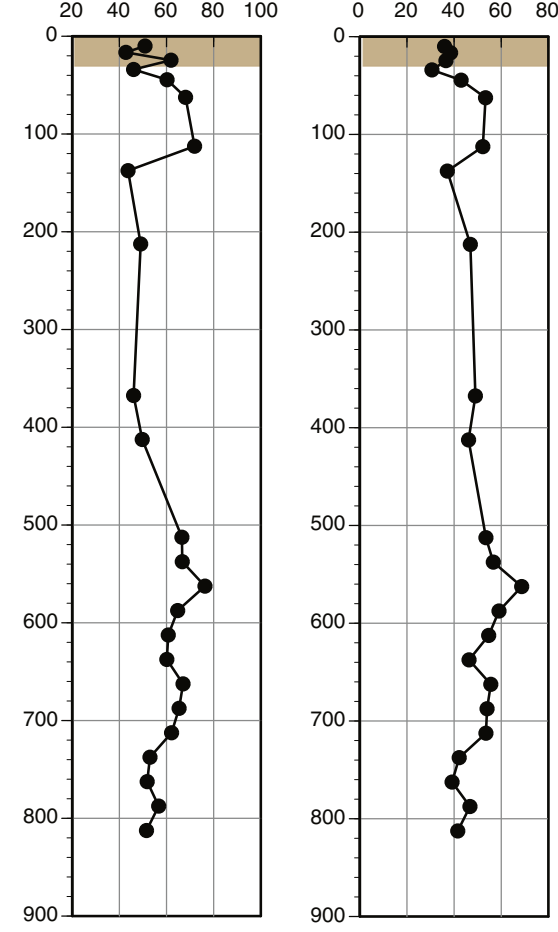

$\mathrm{K}_{2} \mathrm{O} / \mathrm{ZrO}_{2}$

80

900

\section{$\mathrm{Na}_{2} \mathrm{O} / \mathrm{ZrO}_{2}$}

$\begin{array}{llllll}20 & 40 & 60 & 80 & 100\end{array}$

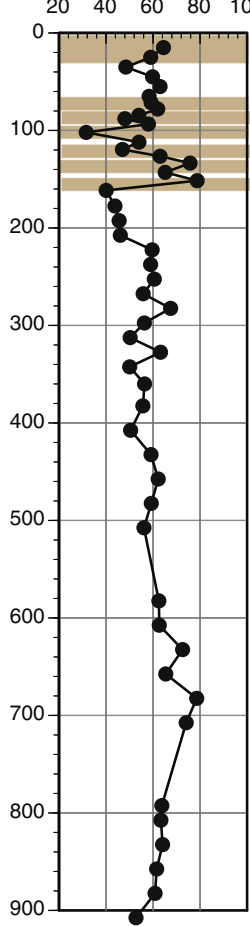

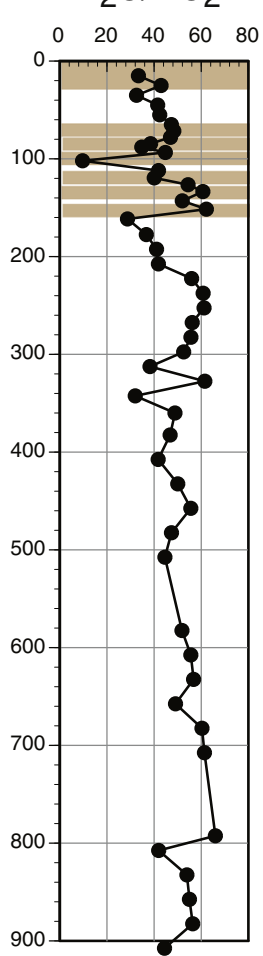

Figure 9. Calcite/quartz values, $\mathrm{CaO} / \mathrm{ZrO}_{2}, \mathrm{Na}_{2} \mathrm{O} / \mathrm{ZrO}_{2}$, and $\mathrm{K}_{2} \mathrm{O} / \mathrm{ZrO}_{2}$ of loess, paleosols, and modern soil at the Main Trench (a) and South Trench (b) sections. Calcite/quartz are relative values only (not weight percent ratios), taken from X-ray diffractometry peak heights of quartz $\left(20.9^{\circ}\right)$ and calcite $\left(29.4^{\circ}\right)$. For both sections, numbers in bold are calibrated radiocarbon ages of land snails (upper parts of sections) and plant remains from peats (lower parts of sections); brown shades are modern soils and paleosols. Note that the modern soil A horizon in the Main Trench is not plotted because it is believed to have been contaminated by carbonate-rich road dust. (For interpretation of the references to color in this figure legend, the reader is referred to the web version of this article.) 


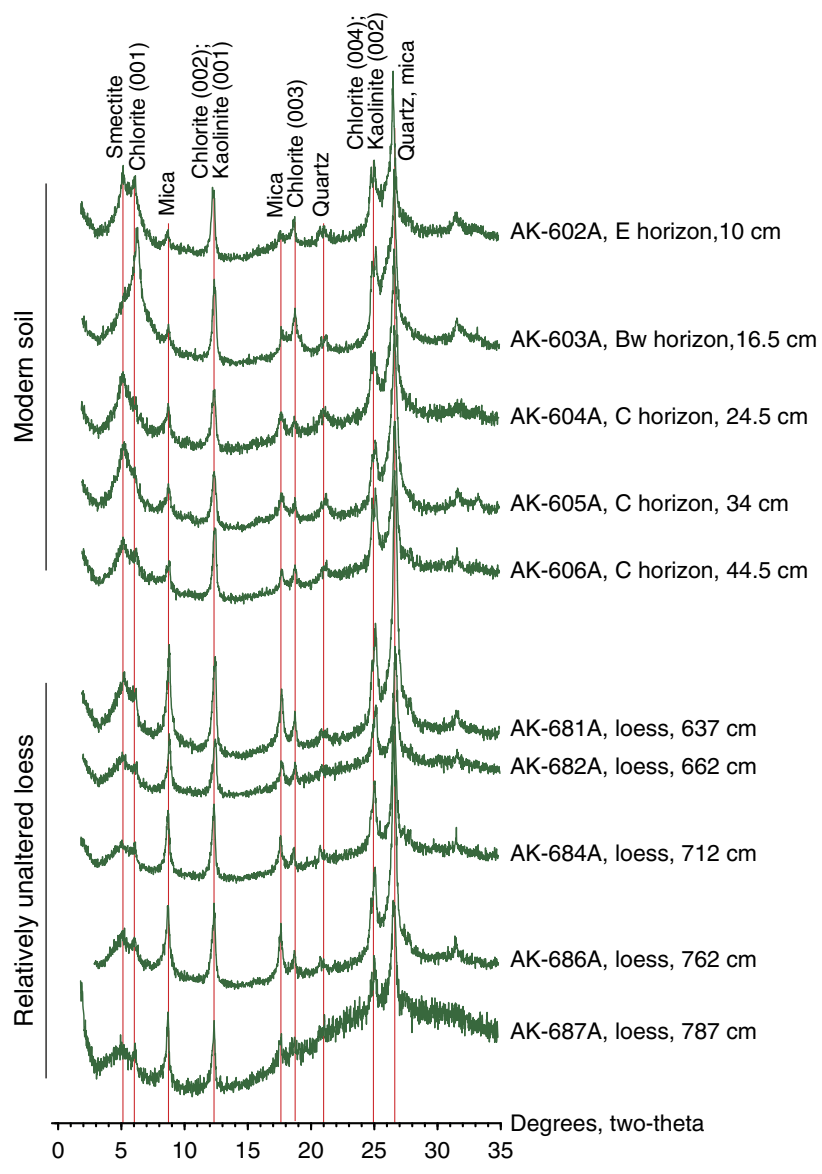

Figure 10. (color online) Selected X-ray diffractograms of glycolated samples of the modern soil and loess from the Main Trench (AK-601A; Fig. 3), showing major clay minerals present.

600-800 cm contains smectite, chlorite, mica, kaolinite, and possibly clay-sized quartz (Fig. 10). For chlorite, the (001) and (003) peaks are less intense than the (002) and (004) peaks on glycolated scans, which could indicate that the chlorite is Fe-rich. It is difficult to be certain about this, however, as kaolinite has (001) and (002) peaks that coincide with the chlorite (002) and (004) peaks. After heating to $550^{\circ}$ $\mathrm{C}$, the (002) and (004) peaks for chlorite are greatly diminished or disappear, meaning that peaks in these positions could be attributable at least partially to kaolinite. Mica in the modern soil shows some depletion compared with unaltered loess, based on peak heights (Fig. 10). This is consistent with the lower $\mathrm{K}_{2} \mathrm{O} / \mathrm{ZrO}_{2}$ values also seen in the modern soil (Fig. 9). In the South Trench, relatively unaltered loess at depths of $\sim 80 \mathrm{~cm}$ to $\sim 140 \mathrm{~cm}$ has a clay mineralogy similar to that of deeper loess in the Main Trench.

\section{Geochemistry and loess provenance}

In order to determine the primary source or sources of loess in the Yukon-Tanana Upland, we calculated key element ratios that can differentiate alluvial silts from different river systems in the region. Given the generally east-west orientation of the major loess bodies in central Alaska, including the YukonTanana Upland and Yukon Flats areas (Fig. 2a), we consider that east-west trending valleys of the Yukon and Tanana Rivers are the most likely sources. Muhs and Budahn (2006) reported that $\mathrm{Cr} / \mathrm{Sc}, \mathrm{Th} / \mathrm{Ta}, \mathrm{As} / \mathrm{Sb}$, and $\mathrm{Zr} / \mathrm{Hf}$, as well as $\mathrm{Eu} / \mathrm{Eu}^{*}$ and $\mathrm{La}_{\mathrm{N}} / \mathrm{Yb}_{\mathrm{N}}$, define distinct compositional fields for silt-sized $(53-2 \mu \mathrm{m})$ particles in these two river systems. Some of these element ratios were also used to distinguish different alluvial sources for loess in the Matanuska Valley and in Wrangell-St. Elias National Park areas (Fig. 1b) of southern Alaska (Muhs et al., 2013b, 2016a).

In addition to the trace elements used by Muhs and Budahn (2006), we investigated the use of $\mathrm{K} / \mathrm{Rb}, \mathrm{K} / \mathrm{Ba}$, and $\mathrm{K} / \mathrm{Cs}$ as provenance indicators. The trace elements $\mathrm{Rb}, \mathrm{Ba}$, and $\mathrm{Cs}$ all substitute for $\mathrm{K}$ in $\mathrm{K}$-bearing minerals such as mica and $\mathrm{K}$-feldspar, both of which are present in Yukon-Tanana Upland loess. Muhs et al. (2008b, 2013b) found that $\mathrm{K} / \mathrm{Rb}$ and $\mathrm{Ba} / \mathrm{Rb}$ values have the ability to discriminate loess bodies derived from different sources in both midcontinental North America and Alaska. In a recent study, Muhs et al. (2016b) used $\mathrm{K} / \mathrm{Rb}$ and $\mathrm{K} / \mathrm{Ba}$ to distinguish competing source sediments for dune sand in southern California. Because $\mathrm{K}, \mathrm{Rb}$, $\mathrm{Ba}$, and $\mathrm{Cs}$ can all be mobile in near-surface environments and in soils, we restrict our use of these elements to deep, unaltered loess, well below modern soils and paleosols, and modern, unweathered alluvium.

In the present study, we determined $\mathrm{K}, \mathrm{Rb}, \mathrm{Ba}$, and $\mathrm{Cs}$ concentrations of the same alluvial samples studied by Muhs and Budahn (2006), from sample localities shown in Figure $2 \mathrm{a}$. Results indicate that in $\mathrm{K} / \mathrm{Rb}$ versus $\mathrm{K} / \mathrm{Ba}$ and $\mathrm{K} / \mathrm{Rb}$ versus K/Cs plots, Yukon River valley silts and Tanana River valley silts define distinctive fields (Fig. 11a and b). Yukon-Tanana Upland loess samples, from sections south of the Yukon River (localities AK-601A, AK-650A, and AK-855 in Fig. 2b), fall largely within the Yukon River valley silts field for $\mathrm{K} / \mathrm{Rb}$ versus $\mathrm{K} / \mathrm{Ba}$ and mostly within that field for $\mathrm{K} / \mathrm{Rb}$ versus $\mathrm{K} / \mathrm{Cs}$ (Fig. 11a and b). Loess from Yukon Flats, north of the Yukon River (locality AK-840 in Fig. 2b), also falls mostly within the Yukon River valley silts field. For Yukon-Tanana Upland loess collected southwest of Circle (Fig. 2a; specific localities are given in Muhs et al., $2003 \mathrm{~b}$ ), we have data on $\mathrm{K} / \mathrm{Rb}$ and $\mathrm{K} / \mathrm{Ba}$ derived from energy-dispersive $\mathrm{X}$-ray fluorescence. All but two of these samples also fall within the Yukon River valley silts field. Because all these elements reflect compositions of K-feldspar and muscovite, they represent a substantial portion of the light, silicate mineral fraction in loess.

$\mathrm{Cr} / \mathrm{Sc}$ and $\mathrm{Th} / \mathrm{Ta}$ values represent trace element compositions of a broad suite of minerals, including micas, amphiboles, and clay minerals, whereas $\mathrm{As} / \mathrm{Sb}$ and $\mathrm{Zr} / \mathrm{Hf}$ represent compositions of specific heavy minerals, magnetite (Onishi and Sandell, 1955) and zircon, respectively. These four element ratios show distinct fields for Yukon River valley silts and Tanana River valley silts (Fig. 12a and b). Both YukonTanana Upland loess (south of the Yukon River) and Yukon Flats loess (north of the Yukon River) plot between the two alluvial fields for $\mathrm{Th} / \mathrm{Ta}$ versus $\mathrm{Cr} / \mathrm{Sc}$ (Fig. 12a). For $\mathrm{Zr} / \mathrm{Hf}$ versus $\mathrm{As} / \mathrm{Sb}$, most loess samples plot within or near the Yukon River valley silts field (Fig. 12b). 

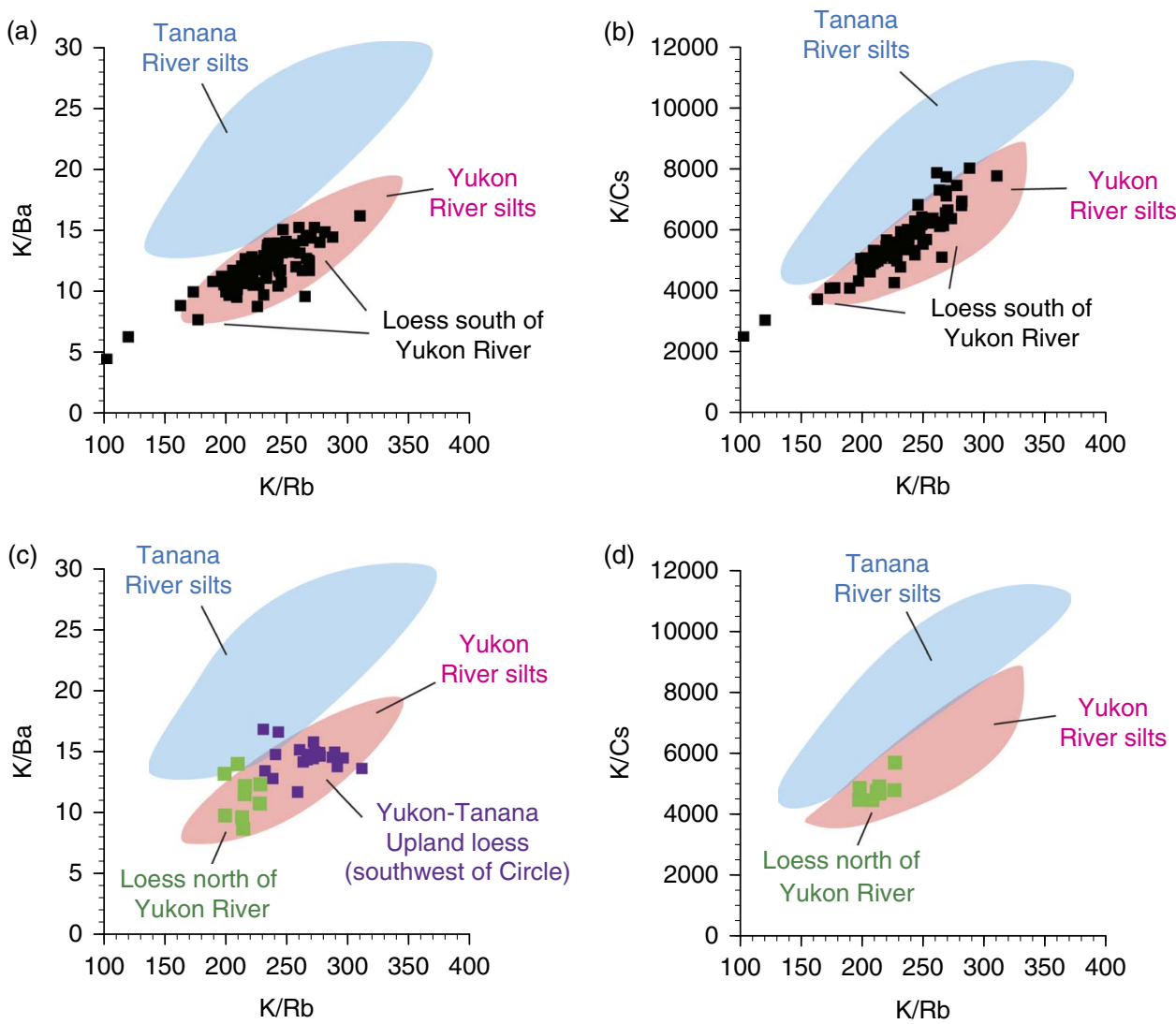

Figure 11. $\mathrm{K} / \mathrm{Rb}$ versus $\mathrm{K} / \mathrm{Ba}$ values in Tanana River and Yukon River silts (blue and pink shaded zones, respectively) (a) and $\mathrm{K} / \mathrm{Rb}$ versus K/Cs values in Tanana River and Yukon River silts (shaded zones) (b) compared with same values in Yukon-Tanana Upland loess samples from south of the Yukon River (localities AK-601A, AK-650A, and AK-855, unaltered loess only), shown as filled black squares. $\mathrm{K} / \mathrm{Rb}$ versus $\mathrm{K} / \mathrm{Ba}$ values in Tanana River and Yukon River silts (shaded zones) (c) and K/Rb versus K/Cs values in Tanana River and Yukon River silts (shaded zones) (d) compared with same values in Yukon Flats loess samples north of the Yukon River (locality AK-840, unaltered loess only), shown as filled green squares. Also shown in panel c are K/Rb and K/Ba values in Yukon-Tanana Upland loess southwest of Circle, Alaska (Fig. 2a); note that these values were obtained by energy-dispersive X-ray fluorescence. (For interpretation of the references to color in this figure legend, the reader is referred to the web version of this article.)

The REEs represent compositions of a broad range of minerals including micas, chlorite, clay minerals, amphiboles, zircon, feldspars (in small amounts), and apatite. $\mathrm{La}_{\mathrm{N}} / \mathrm{Yb}_{\mathrm{N}}$ is a measure of the ratio of light REEs to heavy REEs. The Eu/Eu* value is a measure of the magnitude of the $\mathrm{Eu}$ anomaly (see Taylor and McLennan, 1985). These REE ratios show distinctive compositional fields for Yukon River valley and Tanana River valley silts for $\mathrm{La}_{\mathrm{N}} / \mathrm{Yb}_{\mathrm{N}}$ versus Eu/Eu* (Fig. 12c). Both Yukon-Tanana Upland loess (south of the Yukon River) and Yukon Flats loess (north of the Yukon River) samples fall mostly between the two alluvial compositional fields for $\mathrm{La}_{\mathrm{N}} / \mathrm{Yb}_{\mathrm{N}}$ versus $\mathrm{Eu} / \mathrm{Eu}^{*}$, with a number of samples falling clearly within the Yukon River valley silts field.

\section{DISCUSSION}

\section{Timing of loess deposition along the Yukon River}

As discussed previously, in contrast to the midcontinent of North America, reports of last-glacial-aged loess in Alaska are rare, and the deposits are thin, poorly dated, or simply interpreted to exist from deposits in a favorable stratigraphic position without direct dating. Results presented here document one of the first dated records of loess accumulation during the last glacial period in central Alaska. It is not certain when loess accumulation began during the last glacial period on the western Yukon-Tanana Upland. If the radiocarbon ages of plant remains from peat deposits within the sections exposed at AK-601A and AK-650A are accurate, these data indicate that loess accumulation certainly was in progress by $\sim 19-18 \mathrm{ka}$. By this time, glaciers in both the Brooks Range and Alaska Range had already reached their maximum downvalley positions of the last glacial period and had begun retreating (Fig. 13). However, ice was still much more extensive than present in both mountain ranges until $\sim 11 \mathrm{ka}$. Consistent with the glacial record, loess accumulation continued until at least $\sim 13-12 \mathrm{ka}$ or shortly thereafter, based on radiocarbon ages of snails from the same two sections where the older ages are found, as well as a number of other sections examined both to the north and south of the Yukon River (Fig. 5a). Based on measurements made in the Main Trench, $\sim 7 \mathrm{~m}$ of loess accumulated between $\sim 19 \mathrm{ka}$ and 
(a)

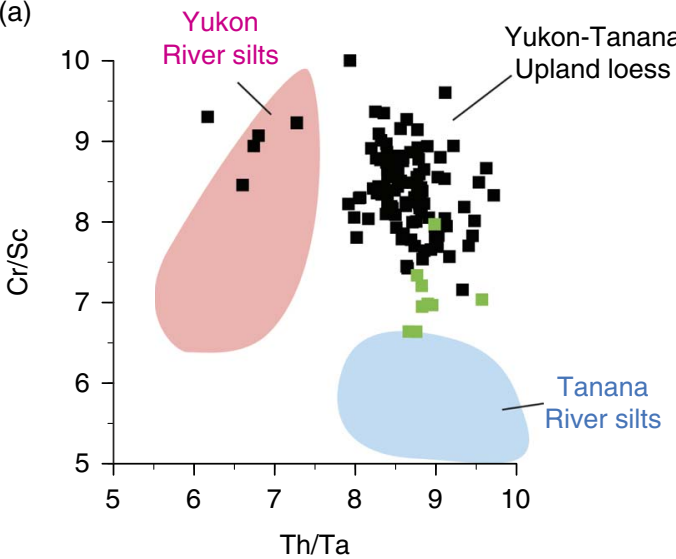

(c)

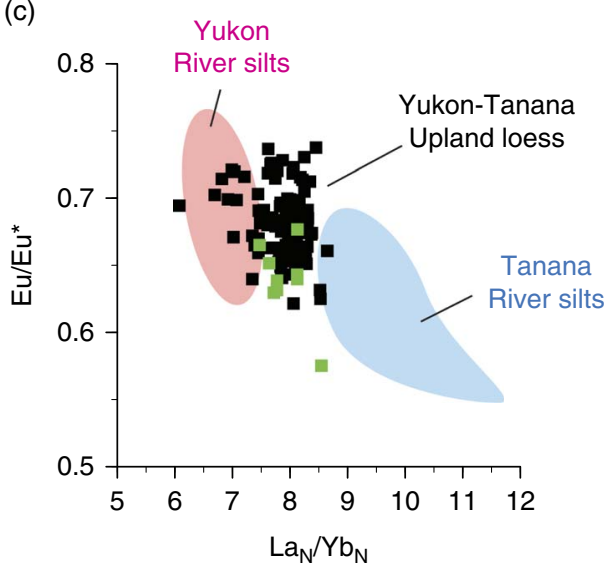

(b)

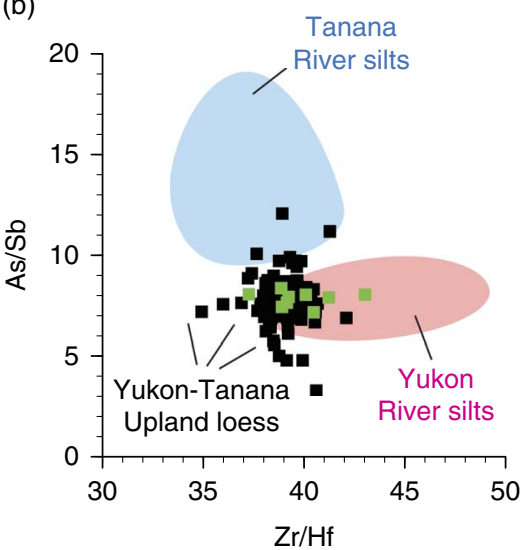

- South of Yukon River - North of Yukon River

Figure 12. Ranges of $\mathrm{Th} / \mathrm{Ta}$ versus $\mathrm{Cr} / \mathrm{Sc}(\mathrm{a}), \mathrm{Zr} / \mathrm{Hf}$ versus $\mathrm{As} / \mathrm{Sb}$ (b), and $\mathrm{La}_{\mathrm{N}} / \mathrm{Yb}_{\mathrm{N}}$ versus Eu/Eu* (c) in Tanana River valley and $\mathrm{Yukon}$ River valley silts (shaded zones). Also shown are values of these ratios in Yukon-Tanana Upland loess (black squares, localities AK-601A, AK-650A, and AK-855) south of the Yukon River and Yukon Flats loess (green squares, locality AK-840) north of the Yukon River. Ranges of values for all river silts are from Muhs and Budahn (2006). (For interpretation of the references to color in this figure legend, the reader is referred to the web version of this article.)

$\sim 13 \mathrm{ka}$ (Fig. 5), demonstrating significant eolian silt deposition during this $\sim 6 \mathrm{ka}$ period. A lack of paleosols in this section indicates that loess sedimentation was more or less continuous over the period between $\sim 19 \mathrm{ka}$ and $\sim 13 \mathrm{ka}$, supported by the fact that calcite and dolomite are present at all depths, indicating that there was no hiatus long enough to bring about complete leaching. At the South Trench, an age of $\sim 19.2 \mathrm{ka}$ also indicates that loess accumulation was in progress during the last glacial period and continued until 13$12 \mathrm{ka}$. The presence of numerous paleosols between $\sim 70 \mathrm{~cm}$ and $\sim 160 \mathrm{~cm}$ in the South Trench is interpreted to indicate episodic slope instability during the latest phases of loess accumulation. The cessation of loess accumulation shortly after $\sim 13-12 \mathrm{ka}$ may be in part attributable to a reduction in glacial silt supplies as ice receded in both the Brooks Range and Alaska Range, mountains that are drained by the Yukon and Tanana Rivers.

At other localities, not enough chronological data are available to ascertain the amount of loess that accumulated solely during the last glacial period. Nevertheless, similar radiocarbon ages near the tops of all sections studied show that loess sedimentation continued until approximately the same time ( $\sim 13 \mathrm{ka}$ to $\sim 12 \mathrm{ka})$ during the very latest part of the last glacial period. Based on the identification of the Old Crow tephra deposits at locality AK-855 (Figs. 4 and 6), loess also accumulated in this area during the penultimate glacial period (MIS 6), based on estimated ages of this widespread stratigraphic marker.

\section{Role of vegetation in loess accumulation}

As mentioned earlier, Muhs et al. (2003b), following Tsoar and Pye (1987), proposed that vegetation plays a key role in loess accumulation, with forest being a more efficient dust trap than grassland or tundra. Understanding Alaska's vegetation history from fossil pollen studies is critical to assessing this hypothesis. Reconstruction of past vegetation from pollen data for interior Alaska indicates that the dominant vegetation at 21-17 ka was graminoid and forb tundra (Anderson and Brubaker, 1994; Edwards et al., 2000; Bigelow et al., 2003). Specifically for the Yukon Flats area, pollen data from a lake record (Sands of Time Lake $\left[66.030^{\circ} \mathrm{N}, 147.548^{\circ} \mathrm{W}\right.$, an informal name) indicate that during full-glacial time ( 21-17 ka), vegetation was characterized by abundant 
(a)

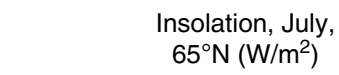

(b)

Brooks Range glacial history (c)

Alaska Range glacial history (d)

Interior Alaska vegetation (e)

Yukon-Tanana Upland loess history

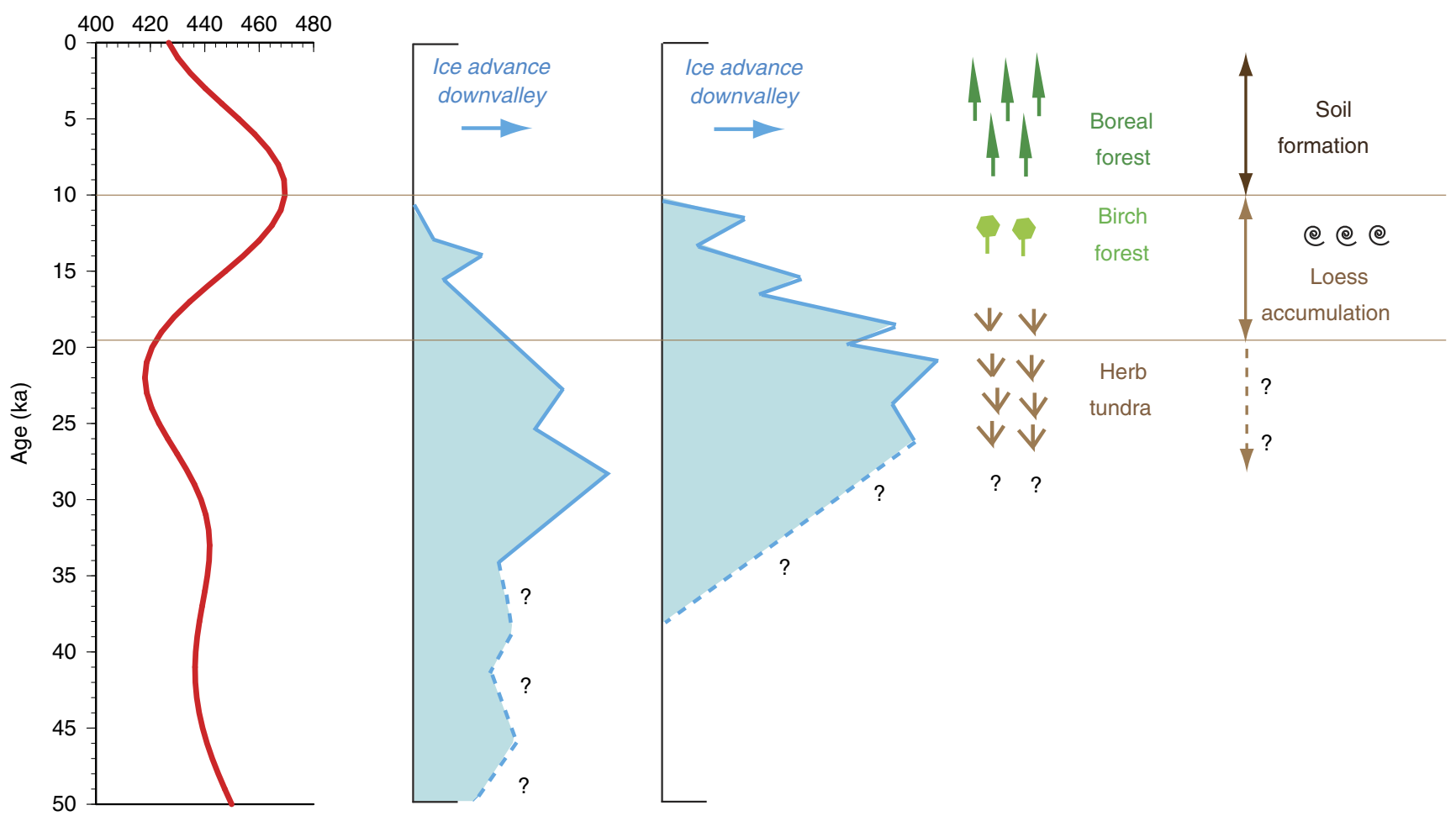

Figure 13. (color online) Comparison of geologic records in Alaska over the past $50 \mathrm{ka}$. (a) Insolation at the top of the atmosphere in July at $65^{\circ} \mathrm{N}$ (from Berger and Loutre, 1991). Time-distance diagrams of Brooks Range (b) and Alaska Range (c) glaciers, constrained by calibrated radiocarbon and cosmogenic ages, dashed where uncertain (redrawn from Briner and Kaufman, 2008). (d) Vegetation history of interior Alaska, generalized from Anderson and Brubaker (1994), Edwards and Barker (1994), Edwards et al. (2000, 2016), and Bigelow et al. (2003). (e) History of loess accumulation and soil formation in the Yukon-Tanana Upland (this study).

Poaceae (grasses), Cyperaceae (sedges), Chenopodiaceae (chenopods), and other herbaceous taxa (Edwards and Barker, 1994). Furthermore, Edwards and Barker (1994) note that at this time, pollen accumulation rates were very low, which they interpret to mean a landscape that was very sparsely vegetated. By $\sim 13 \mathrm{ka}$, however, herb tundra had diminished and birch (Betula) had arrived in the area, with poplar (Populus) becoming abundant by $\sim 12 \mathrm{ka}$ to $\sim 10 \mathrm{ka}$, and finally spruce (Picea) and alder (Alnus) arriving at $\sim 10 \mathrm{ka}$ and $\sim 9 \mathrm{ka}$, respectively (Edwards and Barker, 1994; Edwards et al., 2016). It is important to note here that an apparent rise in Betula pollen earlier in the record (starting at $\sim 20 \mathrm{ka}$, with up to $50 \%$ Betula pollen between $\sim 18 \mathrm{ka}$ and $\sim 14 \mathrm{ka}$ ) at Sands of Time Lake, previously reported by Lamb and Edwards (1988) and Edwards and Barker (1994), is now interpreted to be attributable to reworking of older grains (Edwards et al., 2016).

If the radiocarbon ages from deep within the Main Trench $(\sim 18.6 \mathrm{ka}$ and $\sim 17.2 \mathrm{ka})$ are accurate, these data imply that loess accumulation was in progress during the last glacial period, likely under an herb tundra vegetation until $\sim 13 \mathrm{ka}$, when birch arrived in the Yukon Flats area. The radiocarbon ages of $\sim 13 \mathrm{ka}$ to $\sim 12 \mathrm{ka}$ for land snails at shallow depths in our sections indicate that loess accumulation was nearing its end at about the time of birch arrival in the Yukon Flats area.
The accumulation of loess under an herb tundra vegetation (with its low roughness height) and its termination with the arrival of birch (with a higher roughness height) is completely contrary to the hypothesis proposed by Muhs et al. (2003b). Thus, although it is based on sound aerodynamic considerations presented by Tsoar and Pye (1987), the hypothesis of vegetation control on loess accumulation proposed by Muhs et al. (2003b) may need revision. On the other hand, it is possible that the arrival of birch in the region at $\sim 13 \mathrm{ka}$ may have stabilized river floodplains, such that sediment availability in the source valleys was diminished, which would explain the termination of loess accumulation.

The presence of snails in significant concentrations in only the upper part of the Yukon-Tanana Upland loess differs from loess of midcontinental North America, where snails are found throughout the depths of last-glacial-aged Peoria Silt (see examples in Pigati et al., 2013, 2015). Previously, we noted that the snails in the Yukon-Tanana Upland and Yukon Flats loess could be Succinea strigata, as identified by Williams (1962) in loess elsewhere in the area. Based on localities given in Pilsbry (1948), this species has a modern distribution that spans a range of high-latitude climate and vegetation zones, including coastal forest in southeastern Alaska, boreal forest in interior Alaska and Yukon Territory, 
cottonsedge tundra and watersedge tundra in western Alaska, and Aleutian heath in the Aleutian Islands. Over this suite of biomes, mean July temperatures range from $\sim 8^{\circ} \mathrm{C}$ to $\sim 16^{\circ} \mathrm{C}$. Thus, it does not seem likely that a change in summer temperatures was a likely cause for the arrival of $S$. strigata in the Yukon-Tanana Upland. It is possible that at the close of the last glacial period, when herb tundra gave way to birch forest and boreal forest (Edwards and Barker, 1994), increased moisture played a role in providing a more favorable environment for the presence of $S$. strigata.

Although most fossil snails examined were found close to the modern land surface, there is a small but measurable amount of loess above most of them and below the modern soil profile. The modern soil profiles appear to have developed within this thin loess, which was apparently deposited after 13-12 ka. Modern soils at all localities examined have $\mathrm{O} / \mathrm{E} / \mathrm{Bw} / \mathrm{C}$ or $\mathrm{A} / \mathrm{E} / \mathrm{Bw} / \mathrm{C}$ profiles and are classified as Typic Cryochrepts. The presence of an $\mathrm{E}$ horizon in these soils is significant, as it indicates that the soils likely developed primarily under boreal forest. Holocene soils that develop under either coastal forest or boreal forest in Alaska have $\mathrm{E}$ horizons, whereas those developed under shrub tundra or herb tundra typically do not (see examples in Muhs et al., 2000; an exception is the development of $\mathrm{E}$ horizons under acidic tundra in the Talkeetna Mountains of southern Alaska). Thus, given the time of arrival of Picea and other boreal forest taxa in the area (Anderson and Brubaker, 1994; Edwards et al., 2016), the modern soils likely developed their present morphologies no earlier than $\sim 10 \mathrm{ka}$.

\section{Differences in loess stratigraphic records of central Alaska}

A major stratigraphic difference between the loess sections observed along the Yukon River and those in the Fairbanks area is the lack of evidence for significant Holocene loess in the Yukon-Tanana Upland. In the Fairbanks area, radiocarbon dating has established that 1-4m of loess accumulated at a number of sites in the area during the Holocene (Péwé, 1975b; Hamilton et al., 1988; Begét, 1990; Muhs et al., 2003b). Because only very thin loess is found above the snails dated $\sim 13 \mathrm{ka}$ to $\sim 12 \mathrm{ka}$ in the Yukon-Tanana Upland, it could be argued that no Holocene loess was deposited at all in the area (although see locality Q of Froese et al., 2005). It is possible that this difference is related to glacial supplies. Although they were much larger and extended farther downvalley during the last glacial period, there are still extensive glaciers in the Alaska Range (Fig. 1b). Many of the rivers and streams that drain the north side of this mountain range are tributaries to the Tanana River (Fig. 2a), whose valley is the primary source of loess in the Fairbanks area (Muhs and Budahn, 2006). Thus, glaciogenic silt is still available from the Tanana River valley and its tributaries that drain the Alaska Range. In contrast, although glaciers were extensive on the south side of the Brooks Range during the last glacial period (Hamilton, 1982; Kaufman et al., 2004; Briner and Kaufman, 2008), those that still exist in these mountains are much smaller and mostly limited to the northeastern part of the range. Thus, although glaciogenic silt supplies are still delivered in abundance to the Tanana River, such supplies are far more limited in the Yukon River drainage basin.

\section{Sources of loess in the western Yukon-Tanana Upland}

Given the proximity of Yukon-Tanana Upland loess to the Yukon River, it might seem obvious that the valley of this river must be the major source of the loess. Nevertheless, previous studies have shown that elsewhere in Alaska, loess sources are complex and not always so easily identified. For example, in the Fairbanks area, although the nearby Tanana River valley was a major source of Pleistocene loess, the Yukon River valley was also a contributor and even the Nenana River valley made contributions (Muhs and Budahn, 2006). In southern Alaska, it would be easy to assume that both the Matanuska River valley and Knik River valley are sources for loess in the Matanuska Valley, as both river systems are upwind of the major loess body in this valley. Yet, geochemical data show that the Knik River valley actually makes only minor contributions, if any, to the loess (Muhs et al., 2016a).

Recognizing that a complex origin is possible, particle-size data do support an interpretation that Yukon River valley sediments were important to the accumulation of loess in the Yukon-Tanana Upland. Ratios of coarse silt to fine silt have been commonly employed as a measure of wind strength, with applications to loess history in Europe, Asia, and North America (e.g., Rousseau et al., 2007; Machalett et al., 2008; Antoine et al., 2009; Muhs et al., 2013b). Such measures are referred to as "grain size indexes" (GSI) or "U-ratios," and although the specific size cutoffs vary somewhat from study to study, all of them are basically measures of the coarse-silt fraction to the fine-silt fraction. In these studies, such ratios are almost always less than 5 and usually less than 3 . Below the modern soil and shallow paleosols in both the Main Trench and South Trench, coarse-silt/fine-silt values (Fig. 7) are much higher than those reported in last-glacial loess sequences in Germany, Serbia, and Kazakhstan (Rousseau et al., 2007; Machalett et al., 2008; Antoine et al., 2009). The Alaskan coarse-silt/fine-silt values are as high as 13 (Main Trench) and 22 (South Trench) and in general are closer to those found in loess at Loveland, Iowa, where a thick $(\sim 40 \mathrm{~m})$, last-glacial loess accumulation is situated within a kilometer of its Missouri River valley source (Muhs and Bettis, 2000; Muhs et al., 2013a). From this, we infer that the primary loess source for the Yukon-Tanana Upland was likely nearby and/or that winds were strong in this region during the time of eolian silt transport. Further, particle-size data acquired along a transect to the south of the Yukon River show a distinct decrease in coarse silt and increase in fine silt in a southward direction (Fig. 8), at least until one reaches Hess Creek, a possible local source of loess (Fig. 2b). This again implies a source to the north, the most obvious of which is the Yukon River valley. 
Mineralogy also provides an assessment of possible sources of Yukon-Tanana Upland loess. Based on bulk silicate mineralogy (quartz, plagioclase, K-feldspar, mica, amphibole, and chlorite), either the Yukon River valley, the Tanana River valley, or both valleys could be sources of loess. Similarly, clay mineralogy of alluvium from the two river valleys does not differ significantly (see fig. 9 of Muhs et al., 2008a) and the clay mineralogy of Yukon-Tanana Upland loess (Fig. 10) would permit an interpretation of contributions from either river valley. Carbonate minerals, both calcite and dolomite, are present in loess on the Yukon-Tanana Upland, unlike most Fairbanks area loess (Fig. 9). Muhs et al. (2008a) interpreted the lack of carbonates in Fairbanks area loess to be attributable to syndepositional leaching. Although modern alluvial silts in both the Tanana River valley and Yukon River valley both contain calcite and dolomite, overall, the abundance of carbonate minerals is higher in modern Yukon River valley sediments $(\sim 10 \%)$ compared with Tanana River valley sediments $(\sim 3 \%)$, based on analyses by Eberl (2004). Values of $\mathrm{CaO}$ content and $\mathrm{CaO} / \mathrm{ZrO}_{2}$ in alluvial silts from these river valleys reported by Muhs and Budahn (2006) and Muhs et al. (2008a) are consistent with Eberl's (2004) findings. Concentrations of $\mathrm{CaO}$ in Tanana River valley silts range from 3.3 to 6.0, whereas in the Yukon River valley, alluvial silts have $\mathrm{CaO}$ concentrations that range from 6.4 to 10.1 (see Supplementary Table 2). Values of $\mathrm{CaO} / \mathrm{ZrO}_{2}$ in Tanana River valley silts range from 47 to 127 (mean of 93), whereas these values in Yukon River valley silts range from 91 to 354 (mean of 185). In YukonTanana Upland loess, below the modern soil, $\mathrm{CaO} / \mathrm{ZrO}_{2}$ values in the Main Trench range from 132 to 192 (Fig. 9). In the South Trench, $\mathrm{CaO} / \mathrm{ZrO}_{2}$ values (excluding the modern soil and paleosols) range from 106 to 206 and below a depth of $\sim 2 \mathrm{~m}$, values are no lower than 114 . These observations imply that even if some syndepositional leaching had occurred, the higher carbonate contents and higher $\mathrm{CaO} / \mathrm{ZrO}_{2}$ values in Yukon-Tanana Upland loess require a significant Yukon River valley contribution.

Finally, geochemical methods also provide a means of distinguishing loess sources. Values of $\mathrm{K} / \mathrm{Rb}, \mathrm{K} / \mathrm{Ba}$, and $\mathrm{K} / \mathrm{Cs}$, representing K-feldspar and mica, define nonoverlapping geochemical fields for Yukon River valley silts and Tanana River valley silts (Fig. 11). Loess from the YukonTanana Upland falls almost wholly within the Yukon River valley fields for these ratios, indicating that this fluvial system is a significant loess source. Geochemical indicators of the heavy mineral fraction, $\mathrm{Zr} / \mathrm{Hf}$ (zircon) and $\mathrm{As} / \mathrm{Sb}$ (magnetite), also support a Yukon River valley source, although there is more variability. Other geochemical indicators, however, such as $\mathrm{Th} / \mathrm{Ta}$ and $\mathrm{Cr} / \mathrm{Sc}$, permit an interpretation of some Tanana River valley contributions as well as Yukon River valley contributions (Fig. 12). Furthermore, although $\mathrm{La}_{\mathrm{N}} /$ $\mathrm{Yb}_{\mathrm{N}}$ versus $\mathrm{Eu} / \mathrm{Eu} *$ values show clearly defined fields for the two river sources, Yukon-Tanana Upland loesses fall between the two geochemical fields for the river valleys. We conclude from all the geochemical data that although the Yukon River valley is likely the most important source for
Yukon-Tanana Upland loess, it cannot be the only source. Geochemical data permit an interpretation of at least some eolian input of Tanana River valley-derived sediments to the Yukon-Tanana Upland. Particle transport from the Tanana River valley to the Yukon-Tanana Upland would occur over a significantly greater distance than transport from the Yukon River valley (Fig. 2a). Because of this greater transport distance, we suspect that the component of Yukon-Tanana Upland loess derived from the Tanana River is largely in the fine-silt $(20-2 \mu \mathrm{m})$ and clay $(<2 \mu \mathrm{m})$ fractions. This hypothesis could be tested easily with geochemical analyses of different particle-size classes.

\section{Paleoclimatic considerations}

Identification of the Yukon River valley as the primary source of last-glacial loess to the Yukon-Tanana Upland supports the inference of northeasterly paleowinds in interior Alaska by Hopkins (1982) and Lea and Waythomas (1990), based on eolian sand records. If, however, as the geochemical data indicate, the Tanana River valley was an additional contributing source to loess on the Yukon-Tanana Upland, then it is necessary to consider the paleoclimatic conditions that would bring about dual loess sources. Because the western Yukon-Tanana Upland is situated between the two river valleys, the implications of our findings are that winds that transported silt came at times from the north and at other times came from the south.

Muhs and Budahn (2006), in interpreting multiple sources of loess in the Fairbanks area, proposed that katabatic winds in Alaska's mountain ranges could have brought about opposing paleowinds in the past. Katabatic winds are strong, gravity-driven, downslope winds caused by nocturnal surface cooling (Barry, 1992). They are best known from the large ice sheets of Greenland and Antarctica but can occur in much more local environments as well (see examples in Barry, 1992). Schaetzl and Attig (2013) provide evidence that lastglacial-aged loess accumulation in some parts of the North American midcontinent was influenced by katabatic winds coming off the Laurentide Ice Sheet. Thorson and Bender (1985), Guthrie (1990), Muhs et al. (2003b), and DiPietro et al. (2017) have all inferred that such winds could have played a role in silt particle entrainment during the last glacial period in Alaska. In both the Brooks Range and the Alaska Range, glaciers advanced to downvalley positions, compared with where they are now, during the last glacial period (Figs. 2a and 13). During the last glacial period, because glaciers flowed both south out of the southern Brooks Range and north out of the northern Alaska Range, the potential existed for the development of katabatic winds with opposing directions. It is proposed here that these opposing katabatic winds played a role in the generation of loess in the YukonTanana Upland area.

Seasonality could also have played a role in the timing of eolian silt entrainment during the last glacial period. A recent global climate simulation by Alder and Hostetler (2015) presents surface paleowinds at $3 \mathrm{ka}$ intervals over the past 
21 ka. In winter (December, January, and February), surface winds in interior Alaska at $21 \mathrm{ka}$ and $18 \mathrm{ka}$ are simulated to be much stronger than present and dominantly from the east or northeast. In summer (June, July, and August), winds at $21 \mathrm{ka}$ and $18 \mathrm{ka}$ are also simulated to be stronger than present (though weaker than during winter), but from the south. If this reconstruction is correct, Yukon-Tanana Upland loess that was derived from the Yukon River valley could have been entrained largely during the colder months of the year, whereas Yukon-Tanana Upland loess that was derived from the Tanana River valley could have been entrained during the warmer months of the year.

\section{CONCLUSIONS}

Loess in Alaska has traditionally been associated with glacial periods, but loess deposits confidently dated to the last glacial period are scarce. We report here a rare occurrence of loess dating to this period on the lower slopes of the western Yukon-Tanana Upland of central Alaska. In the thickest sections, radiocarbon ages of plant materials from buried peats (deep in the sections) and land snails (near the surface) indicate that loess deposition was in progress by $\sim 19 \mathrm{ka}$ and terminated sometime shortly after $\sim 13 \mathrm{ka}$ to $\sim 12 \mathrm{ka}$. Loess near the Yukon River is as much as $\sim 10 \mathrm{~m}$ thick and thins, in an irregular fashion, to the south. Within a few kilometers of the river, the loess has abundant coarse particles, with high coarse-silt/fine-silt values, implying strong winds and/or a nearby source. However, coarse-silt contents decrease to the south, with a concomitant increase in fine-silt contents. All these observations imply that the Yukon River valley was a major loess source during the last glacial period.

The presence of abundant carbonate minerals (calcite and dolomite) in Yukon-Tanana Upland loess contrasts with loess of the Fairbanks area, and also implicates the Yukon River valley as a source, because sediments in this river system are high in carbonate minerals. Nevertheless, geochemical data indicate that Yukon River valley silts cannot be the only source, and Tanana River valley silts appear to be a contributing source. If so, this implies that southerly winds must have been present during the last glacial period, because the Tanana River is situated to the south of the western Yukon-Tanana Upland. Reconciliation of both a dominantly northerly loess source (Yukon River valley) and a secondary southerly loess source (Tanana River valley) is possible with consideration of the role of opposing katabatic winds. Because glaciers expanded in both the southern Brooks Range (to the north) and the northern Alaska Range (to the south) during the last glacial period, the Yukon-Tanana Upland, between these two mountain ranges, was in a position to receive sediment from both directions because of strong katabatic winds over these ice bodies. An alternative interpretation comes from a recent climate model for the last glacial period in Alaska. This model simulates southerly winds during last-glacial summers in Alaska and northerly winds during last-glacial winters, suggesting seasonality could play a role in changing loess sources. With either interpretation, the observations made here indicate that loess accumulation in central Alaska during the last glacial period likely had a complex origin.

\section{ACKNOWLEDGMENTS}

The Climate and Land Use Change Research and Development Program of the U.S. Geological Survey (USGS) supported this study. We thank the Alaska Department of Transportation and Public Facilities (Division of Maintenance and Operations) for allowing us to study the sections along the Dalton Highway when they were newly exposed in 2006. Jossh Beann (USGS, retired), Zachary Muhs Rowland (USGS volunteer), and Peter Rowland (USGS volunteer) assisted with fieldwork, which we appreciate. We extend sincere thanks to our good friend, Jack McGeehin (USGS, retired), for generating the radiocarbon ages. We appreciate helpful discussions with Duane Froese (University of Alberta) about tephra geochemistry and with Steve Hostetler (USGS) about paleoclimatic interpretations. Dave Grimley (Illinois State Geological Survey), Pierre Antoine (CNRS, Laboratoire de Géographie Physique), Randy Schaetzl (Michigan State University), Adam Hudson (USGS), and Janet Slate (USGS) offered helpful comments on an earlier version of this paper, for which we extend our thanks. Any use of trade, product, or firm names is for descriptive purposes only and does not imply endorsement by the U.S. government.

\section{SUPPLEMENTARY MATERIAL}

To view supplementary material for this article, please visit https://doi.org/10.1017/qua.2018.11

\section{REFERENCES}

Ager, T.A., 2003. Late Quaternary vegetation and climate history of the central Bering land bridge from St. Michael Island, western Alaska. Quaternary Research 60, 19-32.

Ager, T.A., Brubaker, L.B., 1985. Quaternary palynology and vegetational history of Alaska. In: Bryant, V.M., Jr., Holloway, R.G. (Eds.), Pollen Records of Late-Quaternary North American Sediments. American Association of Stratigraphic Palynologists Foundation, Dallas, TX, pp. 353-383.

Alder, J.R., Hostetler, S.W., 2015. Global climate simulations at 3000year intervals for the last 21000 years with the GENMOM coupled atmosphere-ocean model. Climate of the Past 11, 449-471.

Anderson, P.M., Brubaker, L.B., 1994. Vegetation history of northcentral Alaska: a mapped summary of late-Quaternary pollen data. Quaternary Science Reviews 13, 71-92.

Anderson, P.M., Reanier, R.E., Brubaker, L.B., 1988. Late Quaternary vegetational history of the Black River region in northeastern Alaska. Canadian Journal of Earth Sciences 25, 84-94.

Antoine, P., Rousseau, D.-D., Fuchs, M., Hatté, C., Gauthier, C., Markovic, S.B., Jovanovic, M., Gaudenyi, T., Moine, O., Rossignol, J., 2009. High-resolution record of the last climatic cycle in the southern Carpathian Basin (Surduk, Vojvodina, Serbia). Quaternary International 198, 19-36.

Auclair, M., Lamothe, M., Lagroix, F., Banerjee, S.K., 2007. Luminescence investigation of loess and tephra from Halfway House section, Central Alaska. Quaternary Geochronology 2, 34-38.

Baker, R.G., Waln, K.A., 1985. Quaternary pollen records from the Great Plains and central United States. In: Bryant, V.M., Jr., Holloway, R.G. (Eds.), Pollen Records of Late-Quaternary North 
American Sediments. American Association of Stratigraphic Palynologists Foundation, Dallas, TX, pp. 191-203.

Barry, R.G., 1992. Mountain Weather and Climate. Routledge, London.

Begét, J., 1990. Middle Wisconsinan climate fluctuations recorded in central Alaskan loess. Géographie Physique et Quaternaire 44, 3-13.

Begét, J., Edwards, M., Hopkins, D., Keskinen, M., Kukla, G., 1991. Old Crow tephra found at the Palisades of the Yukon, Alaska. Quaternary Research 35, 291-297.

Berger, A., Loutre, M.F., 1991. Insolation values for the climate of the last 10 million years. Quaternary Science Reviews 10, 297-317.

Berger, G.W., 2003. Luminescence chronology of late Pleistocene loess-paleosol and tephra sequences near Fairbanks, Alaska. Quaternary Research 60, 70-83.

Bettis, E.A., III, Muhs, D.R., Roberts, H.M., Wintle, A.G., 2003. Last glacial loess in the conterminous USA. Quaternary Science Reviews 22, 1907-1946.

Bigelow, N.H., Edwards, M.E., 2001. A 14,000 yr paleoenvironmental record from Windmill Lake, central Alaska: Lateglacial and Holocene vegetation in the Alaska Range. Quaternary Science Reviews 20, 203-215.

Bigelow, N.H., Brubaker, L.B., Edwards, M.E., Harrison, S.P., Prentice, I.C., Anderson, P.M., Andreev, A.A., et al., 2003. Climate change and Arctic ecosystems: 1. Vegetation changes north of $55^{\circ} \mathrm{N}$ between the last glacial maximum, mid-Holocene, and present. Journal of Geophysical Research: Atmospheres 108, 8170. http://dx.doi.org/10.1029/2002JD002558.

Birkeland, P.W., 1999. Soils and Geomorphology. Oxford University Press, New York.

Briner, J.P., Kaufman, D.S., 2008. Late Pleistocene mountain glaciation in Alaska: key chronologies. Journal of Quaternary Science 23, 659-670.

Brown, J., Ferrians, O.J. Jr., Heginbottom, J.A., Melnikov, E.S., 1997. Circum-Arctic Map of Permafrost and Ground-Ice Conditions. U.S. Geological Survey (USGS) Map CP-45, scale 1:10,000,000. USGS, Denver, CO.

Budahn, J.R., Wandless, G.A., 2002. Instrumental neutron activation by long count. In: Taggart, J.E., Jr. (Ed.), Analytical Methods for Chemical Analysis of Geologic and Other Materials. U.S. Geological Survey (USGS) Open-File Report 02-223. USGS, Denver, CO, pp. X-1-X-13.

Carlson, L.J., Finney, B.P., 2004. A 130 0-year history of vegetation and environmental change at Jan Lake, east-central Alaska. The Holocene 14, 818-827.

DiPietro, L.M., Driese, S.G., Nelson, T.W., Harvill, J.L., 2017. Variations in late Quaternary wind intensity from grain-size partitioning of loess deposits in the Nenana River Valley, Alaska. Quaternary Research 87, 258-274.

Dreimanis, A., 1962. Quantitative gasometric determination of calcite and dolomite by using Chittick apparatus. Journal of Sedimentary Petrology 32, 520-529.

Dyke, A.S., Andrews, J.T., Clark, P.U., England, J.H., Miller, G.H., Shaw, J., Veillette, J.J., 2002. The Laurentide and Innuitian ice sheets during the Last Glacial Maximum. Quaternary Science Reviews 21, 9-31.

Eberl, D.D., 2004. Quantitative mineralogy of the Yukon River system: changes with reach and season, and determining sediment provenance. American Mineralogist 89, 1784-1794.

Edwards, M.E., Barker, E.D. Jr., 1994. Climate and vegetation in northeastern Alaska 18,000 yr B.P.-present. Palaeogeography, Palaeoclimatology, Palaeoecology 109, 127-135.
Edwards, M.E., Brubaker, L.B., 1986. Late Quaternary vegetation history of the Fishhook Bend area, Porcupine River, Alaska. Canadian Journal of Earth Sciences 23, 1765-1773.

Edwards, M.E., Anderson, P.M., Brubaker, L.B., Ager, T.A., Andreev, A.A., Bigelow, N.H., Cwynar, L.C., et al., 2000. Pollen-based biomes for Beringia 18,000, 6000 and $0{ }^{14} \mathrm{C}$ yr BP. Journal of Biogeography 27, 521-554.

Edwards, M.E., Grosse, G., Jones, B.M., McDowell, P., 2016. The evolution of a thermokarst-lake landscape: Late Quaternary permafrost degradation and stabilization in interior Alaska. Sedimentary Geology 340, 3-14.

Edwards, M.E., Mock, C.J., Finney, B.P., Barber, V.A., Bartlein, P.J., 2001. Potential analogues for paleoclimatic variations in eastern interior Alaska during the past 14,000 yr: atmospheric-circulation controls of regional temperature and moisture responses. Quaternary Science Reviews 20, 189-202.

Foster, H.L., Laird, J., Keith, T.E.C., Cushing, G.W., Menzie, D.W., 1983. Preliminary Geologic Map of the Circle Quadrangle, Alaska. U.S. Geological Survey (USGS) Open-File Report 83170-A, scale, 1:250,000. USGS, Menlo Park, CA.

Froese, D., Westgate, J., Preece, S., Storer, J., 2002. Age and significance of the late Pleistocene Dawson tephra in eastern Beringia. Quaternary Science Reviews 21, 2137-2142.

Froese, D.G., Smith, D.G., Clement, D.T., 2005. Characterizing large river history with shallow geophysics: middle Yukon River, Yukon Territory and Alaska. Geomorphology 67, 391-406.

Froese, D.G., Zazula, G.D., Reyes, A.V., 2006. Seasonality of the late Pleistocene Dawson tephra and exceptional preservation of a buried riparian surface in central Yukon Territory, Canada. Quaternary Science Reviews 25, 1542-1551.

Grimley, D.A., Follmer, L.R., McKay, E.D., 1998. Magnetic susceptibility and mineral zonations controlled by provenance in loess along the Illinois and central Mississippi River valleys. Quaternary Research 49, 24-36.

Guthrie, R.D., 1990. Frozen Fauna of the Mammoth Steppe: The Story of Blue Babe. University of Chicago Press, Chicago.

Hamilton, T.D., 1982. A late Pleistocene glacial chronology for the southern Brooks Range: stratigraphic record and regional significance. Geological Society of America Bulletin 93, 700-716.

Hamilton, T.D., Craig, J.L., Sellmann, P.V., 1988. The Fox permafrost tunnel: a late Quaternary geologic record in central Alaska. Geological Society of America Bulletin 100, 948-969.

Höfle, C., Edwards, M.E., Hopkins, D.M., Mann, D.H., 2000. The full-glacial environment of the northern Seward Peninsula, Alaska, reconstructed from the 21,500-year-old Kitluk paleosol. Quaternary Research 53, 143-153.

Höfle, C., Ping, C.-L., 1996. Properties and soil development of latePleistocene paleosols from Seward Peninsula, northwest Alaska. Geoderma 71, 219-243.

Hopkins, D.M., 1963. Geology of the Imuruk Lake Area, Seward Peninsula, Alaska. U.S. Geological Survey (USGS) Bulletin 1141-C. U.S. Government Printing Office, Washington, DC.

Hopkins, D.M., 1982. Aspects of the paleogeography of Beringia during the late Pleistocene. In: Hopkins, D.M., Matthews, J.V., Jr., Schweger, C.E., Young, S.B. (Eds.), Paleoecology of Beringia. Academic Press, New York, pp. 3-28.

Jensen, B., Froese, D., Preece, S., Westgate, J., Stachel, T., 2008. An extensive middle to late Pleistocene tephrochronologic record from east-central Alaska. Quaternary Science Reviews 27, 411-427. 
Jensen, B.J.L., Evans, M.E., Froese, D.G., Kravchinsky, V.A., 2016. 150,000 Years of loess accumulation in central Alaska. Quaternary Science Reviews 135, 1-23.

Jensen, B.J.L., Preece, S.J., Lamothe, M., Pearce, N.J.G., Froese, D.G., Westgate, J.A., Schaefer, J., Begét, J., 2011. The variegated (VT) tephra: a new regional marker for middle to late marine isotope stage 5 across Yukon and Alaska. Quaternary International 246, 312-323.

Jensen, B.J.L., Reyes, A.V., Froese, D.G., Stone, D.B., 2013. The Palisades is a key reference site for the middle Pleistocene of eastern Beringia: new evidence from paleomagnetics and regional tephrostratigraphy. Quaternary Science Reviews 63, 91-108.

Kaufman, D.S., Manley, W.F., Ager, T.A., Axford, Y., Balascio, N.L., Begét, J.E., Brigham-Grette, J., et al., 2004. Pleistocene maximum and late Wisconsinan glacier extents across Alaska, U.S.A. In: Ehlers, J., Gibbard, P.L. (Eds.), Quaternary Glaciations-Extent and Chronology, Part II. Developments in Quaternary Science 2. Elsevier, Amsterdam, pp. 9-27.

Lamb, H.F., Edwards, M.E., 1988. The Arctic. In: Huntley, B., Webb, T., III (Eds.), Vegetation History. Kluwer Academic, Dordrecht, the Netherlands, pp. 519-555.

Lea, P.D., Waythomas, C.F., 1990. Late-Pleistocene eolian sand sheets in Alaska. Quaternary Research 34, 269-281.

Machalett, B., Oches, E.A., Frechen, M., Zöller, L., Hambach, U., Mavlyanova, N.G., Markovic, S.B., Endlicher, W., 2008. Aeolian dust dynamics in central Asia during the Pleistocene: driven by the long-term migration, seasonality, and permanency of the Asiatic polar front. Geochemistry, Geophysics, Geosystems 9, Q08Q09. http://dx.doi.org/10.1029/2007GC001938.

Martinson, D.G., Pisias, N.G., Hays, J.D., Imbrie, J., Moore, T.C. Jr., Shackleton, N.J., 1987. Age dating and the orbital theory of the ice ages: development of a high-resolution 0 to 300,000-year chronostratigraphy. Quaternary Research 27, 1-29.

Matheus, P., Begét, J., Mason, O., Gelvin-Reymiller, C., 2003. Late Pliocene to late Pleistocene environments preserved at the Palisades site, Yukon River, Alaska. Quaternary Research 60, 33-43.

McDowell, P.F., Edwards, M.E., 2001. Evidence of Quaternary climatic variations in a sequence of loess and related deposits at Birch Creek, Alaska: implications for the Stage 5 climatic chronology. Quaternary Science Reviews 20, 63-76.

McGeehin, J., Burr, G.S., Jull, A.J.T., Reines, D., Gosse, J., Davis, P.T., Muhs, D., Southon, J.R., 2001. Stepped-combustion ${ }^{14} \mathrm{C}$ dating of sediment: a comparison with established techniques. Radiocarbon 43, 255-261.

McLennan, S.M., 1989. Rare earth elements in sedimentary rocks: influence of provenance and sedimentary processes. Reviews in Mineralogy 21, 169-200.

Moore, D.M., Reynolds, R.C. Jr., 1989. X-ray Diffraction and the Identification and Analysis of Clay Minerals. Oxford University Press, Oxford.

Muhs, D.R., 2013. Loess and its geomorphic, stratigraphic, and paleoclimatic significance in the Quaternary. In: Lancaster, N., Sherman, D.J., Baas, A.C.W. (Eds.), Treatise on Geomorphology Vol. 11, Aeolian Geomorphology, Academic Press, San Diego, CA, pp. 149-183.

Muhs, D.R., Ager, T.A., Been, J., Bradbury, J.P., Dean, W.E., 2003a. A late Quaternary record of eolian silt deposition in a maar lake, St. Michael Island, western Alaska. Quaternary Research 60, 110-122.

Muhs, D.R., Ager, T.A., Been, J.M., Rosenbaum, J.G., Reynolds, R.L., 2000. An evaluation of methods for identifying and interpreting buried soils in late Quaternary loess in Alaska. U.S. Geological Survey Professional Paper 1615, 127-146.

Muhs, D.R., Ager, T.A., Bettis, E.A. III, McGeehin, J., Been, J.M., Begét, J.E., Pavich, M.J., Stafford, T.W. Jr., Stevens, D.S.P., 2003b. Stratigraphy and paleoclimatic significance of late Quaternary loess-paleosol sequences of the last interglacialglacial cycle in central Alaska. Quaternary Science Reviews 22, 1947-1986.

Muhs, D.R., Ager, T.A., Skipp, G., Beann, J., Budahn, J.R., McGeehin, J.P., 2008a. Paleoclimatic significance of chemical weathering in loess-derived paleosols of subarctic central Alaska. Arctic, Antarctic, and Alpine Research 40, 396-411.

Muhs, D.R., Bettis, E.A., III, 2000. Geochemical variations in Peoria Loess of western Iowa indicate paleowinds of midcontinental North America during last glaciation. Quaternary Research 53, 49-61.

Muhs, D.R., Bettis, E.A., III, Aleinikoff, J., McGeehin, J.P., Beann, J., Skipp, G., Marshall, B.D., Roberts, H.M., Johnson, W.C., Benton, R., 2008b. Origin and paleoclimatic significance of late Quaternary loess in Nebraska: evidence from stratigraphy, chronology, sedimentology, and geochemistry. Geological Society of America Bulletin 120, 1378-1407.

Muhs, D.R., Bettis, E.A., III, Roberts, H.M., Harlan, S., Paces, J.B., Reynolds, R., 2013a. Chronology and provenance of last-glacial (Peoria) loess in western Iowa and paleoclimatic implications. Quaternary Research 80, 468-481.

Muhs, D.R., Budahn, J.R., 2006. Geochemical evidence for the origin of late Quaternary loess in central Alaska. Canadian Journal of Earth Sciences 43, 323-337.

Muhs, D.R., Budahn, J.R., McGeehin, J.P., Bettis, E.A., III, Skipp, G., Paces, J.B., Wheeler, E.A., 2013b. Loess origin, transport, and deposition over the past 10,000 years, Wrangell-St. Elias National Park, Alaska. Aeolian Research 11, 85-99.

Muhs, D.R., Budahn, J.R., Skipp, G.L., McGeehin, J.P., 2016a. Geochemical evidence for seasonal controls on the transportation of Holocene loess, Matanuska Valley, southern Alaska, USA. Aeolian Research 21, 61-73.

Muhs, D.R., Lancaster, N., Skipp, G.L., 2016b. A complex origin for the Kelso Dunes, Mojave National Preserve, California USA: a case study using a simple geochemical method with global applications. Geomorphology 276, 222-243.

Muhs, D.R., McGeehin, J.P., Beann, J., Fisher, E., 2004. Holocene loess deposition and soil formation as competing processes, Matanuska Valley, southern Alaska. Quaternary Research 61, 265-276.

Oches, E.A., Banerjee, S.K., Solheid, P.A., Frechen, M., 1998. High resolution proxies of climate variability in the Alaskan loess record. In: Busacca, A.J. (Ed.), Dust Aerosols, Loess Soils and Global Change. Miscellaneous Publication No. MISC0190. Washington State University, College of Agriculture and Home Economics, Pullman, pp. 167-170.

Onishi, H., Sandell, E.B., 1955. Geochemistry of arsenic. Geochimica et Cosmochimica Acta 7, 1-33.

Péwé, T.L., 1975a. Quaternary Geology of Alaska. U.S. Geological Survey (USGS) Professional Paper 835. U.S. Government Printing Office, Washington, DC.

Péwé, T.L., 1975b. Quaternary Stratigraphic Nomenclature in Unglaciated Central Alaska. U.S. Geological Survey (USGS) Professional Paper 862. U.S. Government Printing Office, Washington, DC.

Péwé, T.L., Wahrhaftig, C., Weber, F.R., 1966. Geologic Map of the Fairbanks Quadrangle, Alaska. U.S. Geological Survey (USGS) 
Miscellaneous Investigations Map I-455, scale 1:250,000. USGS, Reston, VA.

Pigati, J.S., McGeehin, J.P., Muhs, D.R., Bettis, E.A., III, 2013. Radiocarbon dating late Quaternary loess deposits using small terrestrial gastropods. Quaternary Science Reviews 76, 114-128.

Pigati, J.S., McGeehin, J.P., Muhs, D.R., Grimley, D.C., Nekola, J.C., 2015. Radiocarbon dating loess deposits in the Mississippi Valley using terrestrial gastropod shells (Polygyridae, Helicinidae, Discidae). Aeolian Research 16, 25-33.

Pigati, J.S., Rech, J.A., Nekola, J.C., 2010. Radiocarbon dating of small terrestrial gastropod shells in North America. Quaternary Geochronology 5, 519-532.

Pilsbry, H.A., 1948. Land Mollusca of North America (North of Mexico). Vol. 2, Part 2. Academy of Natural Sciences of Philadelphia Monographs, 3. Academy of Natural Sciences, Philadelphia, PA.

Preece, S.J., Pearce, N.J.G., Westgate, J.A., Froese, D.G., Jensen, B.J.L., Perkins, W.T., 2011. Old Crow tephra across eastern Beringia: a single cataclysmic eruption at the close of Marine Isotope Stage 6. Quaternary Science Reviews 30, 2069-2090.

Preece, S.J., Westgate, J.A., Gorton, M.P., 1992. Compositional variation and provenance of late Cenozoic distal tephra beds, Fairbanks area. Alaska. Quaternary International 13/14, 97-101.

Preece, S.J., Westgate, J.A., Stemper, B.A., Péwé, T.L., 1999. Tephrochronology of late Cenozoic loess at Fairbanks, central Alaska. Geological Society of America Bulletin 111, 71-90.

Reger, R.D., Pinney, D.S., Burke, R.M., Wiltse, M.A., 1996. Catalog and Initial Analyses of Geologic Data Related to Middle to Late Quaternary Deposits, Cook Inlet Region, Alaska. Report of Investigations 95-6. State of Alaska, Department of Natural Resources, Division of Geological and Geophysical Surveys, Fairbanks, AK.

Reimer, P.J., Bard, E., Bayliss, A., Beck, J.W., Blackwell, P.G., Bronk Ramsey, C., Grootes, P.M., et al., 2013. IntCal13 and Marine13 radiocarbon age calibration curves 0-50,000 years cal BP. Radiocarbon 55, 1869-1887.

Reyes, A.V., Froese, D.G., Jensen, B.J.L., 2010a. Permafrost response to last interglacial warming: field evidence from nonglaciated Yukon and Alaska. Quaternary Science Reviews 29, 3256-3274.

Reyes, A.V., Jensen, B.J.L., Zazula, G.D., Ager, T.A., Kuzmina, S., La Farge, C., Froese, D.G., 2010b. A late-Middle Pleistocene (Marine Isotope Stage 6) vegetated surface buried by Old Crow tephra at the Palisades, interior Alaska. Quaternary Science Reviews 29, 801-811.

Reyes, A.V., Zazula, G.D., Kuzmina, S., Ager, T.A., Froese, D.G., 2011. Identification of last interglacial deposits in eastern Beringia: a cautionary note from the Palisades, interior Alaska. Journal of Quaternary Science 26, 345-352.

Roberts, H.M., 2012. Testing post-IR IRSL protocols for minimising fading in feldspars, using Alaskan loess with independent chronological control. Radiation Measurements 47, 716-724.

Roberts, H.M., Muhs, D.R., Wintle, A.G., Duller, G.A.T., Bettis, E.A. III, 2003. Unprecedented last-glacial mass accumulation rates determined by luminescence dating of loess from western Nebraska. Quaternary Research 59, 411-419.

Rousseau, D.-D., Sima, A., Antoine, P., Hatté, C., Lang, A., Zöller, L., 2007. Link between European and North Atlantic abrupt climate changes over the last glaciation. Geophysical
Research Letters 34, L22713. http://dx.doi.org/10.1029/2007 GL031716.

Sainsbury, C.L., 1972. Geologic Map of the Teller Quadrangle, Western Seward Peninsula, Alaska. U.S. Geological Survey (USGS) Miscellaneous Geologic Investigations Map I-685, scale 1:250,000. USGS, Reston, VA.

Schaetzl, R.J., Attig, J.W., 2013. The loess cover of northeastern Wisconsin. Quaternary Research 79, 199-214.

Schoeneberger, P.J., Wysocki, D.A., Benham, E.C., Soil Survey Staff. 2012. Field Book for Describing and Sampling Soils, Version 3.0. U.S. Department of Agriculture, Natural Resources Conservation Service, National Soil Survey Center, Lincoln, NE.

Stuiver, M., Reimer, P.J., 1993. Extended ${ }^{14} \mathrm{C}$ database and revised CALIB radiocarbon calibration program. Radiocarbon 35, 215-230.

Taylor, S.R., McLennan, S.M., 1985. The Continental Crust: Its Composition and Evolution. Blackwell Scientific, Oxford, UK.

Thorson, R.M., Bender, G., 1985. Eolian deflation by ancient katabatic winds: a late Quaternary example from the north Alaska Range. Geological Society of America Bulletin 96, 702-709.

Tinner, W., Hu, F.S., Beer, R., Kaltenrieder, P., Scheurer, B., Krähenbühl, U., 2006. Postglacial vegetational and fire history: pollen, plant macrofossil and charcoal records from two Alaskan lakes. Vegetation History and Archaeobotany 15, 279-293.

Tsoar, H., Pye, K., 1987. Dust transport and the question of desert loess formation. Sedimentology 34, 139-153.

Weber, F.R., Wheeler, K.L., Rinehart, C.D., Light, T.D., 1997. Generalized Geologic Map of the Livengood Quadrangle, Alaska. U.S. Geological Survey (USGS) Open-File Report 97-484-A, scale, 1:250,000. USGS, Menlo Park, CA.

Wells, P.V., Stewart, J.D., 1987. Spruce charcoal, conifer macrofossils, and landsnail and small-vertebrate faunas in Wisconsinan sediments on the High Plains of Kansas. In: Johnson, W.C. (Ed.), Quaternary Environments of Kansas. Kansas Geological Survey Guidebook Series 5. Kansas Geological Survey, Lawrence, KS, pp. 129-140.

Westgate, J., 1988. Isothermal plateau fission-track age of the late Pleistocene Old Crow tephra, Alaska. Geophysical Research Letters 15, 376-379.

Westgate, J.A., Stemper, B.A., Péwé, T.L., 1990. A 3 m.y. record of Pliocene-Pleistocene loess in interior Alaska. Geology 18, 858-861.

White, J.D., Koepke, B.E., Swanson, D.K., 2000. Soil Survey of North Star Area, Alaska. U.S. Department of Agriculture, Natural Resources Conservation Service, Washington, DC.

Williams, J.R., 1962. Geologic Reconnaissance of the Yukon Flats District, Alaska. U.S. Geological Survey (USGS) Bulletin 1111-H. U.S. Government Printing Office, Washington, DC, pp. H289-H331.

Zazula, G.D., Froese, D.G., Westgate, J.A., La Farge, C., Mathewes, R.W., 2005. Paleoecology of Beringian "packrat" middens from central Yukon Territory, Canada. Quaternary Research 63, 189-198.

Zazula, G.D., Schweger, C.E., Beaudoin, A.B., McCourt, G.H., 2006. Macrofossil and pollen evidence for full-glacial steppe within an ecological mosaic along the Bluefish River, eastern Beringia. Quaternary International 142-143, 2-19. 
Table S1-Character of seismic-stratigraphic units

\begin{tabular}{|c|c|c|}
\hline & & Seismic Unit A \\
\hline \multirow[t]{2}{*}{$\begin{array}{l}\text { Reflection } \\
\text { Character }\end{array}$} & Amplitude & $\begin{array}{l}\text { Generally high with higher amplitudes at the margins of the basin and } \\
\text { lower in the middle. Signal tends to diminish rapidly with depth below } \\
\text { the upper boundary. }\end{array}$ \\
\hline & Continuity & $\begin{array}{l}\text { High to moderate though occasional discontinuities exist. Reflections } \\
\text { are obscured by shallow gas or noise in Buffalo and Sabaskong Bays. }\end{array}$ \\
\hline \multicolumn{2}{|c|}{$\begin{array}{l}\text { Reflection } \\
\text { Configuration }\end{array}$} & $\begin{array}{l}\text { Occasionally stratified sub-parallel or uneven parallel where penetration } \\
\text { occurs beneath upper boundary. Upper boundary itself is very irregular } \\
\text { in shape, displaying relatively high topographic relief in the middle part } \\
\text { of the basin and smoothed surfaces at the margins of the basin. No } \\
\text { stratification occurs where the configuration is smooth. }\end{array}$ \\
\hline \multicolumn{2}{|c|}{$\begin{array}{l}\text { External } \\
\text { Geometry }\end{array}$} & $\begin{array}{l}\text { The upper surface of this unit forms the acoustic basement in most areas } \\
\text { and the unit is observed everywhere within the survey area with the } \\
\text { exception of gassy regions. It is deepest in the middle of Big Traverse } \\
\text { Bay and shallowest near Garden Island marking the separation of Big } \\
\text { Traverse Bay and Little Traverse Bay. Local variations in depth are } \\
\text { observed across the survey area with some occurring abruptly. }\end{array}$ \\
\hline
\end{tabular}

\begin{tabular}{|c|c|c|}
\hline & & Seismic Unit B \\
\hline \multirow{3}{*}{$\begin{array}{l}\text { Reflection } \\
\text { Character }\end{array}$} & & Low to moderate amplitudes. \\
\hline & Amplitude & \\
\hline & Continuity & $\begin{array}{l}\text { Internal reflections are mostly discontinuous but occasionally are } \\
\text { laterally continuous for several kilometers near the margins of the } \\
\text { basin. Much of this unit is obscured by shallow gas or background noise } \\
\text { outside of Big Traverse Bay. }\end{array}$ \\
\hline \multicolumn{2}{|c|}{$\begin{array}{c}\text { Reflection } \\
\text { Configuration }\end{array}$} & $\begin{array}{l}\text { Nearly reflection-free but weakly stratified wavy parallel in some areas. } \\
\text { The upper part of the unit is concordant with Unconformity } 1 \text { in the } \\
\text { middle of the basin but is truncated by Unconformities } 1,2 \text {, or } 3 \text { near or } \\
\text { at the margins of the basin. }\end{array}$ \\
\hline \multicolumn{2}{|c|}{$\begin{array}{l}\text { External } \\
\text { Geometry }\end{array}$} & $\begin{array}{l}\text { Seismic Unit B is observed mostly in the central part of Big Traverse } \\
\text { Bay where it is not obscured by noise or gas. It displays a sheet drape } \\
\text { geometry over Unit A and is spatially uniform in thickness where not } \\
\text { truncated by Unconformities } 1,2 \text {, or } 3 \text {. It is thinnest near Long Point } \\
\text { and in the northwest part of Big Traverse Bay. }\end{array}$ \\
\hline
\end{tabular}

\begin{tabular}{|c|c|c|}
\hline & & Seismic Unit C \\
\hline \multirow[t]{2}{*}{$\begin{array}{l}\text { Reflection } \\
\text { Character }\end{array}$} & Amplitude & $\begin{array}{l}\text { High to moderate, though, some low-amplitude reflectors are visible in } \\
\text { the center of the seismic unit. A few high-amplitude reflections are } \\
\text { sandwiched between low-amplitude and reflection free zones. }\end{array}$ \\
\hline & Continuity & $\begin{array}{l}\text { Moderate to highly continuous. Some reflections are discontinuous in } \\
\text { the center of the seismic unit and occur where the seismic signal is } \\
\text { "wiped- out". Much of this unit is obscured by shallow gas or } \\
\text { background noise outside of Big Traverse Bay. }\end{array}$ \\
\hline \multicolumn{2}{|c|}{$\begin{array}{c}\text { Reflection } \\
\text { Configuration }\end{array}$} & $\begin{array}{l}\text { Strongly stratified wavy parallel with regions that are reflection-free to } \\
\text { faintly stratified. Internal reflectors frequently onlap onto Unconformity } \\
1 \text { and are ponded at topographic lows. Seismic profiles striking NE to } \\
\text { SW display some internal reflections that have a divergent } \\
\text { configuration. The magnitude and direction of divergence varies } \\
\text { vertically in the seismic unit. In the middle of the basin, the upper part } \\
\text { of this seismic unit is concordant with Unconformity } 2 \text {. Near the } \\
\text { margins, however, it is truncated by Unconformities } 2 \text { and } 3 \text { causing } \\
\text { seismic Unit C to pinch out. Reflections become increasingly more } \\
\text { planar moving up the seismic unit. }\end{array}$ \\
\hline
\end{tabular}



configuration), a ponded geometry (onlapping reflections), and a divergent geometry (lateral thickening between high-amplitude reflectors). It is thickest in the center of Big Travers Bay and thins more rapidly to the NE than other direction. It is thinnest where Unconformities 2 and 3 truncate internal reflections, to the north and south of the middle of the basin.

\begin{tabular}{|c|c|c|}
\hline & & Seismic Unit D \\
\hline \multirow[t]{2}{*}{$\begin{array}{l}\text { Reflection } \\
\text { Character }\end{array}$} & Amplitude & $\begin{array}{l}\text { Low to moderate. Reflection amplitudes are highest near } \\
\text { Unconformities } 2 \text { and } 3 \text {. High-amplitude acoustic noise is frequent } \\
\text { directly below Unconformity } 3 \text { and reflections often fade into the } \\
\text { background noise. }\end{array}$ \\
\hline & Continuity & $\begin{array}{l}\text { Mostly continuous, though, some discontinuous reflectors are observed } \\
\text { throughout the seismic unit. Seismic Unit D is sometimes obscured by } \\
\text { shallow gas or background noise (i.e. Buffalo and Sabaskong Bays). }\end{array}$ \\
\hline \multicolumn{2}{|c|}{$\begin{array}{l}\text { Reflection } \\
\text { Configuration }\end{array}$} & $\begin{array}{l}\text { Strongly stratified parallel to sub-parallel. Internal reflections drape } \\
\text { Unconformity } 2 \text { in the middle of the basin and onlap onto } \\
\text { Unconformity } 2 \text { near the margins of the basin. Internal reflections in the } \\
\text { upper part of the unit are truncated by Unconformity } 3 \text { in all survey } \\
\text { lines. This relationship is most pronounced at the margins but internal } \\
\text { reflections are truncated as much as } 8 \mathrm{~km} \text { into the middle of the basin. }\end{array}$ \\
\hline \multicolumn{2}{|c|}{$\begin{array}{l}\text { External } \\
\text { Geometry }\end{array}$} & $\begin{array}{l}\text { Unit D is observed across the majority of the survey area. It is thickest } \\
\text { in the center of Big Traverse Bay and thins radially towards the } \\
\text { modern-day shoreline. This unit mainly lies unconformably over Unit C } \\
\text { but also lies unconformably over Unit B in regions where Unit C } \\
\text { pinches out (margins). It always underlies Unit E unconformably. }\end{array}$ \\
\hline
\end{tabular}

\begin{tabular}{|c|c|c|}
\hline & & Seismic Unit E \\
\hline \multirow[t]{2}{*}{$\begin{array}{l}\text { Reflection } \\
\text { Character }\end{array}$} & Amplitude & $\begin{array}{l}\text { The upper two-thirds of seismic Unit E is mostly reflection-free with } \\
\text { occasional moderate-amplitude reflectors. The lower third contains } \\
\text { high- amplitude noise that increases in strength towards Unconformity } \\
\text { 3. A few high amplitude reflectors are present through the noise. The } \\
\text { upper boundary (i.e., the lake floor) is moderate-amplitude. }\end{array}$ \\
\hline & Continuity & $\begin{array}{l}\text { Internal reflections are mostly discontinuous. A few reflectors in the } \\
\text { lower part of the seismic unit are laterally continuous for tens of } \\
\text { kilometers. Shallow gas is common in this unit, obscuring any } \\
\text { underlying reflections. }\end{array}$ \\
\hline \multicolumn{2}{|c|}{$\begin{array}{c}\text { Reflection } \\
\text { Configuration }\end{array}$} & $\begin{array}{l}\text { Weakly stratified parallel. Low angle internal reflections onlap onto } \\
\text { Unconformity } 3 \text { over tens of kilometers and occur more frequently in } \\
\text { the southern part of the basin. The upper two-thirds of the seismic unit } \\
\text { is mostly reflection-free. The lower third of the unit contains } \\
\text { background noise that increases in thickness towards the middle of the } \\
\text { basin. }\end{array}$ \\
\hline \multicolumn{2}{|c|}{$\begin{array}{l}\text { External } \\
\text { Geometry }\end{array}$} & $\begin{array}{l}\text { Seismic Unit E is the uppermost unit and is observed over the majority } \\
\text { of the survey area when not obscured by shallow gas. It distinctly } \\
\text { increases in thickness from NE to SW within the survey area and the } \\
\text { thicker regions wrap around Long Point. This seismic unit primarily lies } \\
\text { unconformably over seismic Unit D but also lies unconformably over } \\
\text { seismic Units C, B, and A at or near the margins. }\end{array}$ \\
\hline
\end{tabular}




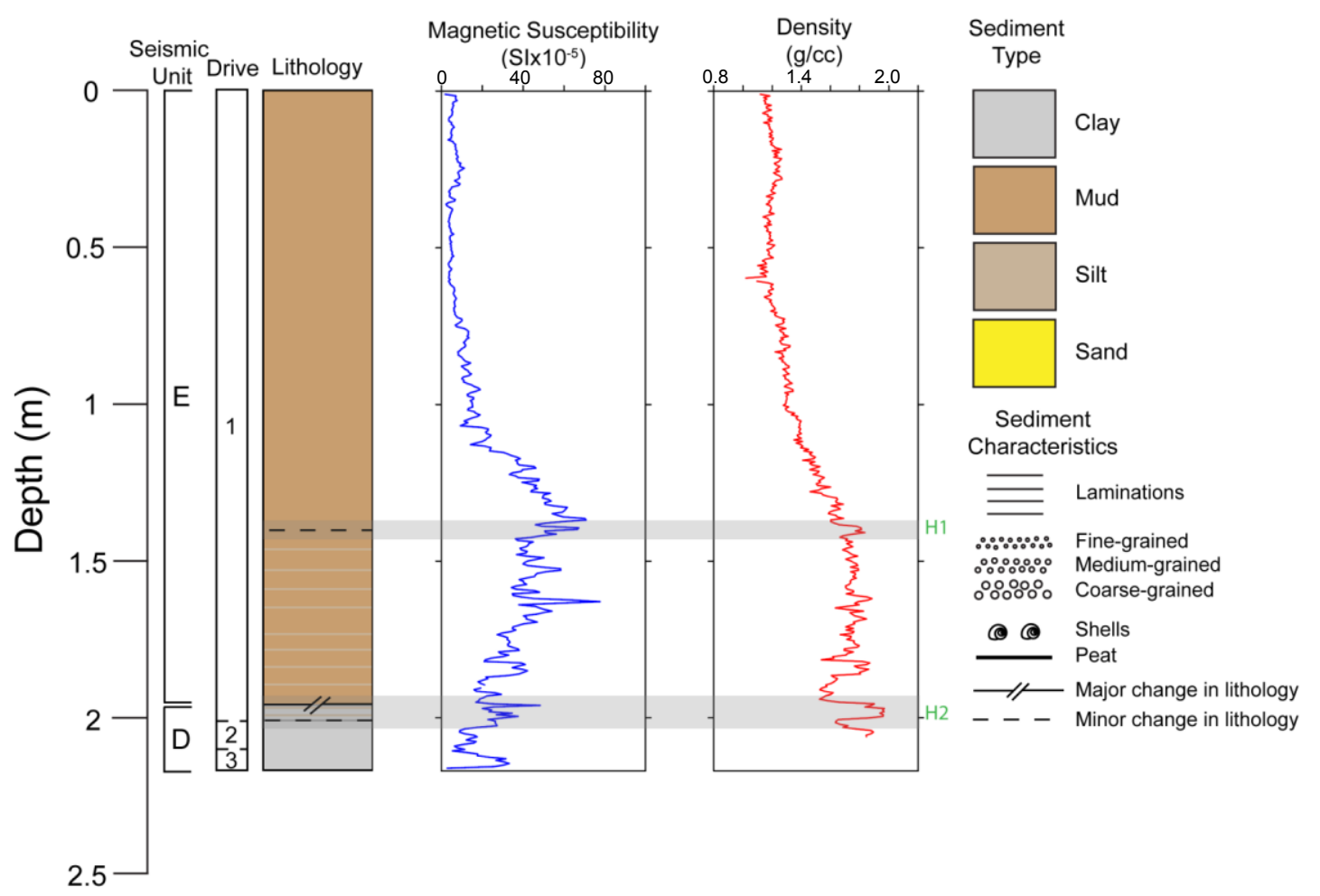

Figure S1. Stratigraphic data for core PALSS-1A; location shown in Fig. 1B. Columns show seismic units, drive length, lithology, magnetic susceptibility, and density data. Gray shaded bars and $\mathrm{H}$ labels represent prominent contrasts in acoustic impedance (reflections) identified from seismic-reflection images over the core site. A major abrupt change in lithology from mud-dominated sediment to clay occurs at a depth of $\sim 2$ $\mathrm{m}(\mathrm{H} 2)$ and corresponds to UNCF-3. 


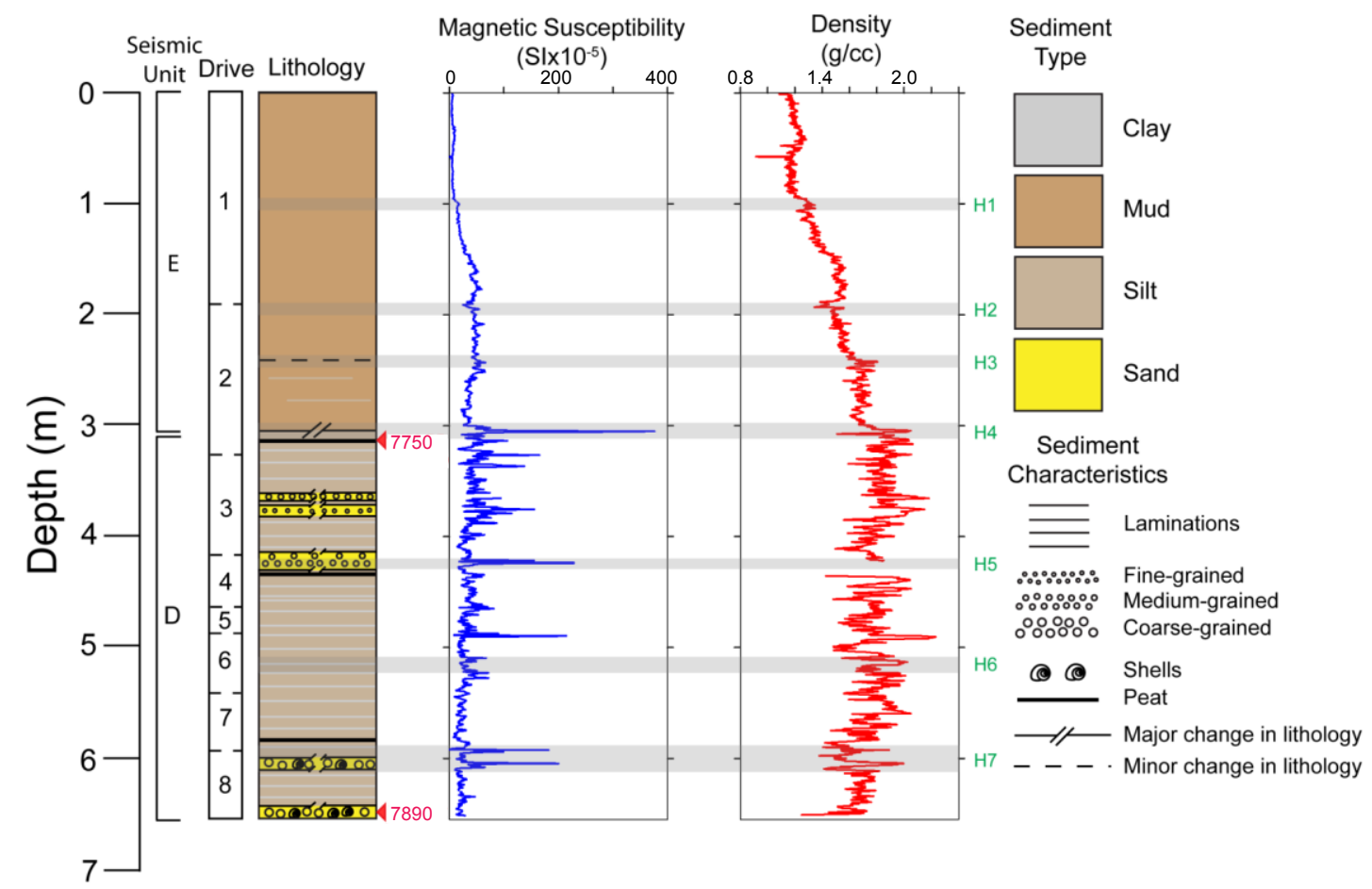

Figure S2. Stratigraphic data for core PALSS-2A; location shown in Fig. 1B. Explanation as in Fig. S1. Triangles and numbers to the right of the lithology column are radiocarbon ages in cal yrs (Table 1). A major abrupt change in lithology from mud-dominated sediment to laminated silt and clay occurs at a depth of $\sim 3$ $\mathrm{m}$ (H4) and corresponds to UNCF-3. Fig. S6 shows the seismic-reflection profile through this core site, along with reflection horizons $\mathrm{H} 1-\mathrm{H} 7$. 


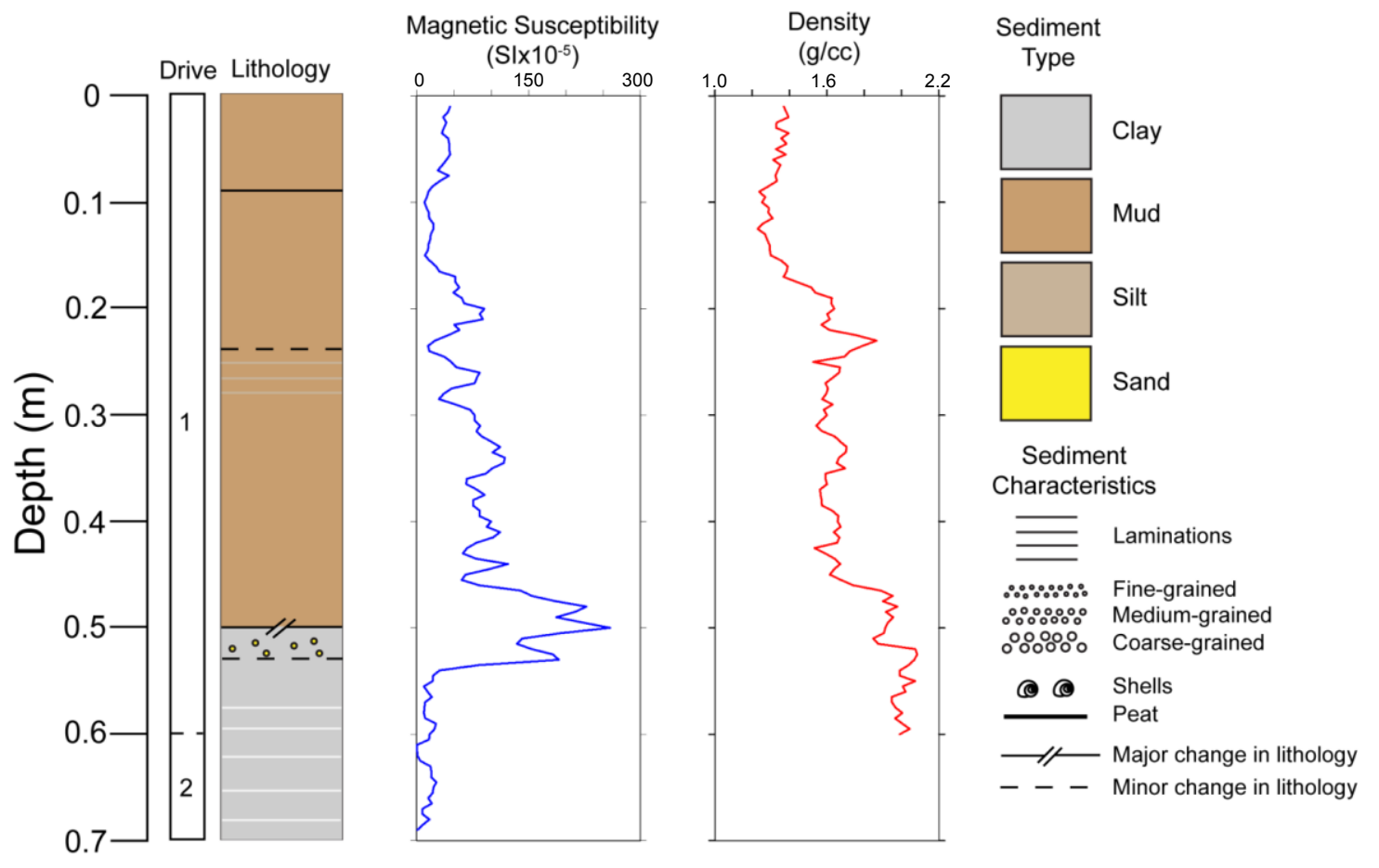

Figure S3. Stratigraphic data for core PALSS-3A; location shown in Fig. 1B. Explanation as in Fig. S1. A major abrupt change in lithology from mud-dominated sediment to sandy clay occurs at a depth of $\sim 0.5 \mathrm{~m}$ (H2) and corresponds to UNCF-3. 


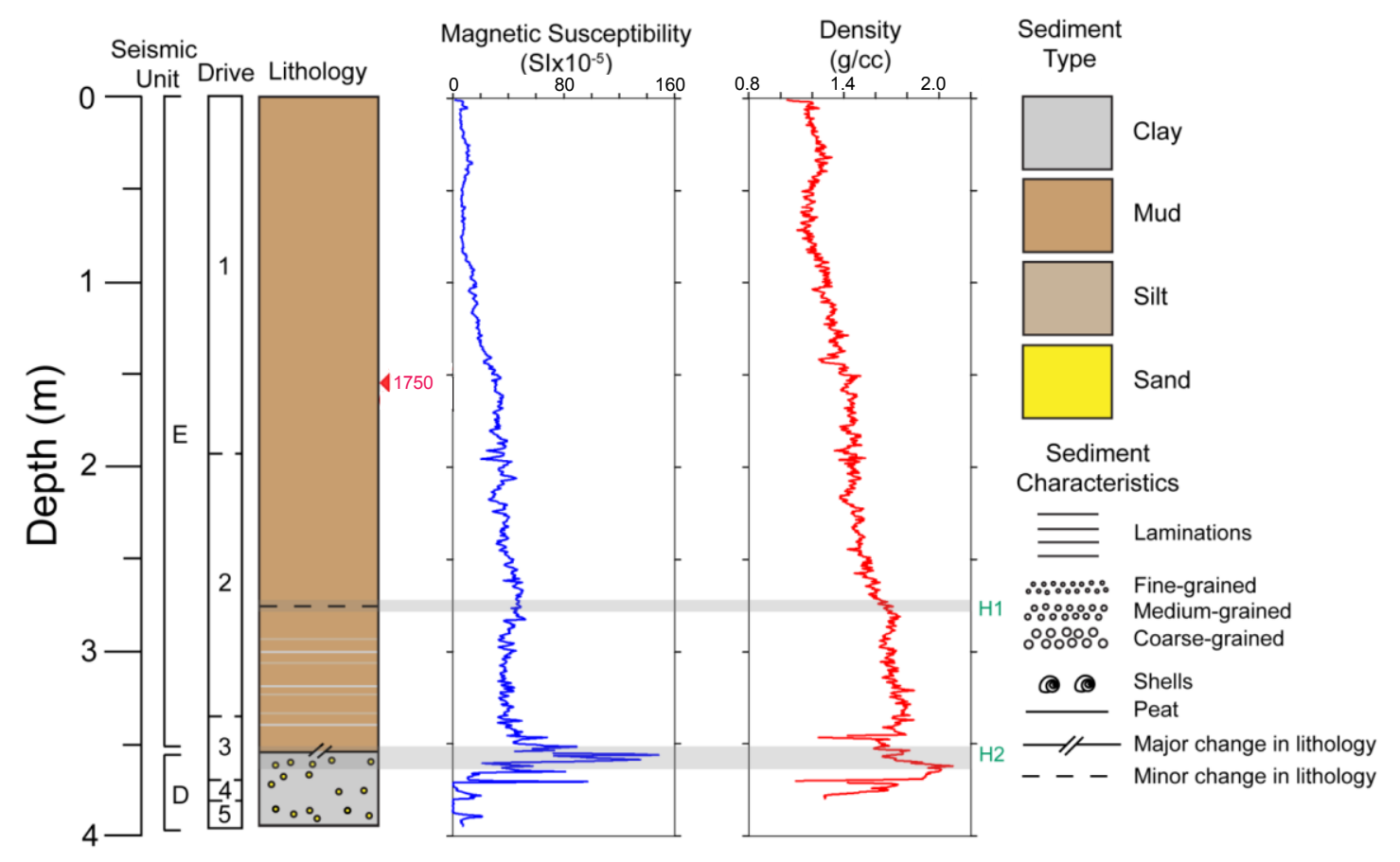

Figure S4. Stratigraphic data for core PALSS-4A; location shown in Fig. 1B. Explanation as in Fig. S1. Triangle and number to the right of the lithology column is radiocarbon age in cal yrs (Table 1). A major abrupt change in lithology from mud-dominated sediment to sandy clay occurs at a depth of $\sim 3.5 \mathrm{~m}$ and corresponds to UNCF-3. 


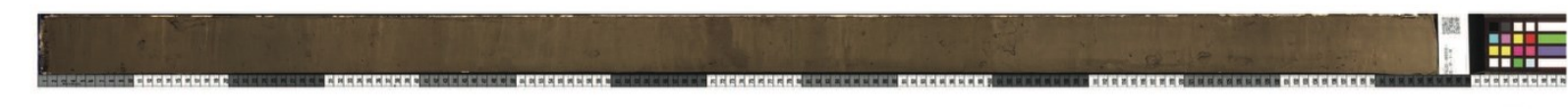

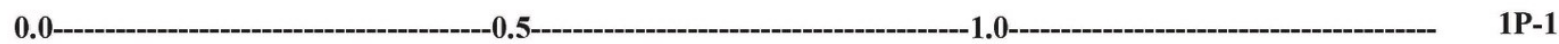
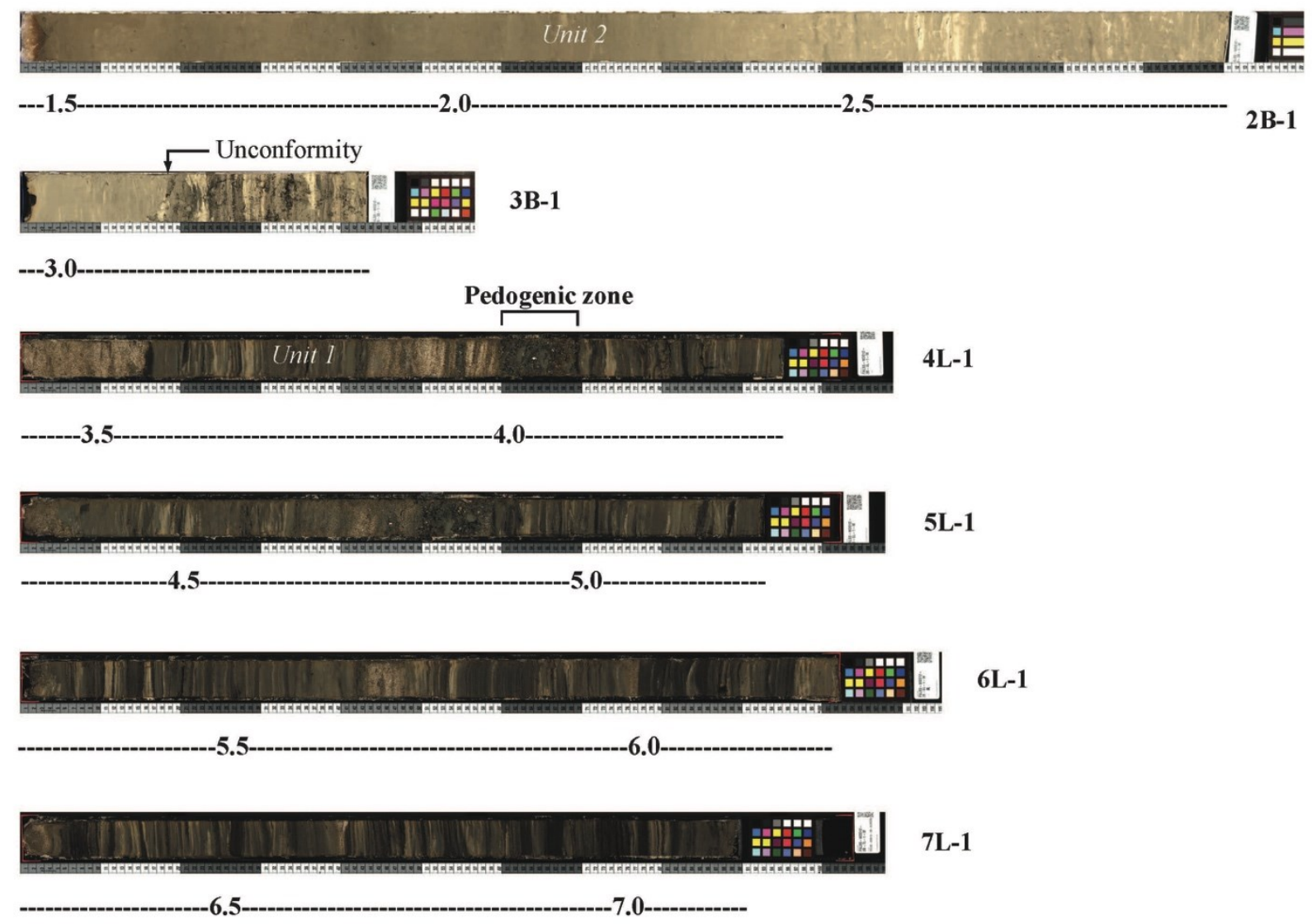

Figure S5. Optical scans of seven segments of core PALSS-2B in the southern basin of LOTW. Top is to left. Location shown in Figure 1B. Numbers along line below core indicate total depth (m); each alternating shaded bar is $10 \mathrm{~cm}$ long. Arrow marks a major unconformity (UNCF-3) that separates Unit SU-D (lower) from Unit SU-E (upper). 


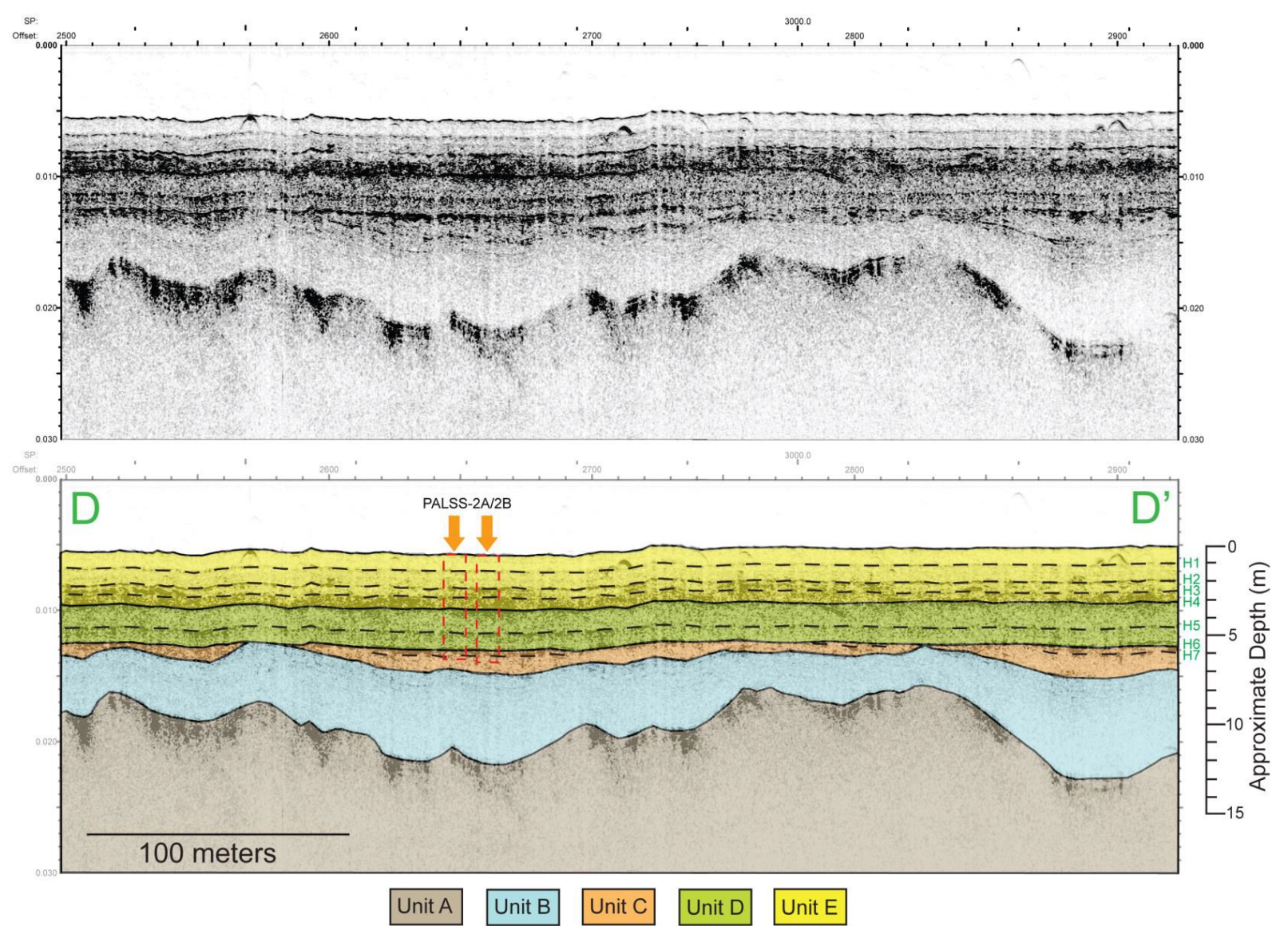

Figure S6. Seismic-reflection profile through core sites PALSS-2A and 2B. Location shown in Figure 1B. Interpreted seismic image (bottom) with the location and lengths of cores PALSS-2A and 2B (dashed red boxes). Seven prominent reflections are labeled (solid and dashed black lines) including UNCF-3 (H4) and UNCF-2 (H6). V.E.: $\sim 9 x$. Fig. S2 shows the core log for core PALSS-2A and Fig. 6 that for PALSS-2B. 